UNIVERSIDADE DE SÃO PAULO

FACULDADE DE DIREITO

\title{
A PUBLICIDADE E SUAS LIMITAÇÕES - A TUTELA DA INTIMIDADE E DO INTERESSE SOCIAL NA PERSECUÇÃO PENAL
}

Dissertação de Mestrado em Direito Processual Penal

Rodrigo MANSOUR MAgalHÃES DA SiLVEIRA

São Paulo, 2010 
A Publicidade e suas Limitações - A Tutela da Intimidade e do Interesse Social na Persecução Penal 
UNIVERSIDADE DE SÃO PAULO

FACULDADE DE DIREITO

\section{A PUBLICIDADE E SUAS LIMITAÇÕES - A TUTELA DA INTIMIDADE E DO INTERESSE SOCIAL NA PERSECUÇÃO PENAL}

Dissertação de Mestrado em Direito Processual Penal apresentada por Rodrigo MANSOUR MAgalHães DA Silveira

Orientador:

Professor Dr. Antonio Magalhães Gomes Filho

São Paulo, 2010 


\section{Agradecimentos}

Agradeço ao Professor Doutor Antonio Magalhães Gomes Filho a oportunidade que me concedeu de ser seu aluno e orientando.

Agradeço ao Professor Doutor Antonio Scarance Fernandes e ao Professor Doutor Gustavo Henrique Righi Ivahy Badaró as inestimáveis sugestões. 


\section{Sumário}

INTRODUÇÃO

\section{A PUBLICIDADE NO QUADRO DAS GARANTIAS DO DEVIDO PROCESSO LEGAL BREVE ANÁLISE HISTÓRICA DA PUBLICIDADE NO PROCESSO PENAL .......................... 5}

1.1. A função do processo penal ...................................... 5

1.2. A busca da verdade e as suas limitações............................. 6

1.3. As garantias processuais ...................................... 9

1.3.1 A imparcialidade do juiz ..................................... 9

1.3.2. O contraditório e a ampla defesa ............................ 10

1.3.3. A legalidade ................................................... 11

1.3.4. A motivação das decisões judiciais ........................... 12

1.3.5. A publicidade e a sua relação com as demais garantias processuais

1.4. Breve análise sobre a evolução histórica da publicidade no processo penal 17

1.4.1. O sistema de civil Law ......................................... 18

1.4.1.1. A antiguidade e o surgimento do processo ............. 18

1.4.1.2. O processo medieval ................................ 20 
1.4.1.3. O iluminismo e sua influência sobre o processo..... 22

1.4.1.4. O sistema misto .......................................... 25

1.4.1.5. A Escola Penal Clássica e a Escola Positiva .......... 25

1.4.2. O sistema de common Law.................................... 27

1.4.3. A evolução da publicidade no Brasil.......................... 28

1.4.3.1. O período colonial .................................... 28

1.4.3.2. O Império ............................................ 29

1.4.3.3. A República................................................ 31

2. A PUBLICIDADE NO PLANO INTERNACIONAL ............. 34

3. A PUBLICIDADE - NOÇÕES CONCEITUAIS ................... 41

3.1. Nota introdutória...................................................... 41

3.2. Publicidade - noções gerais ................................... 41

3.2.1. Publicidade externa e interna............................... 42

3.2.2. Publicidade imediata e mediata .............................. 43

3.2.3. Publicidade plena ou irrestrita e publicidade restrita..... 44

3.3. A publicidade, o sigilo e o segredo ............................. 46

4. A PUBLICIDADENO PLANO CONSTITUCIONAL ............. 48

5. AS INVESTIGAÇÕES CRIMINAIS E A PUBLICIDADE ...... 52 
5.1. A publicidade na fase de investigação

5.2. O inquérito policial e a publicidade 54

5.3. As investigações promovidas pelo Ministério Público e a publicidade

5.4. As investigações legislativas e a publicidade 70

5.5. A limitação da publicidade nas investigações 73

6- O PROCESSO PENAL E A PUBLICIDADE 76

6.1. A publicidade na fase do processo 76

6.2. O artigo 792, caput, e $\S 1^{\circ}$, do Código de Processo Penal.... 77

6.3. O artigo 155 do Código de Processo Civil....................... 80

6.4. A prova testemunhal e a publicidade. 82

6.5. O Tribunal do Júri e a publicidade 83

7- A GARANTia da PUBLICIDAde COMO "PRINCÍPIO E A PROPORCIONALIDADE ........................................... 94

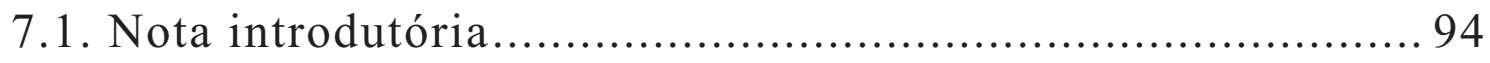

7.2. As modalidades normativas: princípios e regras ................ 94

7.3. A publicidade como "princípio".................................. 96

7.4. A publicidade e o postulado da proporcionalidade............ 105 


\section{8- A LimitaÇÃo da PUBlicidade PARA A Defesa da INTIMIDADE - O DIREITO À INTIMIDADE E A LIBERDADE DE EXPRESSÃO E DE INFORMAÇÃO.............................. 112}

8.1. A proteção dos bens jurídicos de índole pessoal............... 112

8.1.1. O direito à intimidade e à vida privada ................... 113

8.1.2. O direito à imagem....................................... 116

8.1.3. O direito à honra ............................................ 117

8.2. A liberdade de expressão - a liberdade de comunicação ou de informação........................................................... 118

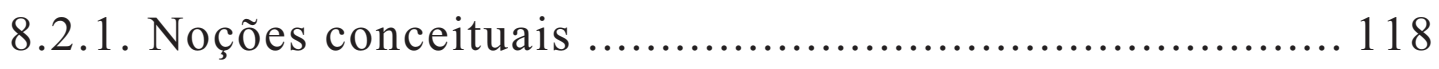

8.2.2. A evolução da tutela das liberdades de expressão e informação no plano internacional 122

8.2.3. A evolução histórica no Brasil da tutela da liberdade de expressão e de informação no plano constitucional ............... 128

8.2.4. Os limites à liberdade de informação ........................ 133

8.3. O confronto entre a intimidade e a liberdade de comunicação, e a sua relação com a garantia da publicidade ...................... 136

8.3.1. A fase investigatória........................................ 136

8.3.2. O processo penal .......................................... 145

9- CONCLUSÕES ................................................... 165 


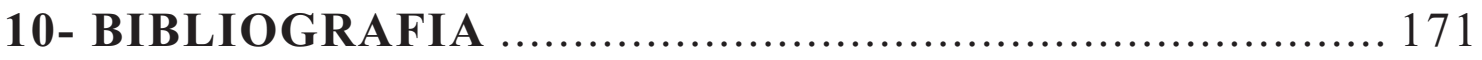

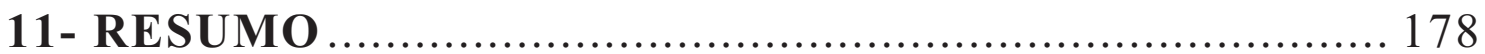

12- RIASSUNTO 


\section{INTRODUÇÃO:}

A garantia da publicidade nas investigações criminais e no processo penal constitui um dos princípios fundamentais do processo penal no Estado Democrático de Direito.

Representa, de um lado, garantia política de que o poder jurisdicional somente será exercido por intermédio de uma persecução penal transparente, na qual a fiscalização ex parte populi preserva o indivíduo contra o arbítrio Estatal, propiciando ainda a verificação sobre a regularidade das posturas adotadas no procedimento e a observância das demais garantias processuais: imparcialidade do julgador, contraditório, ampla defesa, legalidade e motivação das decisões.

A publicidade, vista sob tal aspecto, confere legitimidade à decisão proferida no processo, o que se mostra imprescindível ao exercício do poder no Estado Democrático de Direito, especialmente no que se refere às funções afetas aos órgãos incumbidos da persecução penal e ao Poder Judiciário, que, em regra, não são desempenhadas por agentes escolhidos mediante intervenção popular.

De outro lado, a publicidade também exerce o papel de garantia na persecução penal, viabilizando a atuação de outras garantias, por intermédio do acesso irrestrito às partes, procuradores e juiz a todas as informações constantes dos autos, assim propiciando sobretudo um contraditório pleno e o exercício da ampla defesa. 
É certo, outrossim, que o tema da publicidade na persecução vem, nos dias atuais, ganhando especial relevância.

Com efeito, a evolução dos meios tecnológicos, permitindo a difusão quase imediata de informações, notadamente por intermédio de novos equipamentos - computadores, câmeras, telefones celulares de última geração etc. -, e a inserção social cada vez maior dos meios de comunicação constituem um sério risco aos direitos fundamentais, especialmente à intimidade e à vida privada dos cidadãos.

NORBERTO BOBBIO dessa forma exteriorizou a sua preocupação com a referida situação:

Hoje, as ameaças à vida, à liberdade e à segurança podem vir do poder sempre maior que as conquistas da ciência e das aplicações dela derivadas dão a quem está em condições de usá-las. Entramos na era que é chamada de pós-moderna e é caracterizada pelo enorme progresso, vertiginoso e irreversível, da transformação tecnológica e, consequentemente, também tecnocrática do mundo. Desde o dia em que Bacon disse que a ciência é poder, o homem percorreu um longo caminho! O crescimento do saber só fez aumentar a possibilidade do homem de dominar a natureza e os outros homens. ${ }^{1}$

\footnotetext{
${ }^{1}$ BOBBIO, Norberto. Os direitos do homem hoje, in: A era dos direitos. 5. ed. Rio de Janeiro:
} Elsevier, , 2004, p. 229. 
E o confronto entre a liberdade de expressão e a intimidade pode emergir no curso da persecução penal, relacionando-se ainda com a publicidade desta.

Avaliar se existe ou não a possibilidade de ser a publicidade processual restringida, e em que medida, para a preservação da intimidade e da vida privada, atualmente ameaçadas pelo avanço dos meios tecnológicos e da grande inserção social dos meios de comunicação, que por vezes fazem do processo um "espetáculo" ${ }^{2}$, é o objetivo deste estudo.

Pelo que se vê, não bastasse a importância histórica, como conquista democrática do processo, do princípio da publicidade, faz-se atualmente necessária a sua releitura, à luz de uma nova realidade social, na qual os direitos fundamentais e o próprio Estado Democrático de Direito veemse ameaçados pelo avanço indevido da coletividade na esfera do indivíduo.

Com tal propósito, far-se-á no capítulo 1 do presente estudo uma análise inicial da inserção da publicidade no conjunto de garantias do devido processo legal, realizando-se ainda breves considerações sobre a evolução histórica da publicidade no processo, seguidas, no capítulo 2 , do estudo do tratamento que lhe é conferido nos diplomas internacionais voltados à proteção dos direitos fundamentais.

No capítulo 3 serão trazidas importantes noções conceituais sobre publicidade e sigilo.

${ }^{2}$ FERrajoli, Luigi. Direito e Razão - Teoria do Garantismo Penal. 2. ed. São Paulo: RT, 2006, p. 569. 
Estudar-se-á, no capítulo 4, a publicidade no plano da Constituição Federal de 1988 e, nos capítulos 5 e 6, respectivamente, no âmbito das investigações criminais e do processo.

O capítulo 7 conterá a abordagem da publicidade como "princípio" na teoria das normas, analisando-se também o princípio da proporcionalidade como método para a solução de conflitos decorrentes da colisão do princípio da publicidade com outros direitos fundamentais.

O capítulo 8 será dedicado ao estudo da possibilidade de limitação da publicidade para a defesa da intimidade, às vezes confrontada com a liberdade de expressão, no âmbito da investigação e do processo criminal.

As conclusões deste estudo, que não tem a pretensão de esgotar o tema, constarão, por fim, do capítulo 9. 


\section{1- A PUBLICIDADE NO QUADRO DAS GARANTIAS DO DEVIDO PROCESSO LEGAL - BREVE ANÁLISE HISTÓRICA DA PUBLICIDADE NO PROCESSO PENAL:}

\subsection{A função do processo penal}

O processo penal é atualmente concebido como um instrumento de pacificação social ${ }^{3}$, por intermédio do qual, ante a ocorrência de um ilícito penal de que decorre o surgimento de conflito entre a necessidade de aplicação do direito penal ao caso concreto e o jus libertatis do acusado, o Estado exerce o seu poder jurisdicional, sempre com a observância das garantias constitucionais do devido processo legal que legitimam o exercício de tal poder, dirimindo o conflito, com vistas a: “devolver à sociedade a paz desejada"4.

Dois são, pois, os direitos fundamentais que mais interessam ao processo penal, quais sejam, o direito à liberdade e o direito à segurança (artigo $5^{\circ}$, caput, da Constituição Federal). Deve, portanto, o processo, de uma parte, ser dotado de mecanismos que viabilizem a atuação das normas penais de forma efetiva e, de outra, propiciar ao acusado o amplo exercício do direito de

\footnotetext{
${ }^{3}$ ARAÚJo CINTRA, Antonio Carlos de; GRINOVER, Ada Pellegrini; e DINAMARCO, Cândido Rangel. Teoria Geral do Processo. 12. ed. São Paulo: Malheiros, p. 38-45. Assim discorrem os autores sobre o tema: "Seja ao legislar ou ao realizar atos de jurisdição, o Estado exerce o seu poder (poder estatal). E, assim como a jurisdição desempenha uma função instrumental perante a ordem jurídica substancial (para que esta se imponha em casos concretos), - assim também toda a atividade jurídica exercida pelo Estado (legislação e jurisdição, consideradas globalmente) visa a um objetivo maior, que é a pacificação social. É antes de tudo para evitar ou eliminar conflitos entre pessoas, fazendo justiça, que o Estado legisla, julga e executa (o escopo social magno do processo e do direito como um todo). O processo é, nesse quadro, um instrumento a serviço da paz social." (p. 41).

${ }^{4}$ Ibidem, p. 41.
} 
defesa de sua liberdade, traduzindo assim a idéia de processo justo, no qual existe equilíbrio entre eficiência e garantismo ${ }^{5}$.

A existência, no processo, de instrumentos que assegurem a atuação do direito penal e o amplo exercício do direito de defesa é, na perspectiva dos valores adotados em nosso ordenamento, o único meio apto a conduzi-lo ao seu escopo de pacificação social.

\subsection{A busca da verdade e as suas limitações}

A busca da verdade no processo penal configura, nesse contexto, relevante valor a ser perseguido, pois, somente a correta verificação dos fatos ou, mais precisamente, das assertivas feitas pelas partes sobre os fatos, que representam o objeto das provas e da decisão ${ }^{6}$, pode propiciar uma sentença justa ${ }^{7}$.

A disposição para o correto acertamento dos fatos encontra, todavia, algumas limitações.

5 Sobre o tema do equilíbrio entre a eficiência e o garantismo no processo: SACARANCE FERNANDES, Antonio. Reflexões sobre as noções de eficiência e garantismo no processo penal. In Sigilo no Processo Penal - Eficiência e Garantismo. Vários autores, sob a coordenação de Antonio Scarance Fernandes, José Raul Gavião de Almeida e Maurício Zanoide de Moraes. São Paulo: RT, 2008, p. 09-28.

${ }^{6}$ Giulio Ubertis defende a ideia de que as assertivas feitas pelas partes sobre os fatos e não os fatos propriamente ditos é que constituem o objeto das provas. UBERTIS, La ricerca della verità giudiziale, in La conoscenza del fatto nel processo penale, a cura di Giulio Ubertis. Milano: Giuffrè, 1992, p. 09-16.

${ }^{7}$ GOMes Filho, Antonio Magalhães. Direito à Prova no Processo Penal. São Paulo: RT, 1997 , p. 54 . 
Destaque-se inicialmente que a impossibilidade de manter o juiz contato direto com os fatos caracteriza, por si, considerável limitação à busca da verdade no processo, a qual se cingirá a uma reconstrução histórica dos fatos o quanto possível próxima da realidade dos acontecimentos ${ }^{8}$.

Outra limitação à busca da verdade diz respeito ao objeto da decisão a ser proferida, que deve restringir-se às assertivas feitas pelas partes sobre os fatos, sob pena de comprometimento do pleno exercício do direito de defesa ${ }^{9}$.

Relaciona-se com a referida limitação, especificamente no âmbito do processo penal, o princípio do estado de inocência ${ }^{10}$, que, entre outras coisas, interfere diretamente na questão atinente ao ônus da prova, atribuindo-o de forma mais contundente ao órgão acusador ${ }^{11}$.

Existe ainda a limitação quanto ao aspecto temporal, visto que a sucessão de atos praticados no processo conduzirá, dentro de prazos estabelecidos, à necessidade de ser proferida uma decisão, em princípio

${ }^{8}$ GOMES FILHO, Antonio Magalhães. Direito..., op. cit. p. 44.

9 Figueiredo DiAs, Jorge de. Direito Processual Penal. Coimbra: Coimbra Ed., 1974, reimpressa em 2004, p. 144-45.

10 Artigo 5 , inciso LVII, da Constituição Federal: “ninguém será considerado culpado até o trânsito em julgado da sentença penal condenatória.”

${ }^{11}$ Sobre a relação existente entre o ônus da prova e o princípio do estado de inocência no processo penal, de que decorre maior abrangência daquele ao órgão acusatório: BADARÓ, Gustavo Henrique Righi Ivahy. Ônus da Prova no Processo Penal. São Paulo: RT, 2003. 
imutável, havendo ou não correspondência entre a verdade sobre as assertivas feitas pelas partes e a sentença ${ }^{12}$.

Merecem também destaque as limitações de ordem constitucional e legal, que prestigiam, em detrimento da busca da verdade, outros valores. Enquadra-se nessa categoria a proibição às provas ilícitas, a vedação à utilização de conhecimentos privados pelo juiz, a obrigatoriedade, no direito processual penal brasileiro, da realização do exame de corpo de delito nas hipóteses de infrações penais que deixam vestígios ${ }^{13}$ etc. ${ }^{14}$.

Há, por derradeiro, as limitações concernentes à existência no processo, especialmente nos regimes democráticos, de outros valores ainda, que não o da busca da verdade a qualquer custo, a serem preservados, os quais se consubstanciam nas garantias do devido processo legal, que legitimam o conhecimento obtido no curso da relação jurídica processual.

Ora, apenas um processo imbuído de tais garantias confere legitimidade para que, num Estado Democrático de Direito, seja suprimido um dos direitos fundamentais do indivíduo, é dizer, a sua liberdade ${ }^{15}$.

${ }^{12}$ GOMES FILHO, Antonio Magalhães. Direito..., op. cit. p. 45.

13 Artigo 158 do Código de Processo Penal Brasileiro: "Quando a infração deixar vestígios será indispensável o exame de corpo de delito, direto ou indireto, não podendo supri-lo a confissão do acusado.

${ }^{14}$ GOMES FILHO, Antonio Magalhães. Direito..., op. cit. p. 45.

${ }^{15}$ Sobre a liberdade como direito fundamental do indivíduo: LAFER, Celso. O moderno e o antigo conceito de liberdade, in Ensaios sobre a liberdade. São Paulo: Perspectiva, 1980, p. 11-48. 
E isso porque o próprio processo também constitui uma garantia, à medida que condiciona o exercício do Poder do Estado, evitando o arbítrio, funcionando também como instrumento para a proteção efetiva dos direitos fundamentais, entre os quais se insere a liberdade ${ }^{16}$.

\subsection{As garantias processuais}

Posta a premissa de que exercem as garantias processuais importante papel na legitimação do exercício do poder jurisdicional, viabilizando ainda ao acusado a ampla defesa de seu direito à liberdade, passarse-á então a analisá-las.

\subsubsection{A imparcialidade do juiz}

As garantias do devido processo legal compreendem a necessidade de ser o processo julgado por um juiz imparcial, o que constitui um dos valores fundamentais da administração da justiça. Com efeito, a ausência de comprometimento do juiz na demonstração da tese acusatória ou da defensiva é condição sine qua non para a realização de julgamentos justos, daí porque existe grande debate na doutrina sobre os limites dos poderes instrutórios do magistrado no processo penal.

O debate em questão acirrou-se com o advento da nova redação do artigo 156 do Código de Processo Penal, o qual conferiu ao juiz a

\footnotetext{
${ }^{16}$ Sobre o processo como garantia politica geral, visando a impedir o arbítrio do exercício do poder, e como garantia especial de proteção aos direitos individuais: GOMES FILHO, Antonio Magalhães. A motivação das decisões penais. São Paulo: RT, 2001, p. 26-32.
} 
possibilidade de, entre outras coisas, ordenar, mesmo antes de iniciada a ação penal, a produção antecipada de provas consideradas urgentes e relevantes. A referida possibilidade reacendeu polêmica sobre os limites da atividade instrutória do juiz, a fim de que seja preservada a garantia da imparcialidade ${ }^{17}$ 18.

\subsubsection{O contraditório e a ampla defesa}

Abrangem, também, a necessidade de conferir-se às partes ciência dos atos processuais, a possibilidade de produzirem as suas provas, de apresentarem suas razões, em suma, de influírem efetivamente na decisão, ou seja, o direito ao contraditório ${ }^{19}$, a partir do qual o réu poderá exercer a ampla defesa.

O contraditório atribui especial legitimidade à sentença penal, pois viabiliza que a liberdade do indivíduo, valor fundamental, apenas

${ }^{17}$ GOMES FILHO, Antonio Magalhães, PRADO, Geraldo, GALlUZI DOS SANTOS, Leandro, BotTini, Pierpaolo Cruz, in As Reformas no Processo Penal: As novas Leis de 2008 e os Projetos de Reforma. Coordenado por Maria Thereza Rocha de Assis Moura. São Paulo, RT, p. 255-61, comentário feito por Antonio Magalhães sobre a nova redação do artigo 156 do CPPB realçando a importância do princípio da imparcialidade e acerca da discussão desencadeada pela nova redação do referido dispositivo legal.

${ }^{18}$ A nova redação do artigo 156 do CPPB - Art. 156. A prova da alegação incumbirá a quem a fizer, sendo, porém, facultado ao juiz de ofício: I - ordenar, mesmo antes de iniciada a ação penal, a produção antecipada de provas consideradas urgentes e relevantes, observando a necessidade, adequação e proporcionalidade da medida; II - determinar, no curso da instrução, ou antes de proferir sentença, a realização de diligências para dirimir dúvida sobre ponto relevante".

${ }^{19}$ ARAújo Cintra, Antonio Carlos de; GRINOVER, Ada Pellegrini; e DiNAMARCO, Cândido Rangel, op. cit., p. 55-57. 
possa sofrer algum tipo de restrição por intermédio de processo em que as partes participaram da produção do conhecimento submetido ao crivo judicial ${ }^{20}$.

Mas não é só.

Para além de constituir elemento que confere legitimidade política à decisão, a observância da garantia do contraditório, também possui componente epistemológico, à medida que a efetiva participação e controle das partes nos momentos de admissão, formação e valoração da prova propiciam decisões mais corretas sobre os fatos apurados no processo.

MICHELE TARUFFO sustenta que a atuação efetiva das partes nos momentos de admissão do material probatório no processo, de formação ou de efetiva produção da prova, e de previamente influir sobre a valoração da prova, tecendo considerações sobre os elementos de convicção levados ao processo, interfere na qualidade da prova e, conseqüentemente, da decisão ${ }^{21}$.

\subsubsection{A legalidade}

Ademais, é imprescindível que o devido processo legal seja informado pela legalidade. $\mathrm{O}$ respeito aos modelos legais previamente estabelecidos propiciam aplicabilidade, eficácia e efetividade às demais garantias.

\footnotetext{
${ }^{20}$ GOMES FILHO, Antonio Magalhães. Direito..., cit. p. 55.

${ }^{21}$ TARUFFO, Michele. La prova dei fatti giuridici. Milano: Giuffrè, 1992, p. 400-409.
} 


\subsubsection{A motivação das decisões judiciais}

A insuficiência dos modelos legais, seja no que se refere às regras que sistematizam as garantias processuais, seja no que diz respeito às normas de comportamento, conduzindo à inexorável necessidade de sua interpretação pelo Poder Judiciário, revela a importância fundamental de outra garantia, qual seja, a de motivação das decisões judiciais, atualmente expressa na Constituição Federal de 1988, em seu artigo 93, inciso IX, nos seus aspectos de garantia política, como justificação do exercício do poder que se mostra indeclinável num regime democrático, e endoprocessual de viabilizar o controle pelas partes das decisões proferidas, quanto ao mérito da ação penal, ou a outras questões levantadas no processo, inclusive relacionadas à observância das demais garantias, assim também se prestando a conferir-lhes efetividade ${ }^{22}$.

\subsection{5. a publicidade e a sua relação com as demais} garantias processuais

Por fim ${ }^{23}$, e também tendo como objetivo a preocupação de conferir aplicabilidade, eficácia e efetividade às demais garantias do devido

22 Sobre a importância da motivação das decisões judiciais como garantia processual: GOMES FILHO, Antonio Magalhães. A Motivação..., cit. p. 75-105.

${ }^{23}$ GOMES FILHO, Antonio Magalhães. A Motivação..., cit. p. 44-48. O autor discorre sobre a existência de polêmica doutrinária sobre a inserção do duplo grau de jurisdição entre as garantias processuais, posicionando-se no sentido de que o "duplo grau deve ser incluído entre as garantias do justo processo, seja como instrumento que propicia um grau mais elevado de correção dos pronunciamentos jurisdicionais, seja, especialmente no processo penal, como meio de proteção do indivíduo submetido à persecução; trata-se, acima de tudo de um desdobramento do direito à ampla defesa." 
processo legal ${ }^{24}$, a publicidade constitui um dos princípios fundamentais do processo penal no Estado Democrático de Direito, visto que assegura a transparência das investigações, instruções e julgamentos, de modo a evitar a violação das outras garantias processuais, bem como posturas e decisões arbitrárias, seja na fase do inquérito policial, seja no curso da relação jurídica processual.

É o princípio da publicidade que viabiliza a fiscalização pela comunidade e pelos atores processuais da legalidade dos procedimentos adotados no curso da apuração de uma infração penal e de sua autoria, conferindo ao investigado-acusado segurança acerca da observância das demais garantias processuais, sempre com vistas à realização de justiça nos julgamentos e, em última análise, à pacificação social, verdadeiro escopo do processo ${ }^{25}$.

ADA PELLEGRINI GRINOVER realça a importância de tal aspecto da publicidade, asseverando que:

O princípio da publicidade do processo constitui uma preciosa garantia do indivíduo no tocante ao exercício da jurisdição. A presença do público nas audiências e a possibilidade do exame dos autos por qualquer pessoa representam o mais seguro instrumento de fiscalização popular sobre a obra dos magistrados, do Ministério

\footnotetext{
${ }^{24}$ Antonio Magalhães destaca o aspecto de interpenetração das várias garantias, "não sendo possivel isolar completamente os seus vários aspectos" (GOMES FILHO, Antonio Magalhães. A Motivação..., cit. p. 49).

${ }^{25}$ ARAújo CINTRA, Antonio Carlos de, GrinOVER, Ada Pellegrini, e DinAMARCO, Cândido Rangel. Op. cit., p. 41.
} 
Público e dos defensores. Em última análise, o povo é o juiz dos juízes. E a responsabilidade das decisões judiciais toma outra dimensão, quando tais decisões hão de ser tomadas em audiência pública, na presença do povo ${ }^{26}$.

Prosseguindo, a referida autora ensina que: "o sistema de publicidade dos atos processuais representa uma das maiores garantias de independência, imparcialidade, autoridade e responsabilidade do juiz". ${ }^{27}$.

A publicidade assegura ainda, no plano processual, a atuação efetiva das outras garantias do devido processo legal, pois o acesso das partes às investigações e ao processo viabiliza um contraditório pleno e o exercício da ampla defesa, propiciando outrossim uma fiscalização interna sobre a imparcialidade do juiz e a motivação das decisões.

Neste ponto, cumpre destacar a relação que se estabelece entre a publicidade e as demais garantias processuais.

De um lado, como já se viu, ela viabiliza a fiscalização pelas partes e pelo público em geral acerca da imparcialidade do julgador.

${ }^{26}$ GRINOVER, Ada Pellegrini. Os Princípios Constitucionais e o Código de Processo Civil. São Paulo: Bushatsky, 1975, p. 130-131.

27 Ibidem, p. 132. 
De outro lado, ela viabiliza que o juiz tenha diante de si todo material relevante para a determinação, com imparcialidade, da culpa ou inocência de um acusado ${ }^{28}$.

A publicidade também faculta às partes acesso a toda informação que seja relevante para que, em contraditório, tenham condições de atuar em defesa de seus direitos.

Analisando-a sob outro prisma, deflui a publicidade do contraditório, que, entre outros, compreende o direito da parte de ter conhecimento sobre os atos processuais, a fim de que, com base em tal premissa, possa produzir provas de seu direito e influir na decisão.

A publicidade viabiliza outrossim o exercício do direito de defesa, que somente poderá ser desempenhado em sua plenitude na hipótese de ter o imputado plena ciência do teor da imputação, bem como dos elementos que a embasaram, mas, como na relação estabelecida com o contraditório, a publicidade também deflui do direito de defesa, decorrendo "logicamente da consagração do direito à defesa" 29 , pois, "para que haja uma defesa concreta, há que se garantir direito de acesso aos autos, a fim de que seja possibilitado o conhecimento efetivo sobre os fatos objeto da acusação" ${ }^{30}$.

${ }^{28}$ ABADE, Denise Neves. Direito de acesso aos autos no processo penal: breve análise crítica. In: RBCCRIM 57, ano 2005, p. 123.

${ }^{29}$ Idem.

${ }^{30}$ Ibidem, p. 126. 
Como se vê, ocupa a publicidade posição importante num complexo sistema de garantias processuais que se inter-relacionam, formando um "caleidoscópio de direitos" 31 .

Assim é que, de uma parte, a o princípio da publicidade deflui das demais garantias do processo e, de outra, constitui "garantia" de funcionamento daquelas.

LUIGI FERRAJOLI argumenta que a publicidade é a garantia:

que assegura o controle tanto externo como interno da atividade judiciária. Com base nela os procedimentos de formulação de hipóteses e de averiguação da responsabilidade penal devem desenvolver-se à luz do sol, sob o controle da opinião pública e sobretudo do imputado e seu defensor. Trata-se do requisito mais elementar e evidente do método acusatório. ${ }^{32}$

31 ABADE, Denise Neves. Direito de acesso aos autos... op. cit. p. 123. A expressão "caleidoscópio de direitos" foi, segundo a autora, cunhada por SAFFERLING: SAFFERLING, Christoph J.M. Towards an International Criminal Procedure. Oxford: Oxford University Press, 2003, p. 30.

${ }^{32}$ FERRAJOLI, Luigi. Direito e Razão..., op. cit, p. 567. 
O referido autor ainda estabelece "um nexo indissolúvel entre publicidade e democracia no processo",33.

\subsection{Breve análise sobre a evolução histórica da publicidade no processo penal}

A análise da evolução histórica da publicidade no processo é necessária porque revela, de um lado, a íntima relação que existe entre a margem de liberdade conferida ao indivíduo em face de um poder constituído em determinada localidade e momento histórico e o grau de transparência publicidade - por intermédio do qual o poder é exercido, de modo que é possível afirmar, grosso modo, que, quanto maior a transparência dos procedimentos relacionados ao exercício do poder num determinado regime político, mais democrático e compromissado com a tutela dos direitos fundamentais este será ${ }^{34}$.

De outro lado, tal estudo também propicia a compreensão dos motivos pelos quais, atualmente, se discutem eventuais hipóteses de limitações à publicidade, que possam conformar-se com a preservação de outros direitos fundamentais.

As considerações históricas restringir-se-ão, contudo, à análise histórica das raízes dos dois principais sistemas processuais atualmente existentes no mundo ocidental, os de civil law e os de common law.

\footnotetext{
${ }^{33}$ FERRAJOLI, Luigi. Direito e Razão..., op. cit., p. 569.

${ }^{34}$ Ibidem, p. 567-569.
} 


\subsubsection{O sistema de civil law}

\subsubsection{A antiguidade e o surgimento do processo}

ANA LÚCIA MENEZES VIEIRA ${ }^{35}$ aponta que a evolução do processo e da publicidade confunde-se com a evolução da própria sociedade, de maneira que surgiu o processo como forma mais civilizada de solução de litígios, alternativa à da vingança privada, já se colocando, desde então, a questão da publicidade. Hindus e hebraicos, pontua a autora, efetuavam os julgamentos em processos que tramitavam perante uma assembléia, em sessões orais e públicas, ao passo que no antigo Egito o processo desenvolvia-se de forma secreta e escrita, adotando-se mais tarde a publicidade de toda a instrução, à exceção do julgamento, que continuava a ser secreto ${ }^{36}$.

Na Grécia e na Roma republicana a publicidade do processo fazia-se presente ${ }^{37}$, desde então atuando como forma de garantia do indivíduo submetido a julgamento ${ }^{38}$. Ninguém, em tais sistemas, "poderia ser levado a julgamento sem que uma acusação pública e formal fosse efetivada"39.

\footnotetext{
${ }^{35}$ MeneZes Vieira, Ana Lúcia. Processo Penal e Mídia. São Paulo, RT, 2003, p. 74-75.

${ }^{36}$ Idem.

${ }^{37}$ FERRAJOLI, Luigi. Direito..., op. cit., 567-569.

${ }^{38}$ MENEZES VIEIRA, Ana Lúcia. Processo..., op. cit. p. 75-76.

39 BOSCHI, Marcus Vinicius. Publicidade e segredo dos atos processuais: (des)respeito às garantias fundamentais do acusado, in Revista Ibero-americana de Ciências Penais n. 3, Porto Alegre: 2001, p. 59.
} 
GABRIEL INACIO ANITUA explica que, na Grécia, especificamente na época clássica de Atenas, o processo era algo que afetava a todos os cidadãos e o tribunal era chamado de "Helión", pois as suas sessões ocorriam em praça pública, sob a luz do $\operatorname{sol}^{40}$.

Em Roma, segundo MARCUS VINICIUS BOSCHI, o processo iniciava-se com a accusatio (ação privada), podendo o acusado acompanhar todo o trâmite processual, com ampla ciência de tudo, a fim de respeitar-se o contraditório e, sobretudo, a publicidade do feito ${ }^{41}$.

A situação era, contudo, diferente na Roma imperial, com o estabelecimento do processo inquisitorial ${ }^{42}$. FERRAJOLI expõe que nesse período: "a sala das audiências (secretarium) começou a ser fechada por uma

40 ANITUA, Gabriel Ignacio. El principio de publicidad procesal penal: um análisis com base em La historia y el derecho comparado, in Las garantias penales y procesales, Enfoque histórico-comparado, Edmundo S. Hendler (comp.), Editores Del Puerto, Buenos Aires, 2001 , p. 68.

${ }^{41}$ BOSCHI, Marcus Vinicius. Publicidade e segredo... op. cit., p. 59-60.

42 JOSÉ FREDERICO MARQUES ensina que a "doutrina processual costuma classificar as várias formas históricas do processo penal em três grupos distintos: sistema acusatório, inquisitório e misto. O sistema acusatório, dominado, de modo geral pelo princípio homônimo (retro, n. ${ }^{\circ} 34$ ), apresenta, sob o ângulo histórico, os seguintes caracteres basilares: a) separação entre acusação, defesa e julgamento, uma vez que cada função é exercida por pessoas e órgãos entre si diversos; b) liberdade de defesa e igualdade de posição entre a acusação e o réu; c) procedimento público e dominado pela oralidade; d) julgamento popular, ou por órgãos judiciários imparciais; e) livre apresentação das provas pelas partes; f) ativação da causa pelas partes; g) o contraditório. No sistema inquisitivo, ao revés, há concentração das funções processuais (acusar, defender e julgar) no órgão judiciário, que é sempre um funcionário do rei ou autoridade subordinada ao poder governamental, cumprindo registrar, ao demais, que em tal sistema não há ampla defesa, e domina o princípio do segredo e do procedimento escrito, com ampla investigação judicial dos fatos, o emprego da tortura e averiguação não contraditória da imputação. O sistema processual misto surgiu após a revolução francesa: dividido o processo em fase instrutória e fase de julgamento, predomina naquela o sistema inquisitivo (sem as desumanidades, é evidente, das formas históricas deste), e no período do julgamento, o sistema acusatório." (MARQUES, José Frederico. Elementos de Direito Processual Penal. 2. ed. Campinas-SP: Millennium, 2000, p. 91-92). 
cortina (velum), que era levantada (levato velo) sempre que se desejava dar publicidade ao processo" ${ }^{\prime 43}$.

\subsubsection{O processo medieval}

A publicidade foi praticamente abolida na idade média, nas fases inquisitória e acusatória, em que imperava o segredo, à exceção do que ocorria na Inglaterra ${ }^{44}$.

Superada a fase dos duelos, juramentos, ordálias etc., que, "herdados dos costumes judiciários germânicos, submetiam os contendores a uma espécie de jogo, através do qual se manifestava a interferência divina na solução do conflito" ${ }^{45}$, surgiu a necessidade de racionalizar-se o método de apuração das responsabilidades pela prática de ilícitos, a fim de que as primeiras monarquias ocidentais lograssem impor a sua autoridade aos senhores feudais, consolidando o absolutismo.

Nesse modelo, o inquérito serviu como instrumento a viabilizar fossem atingidas as finalidades monárquicas, pese embora também tenha sido largamente utilizado pelas autoridades religiosas ${ }^{46}$.

Observa ANTONIO MAGALHÃES que:

\footnotetext{
${ }^{43}$ FERRAJOLI, Luigi. Direito..., cit. 567-569.

${ }^{44}$ Idem.
} 
Corolários dessas exigências eram o segredo, face ao perigo de propagação das condutas heréticas ou contestadoras do poder real, bem como o caráter praticamente ilimitado da pesquisa da verdade, que consistia em verdadeira obsessão do inquisidor ${ }^{47}$.

Todos os esforços eram despendidos na busca da confissão, admitindo-se até mesmo a tortura para a sua obtenção ${ }^{48}$.

FLÁVIA RAHAL pontua que, contrastando com um processo penal absolutamente sigiloso, as execuções eram públicas, constituindo espetáculos apreciados pela multidão ${ }^{49}$.

GABRIEL INACIO ANITUA assevera:

En la ceremonia del castigo se caía ele velo Del secreto Del proceso y el público se enteraba de las circunstancias que rodearon al crimen que atacaba a la voluntad soberano: el castigo público era la venganza, la manifestaciónd violência que recordaba al pueblo el poder

${ }^{45}$ GOMES FILHO, Antonio Magalhães. Direito..., op. cit., p. 20.

${ }^{46}$ Ibidem, p. 21.

${ }^{47}$ GOMES FILHO, Antonio Magalhães. Direito..., op. cit., p. 21.

${ }^{48}$ Idem.

49 RAHAL, Flávia. Publicidade no processo penal: a mídia e o processo, in RBCCRIM 47, ano 2004, São Paulo, p. 271. 
irrestricto de la ley y Del soberano, era um asunto político que sustentaba a aquel sistem $^{50}$.

O modelo inquisitivo era ainda complementado pela denominada teoria das provas legais, que, a despeito de sua aparência "garantista", quantificando e qualificando as provas que seriam necessárias à demonstração de determinado fato, dificultava de tal maneira a prova da infração que apenas realçou a ênfase dada pelos inquisidores à obtenção da confissão ${ }^{51}$.

A nota característica do modelo persecutório adotado no mencionado período era, pois, da ausência de publicidade, como reflexo de um regime político que se vinha impondo por intermédio da autoridade ${ }^{52}$.

\subsubsection{O iluminismo e a sua influência sobre o processo}

A noção de que a publicidade, em todas as fases do processo, constitui um importante óbice ao arbítrio foi trazida, ao final da idade média, pelo pensamento iluminista, como reação ao absolutismo, sufragada, entre

\footnotetext{
${ }^{50}$ ANITUA, Gabriel Ignacio. El principio de publicidad..., op. cit., p. 71.

${ }^{51}$ GOMES FILHO, Antonio Magalhães. Direito..., op. cit., p. 23-25.

52 Sintetizando as características dos processos que se desenvolveram durante a Santa Inquisição, instaurada em 1231 pelo papa Gregório IX, e dos processos medievais, MARCUS VINICIUS BOSCHI assevera que: "o processo que se desenvolvia contra os ditos 'propagadores da heresia' era absolutamente secreto, com provas tarifadas (valor legalmente atribuído), em que as prisões cautelares eram a regra, e não a exceção, admitida a tortura, com a nítida confusão entre acusador e julgador e que a presença de um defensor não era admitida, já que esta se mostrava como causa de um atraso ao célere desenvolvimento do processo. Estava, oficialmente, instaurado o sistema inquisitivo.” BOSCHI, Marcus Vinicius. Publicidade e segredo... op. cit., p. 60.
} 
outros, por BECCARIA, VOLTAIRE, FILANGIERI, ROMAGNOSI, PAGANO e BENTHAM ${ }^{53}$.

MARCUS VINICIUS BOSCHI aduz que:

\begin{abstract}
com o advento da chamada 'Época das Luzes' e o desenvolvimento de um racionalismo individualista, este panorama começou a sofrer lenta e gradual modificação em decorrência dos incisivos e frontais ataques lançados sobre as concepções medievais - inquisitórias. O desenvolver da racionalidade do século XVIII não mais autorizava a compreensão acerca de um processo religioso e judicial que fosse estritamente secreto, sem a presença de um advogado na defesa do acusado e que autorizasse o uso da tortura como meio de obtenção da verdade e salvamento da alma. Um Direito Criminal mais humano, justo e razoável passa a ser a aspiração dos letrados de então ${ }^{54}$.
\end{abstract}

Havia muitas críticas ao modelo inquisitório, propugnandose, com inspiração no modelo inglês do júri, por sua reforma, adotando-se, entre outras providências, a publicidade do processo, a sua oralidade e a

\footnotetext{
${ }^{53}$ FERRAJOLI, Luigi. Direito..., op. cit., , p. 567-69.

${ }^{54}$ BOSCHI, Marcus Vinicius. Publicidade e segredo... op. cit., p. 60-61.
} 
participação da defesa, refutando-se ainda a teoria da prova legal, substituída pela livre apreciação das provas ${ }^{55}$.

Sobrevieram, por ocasião da revolução francesa, reformas no processo penal, com destaque para a inserção da publicidade no ordenamento jurídico francês, por intermédio dos decretos de 8-9 de outubro de 1789 e de 16-29 de setembro de $1791^{56}$.

De acordo com FLÁVIA RAHAL, a publicidade nasceu com a revolução francesa:

para proteger o indivíduo e garantir direitos seus, humanizando o processo. Aparece ela alinhada à natureza política do processo, possibilitando a participação dos indivíduos nos atos da Justiça e com isso o exercício de seus direitos ${ }^{57}$.

Segundo ANTONIO MAGALHÃES, a fase inicial de investigação continuava a ser secreta, mas já havia alguma transparência, pois dela também participavam alguns cidadãos indicados pelas municipalidades.

${ }^{55}$ GOMES FILHO, Antonio Magalhães. Direito..., op. cit., p. 25-27.

${ }^{56}$ FERRAJOLI, Luigi. Direito..., op. cit. p. 569.

${ }^{57}$ RAHAL, Flávia. Publicidade..., op. cit., p. 271. 
Existia ainda uma segunda fase, perante um juiz, em que o procedimento transcorria com publicidade, sob o crivo do contraditório ${ }^{58}$.

\subsubsection{O sistema misto}

Consolidada a revolução, houve certo "abrandamento" dos ideais iluministas, de modo que a burguesia passou a fazer prevalecer o seu acentuado interesse na repressão criminal, ocorrendo sensíveis retrocessos no modelo processual, que voltou a contar com uma fase inquisitória precipuamente secreta, na qual eram colhidas provas que nem sequer eram repetidas em juízo.

O referido modelo veio a sofrer nova modificação, dando lugar a um sistema misto, com aspectos inquisitórios numa primeira fase e acusatórios numa segunda. O modelo em questão foi trazido, no período napoleônico, pelo Code d'instruction criminelle francês, de 1808, que previa segredo na primeira fase e publicidade na segunda ${ }^{59}{ }^{60}$, influenciando os demais ordenamentos da Europa continental e até mesmo alguns ordenamentos processuais penais atualmente em vigor.

\subsubsection{A Escola Penal Clássica e a Escola Positiva}

\footnotetext{
${ }^{58}$ GOMES FILHO, Antonio Magalhães. Direito..., op. cit., p. 28.

${ }^{59}$ FERRAJOLI, Luigi. Direito..., op. cit., p. 569;

${ }^{60}$ GOMES FILHO, Antonio Magalhães. Direito..., op. cit., p. 30-31.
} 
Seguiu-se, no século XIX, a escola liberal clássica, que voltou a conferir grande importância ao valor da publicidade no processo ${ }^{61}$.

As ideias sobre o valor da publicidade no processo foram posteriormente refutadas pela Escola Positiva, sob a justificativa da necessidade de busca eficiência no sistema penal, direcionado à satisfação do interesse público.

FERRAJOLI invoca o seguinte pensamento de um representante da Escola Positiva, R. GAROFALO, a fim de sintetizar o ideário da citada corrente sobre a publicidade no processo:

Só por meio do mais rigoroso segredo pode ser garantida a sinceridade da instrução. Mostrar ao imputado e a seu defensor aquela tênue linha que serve de guia no labirinto de um processo indiciário é o mesmo que deixar que a cortem $^{62}$.

${ }^{61}$ FERRAJOLI, Luigi. Direito..., op. cit., p. 569. O autor, na nota de n. 343, expõe que os autores da escola clássica defendiam a publicidade no processo: "F. Carrara, Programma. Parte generale, cit., I, p. 547, e II, par. 858, p. 316; L. Lucchini, ob. cit., p. 34. Anselm Feuerbach chegou a exigir não apenas a possibilidade, mas também a obrigação da presença do público (Über Öffentlichkeit und Mündlichkeit der Gerechtigkeitspflege, Giessen, 1821, p. 166 e ss., citado expressamente por V. Manzini, ob. Cit., vol. III, p. 33). Carmignani reservou ao invés a publicidade ao processo acusatório, repelindo-a no inquisitório (Teoria, cit., IV, p. 205-217; sobre isso vejam-se as críticas em F. Carrara, ob. Cit., II, p. 249). Sobre valores gerais da publicidade no direito público, recorde-se a máxima de Kant: 'Todas as ações relativas ao direito de outro homem cuja máxima não é suscetível de publicidade são injustas' (Zum ewigen Frieden (1795), trad. It. De G. Solari e G. Vidari, Per la pace perpetua, Appendice, II, Scritti politici, cit., p. 330)".

${ }^{62}$ Ibidem, p. 569. 
Segundo JOÃO MENDES DE ALMEIDA JÚNIOR, para a Escola Positiva:

a instrucção deve ser secreta e escripta, limitando-se a publicidade e a oralidade ao caso de contestação sobre o valor das provas do facto, sobre os antecedentes pessoaes e hereditários do indiciado e seus signaes anthropologicos ${ }^{63}$.

ANTONIO MAGALHÃES enfatiza que o pensamento positivista, preconizando um novo papel para o Estado na sociedade, que deveria contrapor-se ao exercido no modelo democrático-liberal, influenciou outras correntes posteriores, tendo "grande influência na codificação fascista de 1930 e, por reflexo, no nosso estatuto processual-penal de $1941^{\text {",64. }}$.

\subsubsection{O sistema de common law}

No sistema de common law, ou anglo-americano, que se desenvolveu inicialmente na Inglaterra e posteriormente foi adotado nos Estados Unidos, os juízos de Deus e ordálias foram substituídos pelos julgamentos populares, que paulatinamente evoluíram para um sistema precipuamente acusatório, em que o contraditório, a concentração de atos, a

63 Almeida Júnior, João Mendes de. O Processo Criminal Brasileiro, vol. I. 3. ed., Rio de Janeiro: Baptista de Souza, 1920, p. 253.

${ }^{64}$ GOMES FILHO, Antonio Magalhães. Direito..., op. cit., p. 33. 
oralidade e a publicidade são características marcantes, que, com algumas modificações ao longo do tempo ${ }^{65}$, subsistem até os dias atuais ${ }^{66}$.

\subsubsection{A evolução da publicidade no Brasil}

\subsubsection{O período colonial}

Como se pode supor, no período colonial, o processo penal subordinava-se às regras vigentes na metrópole Portugal, as Ordenações Afonsinas, Manuelinas e Filipinas ${ }^{67}$, as quais, em seu Livro V, disciplinavam um processo penal predominantemente inquisitivo, que admitia práticas cruéis e desumanas tais como a do tormento - tortura mediante açoites - para a obtenção de prova - confissão ${ }^{68}$. A ausência de publicidade, reservada apenas para alguns momentos, era uma das características do processo ${ }^{69}$.

JOÃO MENDES DE ALMEIDA JÚNIOR assevera que nos modelos processuais das Ordenações:

65 Sobre as características do sistema de common law e a evolução deste: DENTI, Vittorio. Evoluzione del diritto delle prove nei processi civili contemporanei, p. 31-69.

${ }^{66}$ ALEXANDRE DE MORAES assevera que a própria idéia de devido processo legal "remonta à Magna Charta Libertatum de 1215, de vital importância no direito anglo-saxão". MORAES, Alexandre de. Direito Constitucional. 20. ed. São Paulo: Atlas, p. 94.

${ }^{67}$ MARQUES, José Frederico. Elementos..., p. 95-100.

${ }^{68}$ Idem.

${ }^{69}$ Idem. 
A esquissa ou inquérito e o processo secreto desenvolveram, pois, o uso da tortura, em consequencia dos preconceitos que levaram a jurisprudencia a formular, como regra essencial, a necessidade da confissão do accusado. O juiz, habituado a fundar toda a instrução nas continuas perguntas ao réo, buscava todos os meios de extorquir esta confissão, ostentando uma habilidade sem escrupulo, quer para a suggestão, quer para as ciladas, quer para o cansaço do interrogado; e, si ainda assim nada conseguisse, recorria às ameaças e depois aos tormentos ${ }^{70}$.

Com a influência do iluminismo, cujo ideário propagava-se pela Europa, estabeleceram-se em Portugal, por intermédio da Constituição da monarquia portuguesa de 1821, algumas garantias de natureza penal e processual penal, que, no Brasil, também foram adotadas por aviso do então príncipe D. Pedro, em agosto de $1822^{71}$.

\subsubsection{O Império}

Após a proclamação da independência e a fundação do império, a Constituição Política do Império, de 1824, estabeleceu, em seu artigo 179, alguns princípios garantidores de direitos fundamentais do indivíduo, que repercutiram na seara do processo penal, e o Código de Processo

\footnotetext{
${ }^{70}$ ALMEIDA JÚNIOR, João Mendes de. O Processo Criminal Brasileiro..., op. cit., p. 148-149.

${ }^{71}$ MARQUES, José Frederico. Elementos..., p. 101.
} 
Criminal de 1832, de índole liberal, consolidou um sistema com mais garantias $^{72}$.

Na Constituição de 1824, segundo ANA LÚCIA MENEZES VIEIRA, a primeira referência à publicidade, embora não prevista no título da garantias, encontra-se prevista no artigo 159 (Título VI - "Do Poder Judicial”), que determinou a publicidade para a inquirição das testemunhas e os demais atos do processo praticados após a pronúncia ${ }^{73}$.

O Código, por sua vez, estabeleceu que as funções policiais fossem desenvolvidas por juízes de paz eleitos, bem como instituiu, com inspiração no sistema Inglês, dois Júris para os julgamentos dos crimes: um grande Júri, que decidia sobre a admissibilidade da acusação, e um pequeno Júri, que julgava a procedência desta. A publicidade imperava durante o sumário de culpa, o qual apenas se desenvolvia em segredo quando o réu não comparecesse a seus atos ${ }^{74}$.

Sob o influxo dos movimentos revolucionários que se sucederam entre 1830 e 1840 , houve reação conservadora, a qual culminou com uma lei promulgada em dezembro de 1841, que criou no município da Corte e

\footnotetext{
${ }^{72}$ José Frederico Marques tece o seguinte comentário sobre o Código de 1832: “Com a fundação do Império, abre-se, para o nosso processo penal, um período de reação às leis opressoras e monstruosas da monarquia portuguesa, e do qual o Código de Processo Criminal, de 1832, constitui o diploma legal culminante e mais expressivo, síntese que é dos anseios humanitários e liberais que palpitavam no seio do povo e nação. Este período, que só termina em 1841, é marcante e decisivo na formação e história de nossas instituições penais. Graças a ele, perdurou, nas leis nacionais, um acentuado espírito anti-inquisitorial que nos preservou o processo penal, de certos resíduos absolutistas, que ainda existem nos códigos europeus." MARQUES, José Frederico. Elementos..., op. cit. p. 102.

${ }^{73}$ MeneZeS VIEIRA, Ana Lúcia. Processo..., op. cit. 80.

${ }^{74}$ ALMEIDA JÚNIOR, João Mendes de. Processo Criminal Brasileiro..., op. cit., p. 190.
} 
nas demais províncias a figura do chefe de polícia e respectivos delegados e subdelegados, nomeados pelo Imperador ou pelos presidentes de província ${ }^{75}$, passando a vigorar "o policialismo mais arbitrário em matéria de processo criminal" "16, que perdurou até 1871, quando uma reforma processual, entre outras modificações, separou as funções de polícia e justiça, instituindo o inquérito policial ${ }^{77}$.

\subsubsection{A República}

Com o advento da República e a promulgação da Constituição de 1891, algumas inovações foram trazidas ao processo penal brasileiro, reafirmando-se garantias processuais já existentes, embora a publicidade não se fizesse mais presente no texto constitucional ${ }^{78}$, e atribuindose competências às unidades federativas para legislar sobre processo penal. No Estado de São Paulo e em outros Estados permaneceu em vigor o mesmo sistema processual do Império, com os seus princípios garantidores, mas alguns estados estabeleceram a formação da culpa secreta e chegaram a suprimir o inquérito policial ${ }^{79}$.

75 Ibidem, p. 208.

${ }^{76}$ MARQUES, José Frederico. Elementos..., cit.p. 105.

${ }^{77}$ Ibidem, p. 101.

${ }^{78}$ Malgrado não estivesse expressamente prevista no texto constitucional, era possível extrair-se a publicidade da cláusula da ampla defesa, prevista no artigo $72, \S 16$, da referida Constituição: "Aos accusados se assegurará na lei a mais plena defesa, com todos os recursos e meios essenciaes a ella, desde a nota de culpa, entregue em vinte e quatro horas ao preso e assignada pela autoridade competente, com os nomes do accusador e das testemunhas". Redação extraída de ALMEIDA JÚNIOR, João Mendes de. Processo Criminal Brasileiro..., op. cit., p. 233.

${ }^{79}$ MARQUES, José Frederico. Elementos..., cit.p. 108. 
As revoluções de 1930 e 1932 redundaram na aprovação da Constituição de 1934 , a qual restaurou o sistema de unidade processual ${ }^{80}$, mas não estabeleceu explicitamente a publicidade, que, contudo, poderia inferir-se das demais garantias processuais ${ }^{81}$, o mesmo ocorrendo com a Constituição de 1946, situação diversa da trazida pela Constituição de 1937, promulgada sob a ditadura Varguista, que, além de nada dispor sobre a publicidade, reduziu as garantias do processo penal ${ }^{82}$.

A Constituição de 1967, com a emenda de 1969, estabeleceu no seu artigo $153, \S 4^{\circ}$, a cláusula do devido processo legal, que abrange a publicidade, a qual também era possível inferir-se implícita no $\S 36$ do referido $\operatorname{artigo}^{83}$.

A publicidade, no ordenamento jurídico brasileiro, apenas foi alçada à categoria de garantia constitucional na Constituição de 1988, estabelecendo-a no Capítulo I (Dos direitos e deveres individuais e coletivos) do Título II (Dos direitos e garantias fundamentais), mais precisamente no

\footnotetext{
${ }^{80}$ Ibidem, p. 109.

${ }^{81}$ MENEZES VIEIRA, Ana Lúcia. Processo..., cit. p. 83.

${ }^{82}$ Idem.

83 Artigo 153, § 36: “a especificação dos direitos e garantias expressos nesta Constituição não exclui outros direitos e garantias decorrentes do regime e dos princípios que ela adota".
} 
artigo $5^{\circ}$, inciso $\mathrm{LX}^{84}$, e no Capítulo III (Do Poder Judiciário) do Título IV (Da organização dos Poderes), artigo 93, inciso $\mathrm{IX}^{85}$.

No plano infraconstitucional foi promulgado, em 1941, o Código de Processo Penal do Brasil, que, com algumas modificações, encontrase em vigor até os dias atuais.

O aludido diploma revigorou o sistema misto instituído no final do império, mantendo, numa primeira fase, o inquérito policial e, numa segunda, um processo preponderantemente acusatório.

A disciplina da publicidade no atual ordenamento jurídico brasileiro será adiante analisada em capítulo próprio.

${ }^{84}$ Artigo 5, LX: “a lei só poderá restringir a publicidade dos atos processuais quando a defesa da intimidade ou o interesse social o exigirem".

${ }^{85}$ O artigo 93, inciso IX, da Constituição Federal, possuía, por ocasião da promulgação da carta, a seguinte redação: “todos os julgamentos dos órgãos do Poder Judiciário serão públicos, e fundamentadas todas as decisões, sob pena de nulidade, podendo a lei, se o interesse público o exigir, limitar a presença, em determinados atos, às próprias partes e a seus advogados, ou somente a estes;". O texto foi posteriormente alterado pela Emenda 45/2004, passando a constar do dispositivo: "todos os julgamentos dos órgãos do Poder Judiciário serão públicos, e fundamentadas todas as decisões, sob pena de nulidade, podendo a lei limitar a presença, em determinados atos, às próprias partes e a seus advogados, ou somente a estes, em casos nos quais a preservação do direito à intimidade do interessado no sigilo não prejudique o interesse público à informação". 


\section{2- A PUBLICIDADE NO PLANO INTERNACIONAL:}

O sistema de garantias processuais, entre as quais a da publicidade do processo, cuja função foi delineada no capítulo introdutório, insere-se ainda num contexto mais amplo, ou seja, na esfera da universalização da proteção dos direitos humanos, com vistas à implementação e desenvolvimento das democracias, criando, na visão de NORBERTO BOBBIO, as condições para a possibilidade de paz no plano mundial ${ }^{86}$, a "paz perpétua", no sentido kantiano da expressão.

Nesse contexto, merece inicial destaque, em virtude de seu caráter universal, a francesa Declaração dos Direitos do Homem e do Cidadão, de 1789, que em seu artigo 7 estabeleceu:

Nul homme ne peute être accusé, arrête, ni détenu que dans les cas determines par la loi, et selon les formes qu'elle a prescrites. Ceux qui sollicitent, expedient, exécutent, ou fon exécuter des ordres arbitraires, doivent être punis; mais tout citoyen, appelé ou saisi em vertu de la loi, doit obéir à l'instant ${ }^{87}$.

${ }^{86}$ BOBBIO, Norberto. A Era dos Direitos. Rio de Janeiro: Elsevier, 2004, p. 21-22.

${ }^{87}$ TORnAGHI, Helio. Manual de Processo Penal, vol. 1, Prisão e liberdade. Rio de Janeiro, 1963, p. 82-83. Numa tradução livre: "Ninguém pode ser acusado, preso ou detido senão nos casos determinados pela lei e de acordo com as formas por esta prescritas. Os que solicitam, expedem, executam ou mandam executar ordens arbitrárias devem ser punidos; mas qualquer cidadão convocado ou detido em virtude da lei deve obedecer imediatamente, caso contrário torna-se culpado de resistência". 
Imbuída do ideário iluminista, a mencionada declaração compreende o embrião, no plano internacional, da concepção de um processo legal e garantista como condição para o exercício do poder punitivo estatal. Embora não explicitada no texto, infere-se, de sua interpretação sistemática, a necessidade de publicidade do processo.

A Declaração dos Direitos do Homem e do Cidadão influenciou os diplomas internacionais posteriores à Segunda Grande Guerra Mundial, que, propondo um caminho para a reconstrução dos direitos humanos, abalados com as rupturas totalitárias do século XX, buscam o desenvolvimento das democracias e o estabelecimento de condições para a existência de paz no plano mundial ${ }^{88}$.

O principal diploma internacional do pós-guerra consiste na Declaração Universal dos Direitos Humanos, de 1948, a qual expressamente estabeleceu a publicidade no processo em seu artigo $\mathrm{X}$ :

“Toda pessoa tem direito, em plena igualdade, a uma audiência justa e pública por parte de um tribunal independente e imparcial, para decidir de seus direitos e deveres ou do fundamento de qualquer acusação criminal contra ele" $" 89$.

\footnotetext{
${ }^{88}$ A respeito da reconstrução dos direitos humanos, LAFER, Celso. A reconstrução dos direitos humanos - Um diálogo com o pensamento de Hannah Arendt. 6. ed. São Paulo: Companhia das Letras, 2006.

${ }^{89}$ Disponível em:<www.onu-brasil.org.br $>$, consultado em 7 de janeiro de 2009.
} 
Ainda no plano internacional cabe mencionar o Pacto Internacional dos Direitos Civis e Políticos de 1966 (ratificado pelo Brasil em 1992), prescrevendo em seu artigo 14-1:

Todas as pessoas são iguais perante os Tribunais e as Cortes de Justiça. Toda pessoa terá o direito de ser ouvida publicamente e com as devidas garantias por um Tribunal competente, independente e imparcial, estabelecido por lei, na apuração de qualquer acusação de caráter penal formulada contra ela ou na determinação de seus direitos e obrigações de caráter civil. A imprensa e o público poderão ser excluídos de parte ou da totalidade de um julgamento, quer por motivo de moral pública, ordem pública ou de segurança nacional em uma sociedade democrática, quer quando o interesse da vida privada das partes o exija, quer na medida em que isto seja estritamente necessário na opinião da justiça, em circunstâncias específicas, nas quais a publicidade venha a prejudicar os interesses da justiça; entretanto, qualquer sentença proferida em matéria penal ou civil deverá tomarse pública, a menos que o interesse de menores exija procedimento oposto ou o processo diga respeito a controvérsias matrimoniais ou à tutela de menores ${ }^{90}$.

Desperta grande interesse, neste diploma, não apenas a expressa previsão da publicidade, mas a disciplina de hipóteses em que é possível a sua limitação, para a imprensa e o público, por razões de interesse

${ }^{90}$ Disponível em: < www.aids.gov.br/legislacao/vol1_2.htm>, consultado em 7 de janeiro de 2009. 
público, para preservar a intimidade das partes e a fim de não prejudicar os interesses da justiça.

Merece lembrança, agora no âmbito regional de proteção dos direitos humanos, a Convenção Européia dos Direitos do Homem - Roma, 1950 - , dispondo em seu artigo $6^{\circ}$ que:

1- Qualquer pessoa tem direito a que a sua causa seja examinada, eqüitativa e publicamente, num prazo razoável por um tribunal independente e imparcial, estabelecido pela lei, o qual decidirá, quer sobre a determinação dos seus direitos e obrigações de caráter civil, quer sobre o fundamento de qualquer acusação em matéria penal dirigida contra ela. O julgamento deve ser público, mas o acesso a sala de audiências pode ser proibido à imprensa ou ao público durante a totalidade ou parte do processo, quando a bem da moralidade, da ordem pública ou da segurança nacional numa sociedade democrática, quando os interesses de menores ou a proteção da vida privada das partes no processo o exigirem, ou, na medida julgada estritamente necessária pelo tribunal, quando, em circunstâncias especiais, a publicidade pudesse ser prejudicial para os interesses da justiça ${ }^{91}$.

${ }^{91}$ Disponível em: <www.cidadevirtual.pt.cpr/asilo1.cesdh.html $>$, consultado em 7 de janeiro de 2009. 
A convenção contempla, como se vê, a publicidade e as mesmas hipóteses de restrição constantes do Pacto Internacional dos Direitos Civis e Políticos.

A publicidade está também expressamente prevista na Carta dos Direitos Fundamentais da União Européia, proclamada em dezembro de 2000 e, numa segunda oportunidade, em dezembro de 2007, no seu artigo 47º, que não contempla, contudo, as limitações do Pacto e da Convenção Européia ${ }^{92}$.

Um último sistema regional a destacar-se no presente trabalho consiste na Convenção Americana sobre Direitos Humanos, de 1969, conhecida como Pacto de São José da Costa Rica, ratificada pelo Brasil em 1992.

O artigo $8^{\circ}$ da Convenção, que cuida das garantias judiciais, assim dispõe em seu n. 5: “O processo penal deve ser público, salvo no que for necessário para preservar os interesses da justiça" $"$.

Reafirmada, portanto, no âmbito da Convenção Americana, a publicidade do processo penal, embora com ressalva um pouco diversa das constantes dos outros diplomas internacionais, relativa à possibilidade de sua limitação para preservar os interesses da justiça.

\footnotetext{
${ }^{92}$ Disponível em: <www.europarl.europa.eu/charter/pdf/text_pt.pdf $>$, consultado em 7 de janeiro de 2009.

${ }^{93}$ Disponível em: <www2.idh.org.br/casdh.htm>, consultado em 7 de janeiro de 2009.
} 
A relevância do estudo dos diplomas internacionais referidos decorre da tendência apontada por ANTONIO SCARANCE de internacionalização do direito processual ${ }^{94}$, repercutindo, no ordenamento jurídico brasileiro, nos $\S \S 2^{\circ}$ e $3^{\circ}$ do artigo $5^{\circ}$ da Constituição Federal:

\begin{abstract}
$\S 2 .^{\circ}$ Os direitos e garantias expressos nesta Constituição não excluem outros decorrentes do regime e dos princípios por ela adotados, ou dos tratados internacionais em que a República Federativa do Brasil seja parte.
\end{abstract}

$\S 3^{\circ}$ Os tratados e convenções internacionais sobre direitos humanos que forem aprovados em cada Casa do Congresso Nacional, em dois turnos, por três quintos dos votos dos respectivos membros, serão equivalentes às emendas constitucionais ${ }^{95}$.

Antes do advento do $\S 3^{\circ}$ havia discussão doutrinária e jurisprudencial sobre o status com o qual os tratados internacionais ingressavam no ordenamento jurídico naciona $1^{96}$.

É bem verdade que a Emenda de n. 45/2004 tentou eliminar a mencionada discussão, não logrando, contudo, êxito, pois ainda existe

${ }^{94}$ SCARANCE FERnANDES, Antonio. Processo..., op. cit., p. 25.

${ }^{95} \mathrm{O} \S 3^{\circ}$ foi acrescentado pela Emenda Constitucional n. ${ }^{\circ} 45$, de 8 de dezembro de 2004.

${ }^{96}$ Antonio Scarance, citando Flavia Piovesan, destaca que havia forte tendência doutrinária a se atribuir às normas de direitos humanos o status de normas constitucionais, mas que o Supremo Tribunal Federal recusava-se a reconhecer-lhes dignidade constitucional. SCARANCE FERNANDES, Antonio. Processo..., cit. 26-27. 
entendimento doutrinário sustentando que os tratados internacionais sobre direitos humanos, mesmo que não aprovados pelo quorum especificado no $\S 3^{\circ}$ do artigo $5^{\circ}$, possuem o status de normas constitucionais, em virtude de sua constitucionalidade material, notadamente os tratados aprovados antes de aludida Emenda ${ }^{97}$.

De qualquer forma, seja qual for a natureza normativa dos tratados incorporados ao ordenamento jurídico brasileiro - normas constitucionais ou infraconstitucionais -, inquestionável é a sua repercussão jurídica no sistema pátrio de tutela dos direitos fundamentais, que, no mínimo, deverá ter a sua interpretação influenciada pelos diplomas internacionais, cabendo, por fim, reiterar que, à exceção dos tratados europeus, os demais diplomas mencionados neste capítulos já fazem parte do ordenamento nacional.

${ }^{97}$ LEMOS, Tayara Talita. A Emenda Constitucional 45/04 e as Alterações na Recepção dos Tratados Internacionais de Direitos Humanos. Centro de Direito Internacional. Revista Eletrônica de Direito Internacional, 2007. Disponível em: < $\underline{w w w . c e d i n . c o m . b r / r e v e l e t r o n i c a>, ~}$ acessado em 07 de janeiro de 2009.

André Pires de Andrae Kehdi esclarece que, em verdade, existem sobre o polêmico tema quatro correntes: "Os tratados teriam: 1. hierarquia supraconstitucional; 2. hierarquia constitucional; 3 . hierarquia intermediária: infraconstitucional, mas supralegal - esta defendida pelo Min. Gilmar Mendes no julgamento do RE 466.343, pelo pleno do STF, ainda em andamento, noticiado no Informativo 449; e 4. hierarquia equiparada à de lei ordinária. Tanto o STF (HC 72.131/RJ. Pleno, rel. Min. Celso de Mello, j. 23.11.1995, m.v., DJU 01.08.2003), quanto o STJ (HC 49.004/PR, 5 ${ }^{\mathrm{a}}$ T., rel. Min. Felix Fischer, j. 02.02.2006, v.u., DJU firmaram posicionamento em favor da quarta corrente. Não nos parece essa, entretanto, a melhor posição. Erigido a pilar fundamental do nosso Estado o cânone da dignidade da pessoa humana (art. $1^{\circ}$, III, CF), à disposição do $\S 2^{\circ}$, do art. $5^{\circ}$, há que se conferir a maior concretude possível. Qualquer tratado internacional que passe a integrar o nosso ordenamento jurídico, assim o faz com hierarquia constitucional (nesse sentido: PIOVESAN, Flávia. Direitos humanos...cit. p. 93-94). E nossa posição não se alterou com a entrada em vigor da EC 45. Na mesma linha: PIOVESAN, Flávia. Tratados internacionais de proteção dos direitos humanos e a constituição Federal de 1988 . Bol. IBCCrim, ano 13, n. 153, p. 8-9, São Paulo, ago. 2005; GRINOVER, Ada Pellegrini; SCARANCE FERNANDES, Antonio; GOMES FILHO, Antonio Magalhães. Nulidades no Processo penal. 9. ed. São Paulo: RT, 2006, p. 25." (ANDRADE KEHDI, André Pires. O sigilo da ação penal Aspectos gerais. In: Sigilo no Processo Penal - Eficiência e Garantismo. Vários autores, sob a coordenação de Antonio Scarance Fernandes, José Raul Gavião de Almeida e Maurício Zanoide de Moraes. São Paulo: RT, 2008, p. 68. 


\section{3- A PUBLICIDADE - NOÇÕES CONCEITUAIS:}

\section{1. nota introdutória}

Já foram feitas, no prsente trabalho, considerações acerca das raízes ideológicas da publicidade, que remetem aos ideários iluminista e liberal, bem como sobre a importância da publicidade na seara das garantias do processo (capítulo 1) e no âmbito do sistema internacional de proteção dos direitos humanos (capítulo 2).

Resta, neste passo, a análise de como se manifesta no processo a garantia da publicidade.

\subsection{Publicidade - noções gerais}

Sobre o significado de publicidade, aduz ANDRE PIRES DE ANDRADE KHEDI:

Diz-se que o termo é "formado de público, do latim publicus, de publicare (publicar, dar ao público, expor ao público)'. Assevera Plácido e Silva que "a publicidade, dentro de sua finalidade jurídica, pretende tornar a coisa 
ou o fato de conhecimento geral, isto é, para que todos possam saber ou conhecer o fato a que se refere" 98 .

A noção de publicidade traduz, em síntese, a idéia de conferir acesso ao público, de forma indiscriminada e irrestrita.

\begin{abstract}
ALBERTO MANUEL LOPEZ LOPEZ assevera que: "um procedimiento es publico cuando tienen libre acceso a su contenido de personas ajenas al órgano judicia." 99.
\end{abstract}

\title{
3.2.1. Publicidade externa e interna
}

A primeira observação sempre levada a efeito pela doutrina nacional e estrangeira, embora haja pequenas diferenças semânticas e de conteúdo $^{100}$, reside no aspecto de que a compreensão da manifestação da publicidade no processo deve partir da premissa conceitual sobre a existência de uma publicidade externa, que repercute fora do processo, e de uma

${ }^{98}$ ANDRADE KEHDI, André Pires. O sigilo... op. cit., , p. 58. As citações constantes do trecho foram extraídas de DE PLÁCIDO E SILVA. Vocabulário jurídico. 15. ed. Rio de Janeiro: Forense, 1999, p. 758.

99 LOPEZ LOPEZ, Alberto Manuel. Publicidad, Indefension y Tutela Judicial Efectiva, in: Actualidad Penal n. 27, Madrid: 1993, p. 375.

${ }^{100}$ SCARANCE FERNANDES, Antonio, Processo..., cit. p. 72. 
publicidade endoprocessual, que apenas atinge as partes, seus procuradores e o julgador $^{101}$.

A publicidade externa liga-se à idéia de transparência e legitimidade do exercício do poder, que deve ser fiscalizado ex parte populi, compreendendo, pois, a possibilidade de serem os atos processuais acessados pelo público em geral, que pode sofrer restrições decorrentes da necessidade de serem tutelados outros valores igualmente relevantes.

A publicidade interna, entretanto, refere-se ao direito que partes, procuradores e julgador possuem de terem conhecimento integral sobre o conteúdo do processo, abrangendo a prévia ciência dos atos a serem praticados, presença física nos atos de que participem e intimação dos atos realizados sem sua direta participação.

ALBERTO MANUEL LOPEZ LOPEZ salienta que se trata do "derecho fundamental de las partes a conocer inmediatamente la dirección y sentido de lãs actuaciones procesales, condición previa e ineludibile del ejercicio de su derecho a la defensa" ${ }^{, 102}$, em princípio irrestrito.

Além de também exercer a função de fiscalização das partes sobre o exercício do poder jurisdicional, a publicidade interna é extremamente

101 LOPEZ LOPEZ, Alberto Manuel. Publicidad..., op. cit., p. 375-386. Madrid, Actualidad Editorial, 1993; GOMES FILHO, Antonio Magalhães. A Motivação..., cit. p. 50; MENEZES VIEIRA, Ana Lúcia. Processo...cit. p. 97.

${ }^{102}$ LOPEZ LOPEZ, Alberto Manuel. Publicidad..., op. cit., p. 375-386. 
importante, pois viabiliza a atuação de outras garantias processuais, como as do contraditório e ampla defesa ${ }^{103}$.

\subsubsection{Publicidade imediata e mediata}

De se ressalvar inicialmente que a diferenciação entre publicidade imediata e mediata diz respeito apenas à publicidade externa, visto que, como se viu, os atores processuais devem ter acesso direto e imediato ao processo.

Por um lado, a publicidade imediata confere ao público o acesso direto e imediato aos atos do procedimento ou à sua publicação por intermédio da imprensa oficial ${ }^{104}$.

Por outro lado, a evolução dos meios tecnológicos - telefones portáteis, televisão, internet etc. - e a inserção cada vez maior dos meios de comunicação viabilizaram o surgimento de uma publicidade mediata, propiciando o contato do público com o processo por intermédio da mídia. A publicidade mediata compreende o acesso direto dos atores da mídia ao processo e a sua faculdade de divulgá-los.

A distinção mostra-se sobremaneira relevante, sobretudo para fins de delimitação do âmbito de abrangência de determinada restrição à publicidade, como se verá adiante.

\footnotetext{
${ }^{103}$ V. abordagem sobre a interpenetração das garantias do processo no capítulo I.

${ }^{104}$ MENEZES VIEIRA, Ana Lúcia. Processo...cit. p. 96.
} 


\subsubsection{Publicidade plena ou irrestrita e publicidade}

restrita

A publicidade interna e externa deve, em regra, ser irrestrita $^{105}$, até para que possa realizar os valores político e processual que constituem a razão de sua existência.

É certo, todavia, que existem valores outros, não menos importantes, contemplados num ordenamento jurídico, que podem por vezes contrapor-se à publicidade plena, justificando, sempre à luz de um raciocínio de proporcionalidade, o sacrifício parcial da publicidade, o que deve ser analisado no caso concreto.

Os citados valores que justificam, num processo específico, a "compressão" da garantia fundamental da publicidade consubstanciam-se na necessidade de proteção da intimidade do indivíduo contra a ingerência indevida do público sobre o privado; no interesse social na apuração de determinadas infrações penais que a publicidade irrestrita inviabilizaria; no interesse da própria justiça, para que não haja comprometimento do escopo processual produzir uma decisão justa.

105 Parte da doutrina sustenta que a publicidade interna nunca pode ser restringida, sob pena de comprometimento do exercício de outras garantias processuais. Nesse sentido: GOMES FILHO, Antonio Magalhães. A Motivação..., cit. p. 50. Em sentido contrário, admitindo a restrição da publicidade interna com base no princípio da proporcionalidade: ZANOIDE DE MORAES, Maurício. Publicidade e proporcionalidade na persecução penal brasileira. In: Sigilo no Processo Penal - Eficiência e Garantismo. Vários autores, sob a coordenação de Antonio Scarance Fernandes, José Raul Gavião de Almeida e Maurício Zanoide de Moraes. São Paulo: RT, 2008, p. 29-55. 
Diz-se, pois, que há publicidade restrita quando, prestigiando quaisquer dos valores supracitados, existe no processo decisão motivada restringindo parcialmente a publicidade e modulando o âmbito de abrangência da restrição.

As questões mais relevantes relacionadas ao âmbito de abrangência das restrições à publicidade, o presente estudo, sem a pretensão de esgotar o tema, pretende abordar.

\subsection{A publicidade, o sigilo e o segredo}

Partindo da premissa de que a noção de publicidade opõe-se, de forma geral, às ideias de sigilo e segredo, cabe ainda preliminarmente fazer uma distinção entre sigilo e segredo.

ANDRE PIRES DE ANDRADE KEHDI esclarece que os termos sigilo e segredo, pese embora por muitos utilizados como sinônimos, não se confundem:

De fato, o primeiro deriva do latim sigillum, "marca pequena, sinalzinho, selo". Impera nele "a idéia de algo que está sob o selo, ou sinete, o sigilo traduz, com maior rigor, o segredo que não pode nem deve ser violado".

Do latim secretum, por sua vez, segredo "(secreto, guardado em segredo) exprime o que se tem em um conhecimento particular, sob reserva, ou ocultamente. É o 
que não se deve, não se quer, ou não se pode revelar, para que não se torne público, ou conhecido".

A ideia do selo da cera que se costumava estampar nas cartas antigamente, parece-nos definitiva para esclarecer a diferença: basta imaginar que o segredo é o conteúdo da correspondência e o sigilo é a maneira como o emitente garante a sua inviolabilidade ${ }^{106}$.

Constitui, assim, o sigilo o mecanismo por intermédio do qual o segredo é protegido.

A distinção revela portanto que, no âmbito do processo, a ideia de sigilo melhor se contrapõe à de publicidade.

E a restrição à publicidade pode dar-se pela determinação do sigilo que protegerá o segredo dos dados constantes do processo, necessário para a tutela de outros valores fundamentais.

106 ANDRADE KEHDI, André Pires. O sigilo..., cit. p. 58. As citações constantes do trecho foram extraídas de BUARQUE DE HOLANDA, Aurélio. Novo dicionário da língua portuguesa 2. ed. Rio de Janeiro: Nova Fronteira, 1986, p. 1.562. 


\section{4- A PUBLICIDADE NO PLANO CONSTITUCIONAL:}

A promulgação da Constituição de 1988 atribuiu dignidade constitucional à publicidade do processo ${ }^{107}$, contemplando-a expressamente em dois dispositivos, inseridos, respectivamente, nos artigos $5^{\circ}$ e 93.

$\mathrm{O}$ artigo $5^{\circ}$, inserido no Capítulo I (Dos direitos e deveres individuais e coletivos) do Título II (Dos direitos e garantias fundamentais), assim dispõe em seu inciso LX: “a lei só poderá restringir a publicidade dos atos processuais quando a defesa da intimidade ou o interesse social o exigirem;".

Já o artigo 93, inserto no Capítulo III (Do Poder Judiciário) do Título IV (Da organização dos Poderes), possuía em seu inciso IX, por ocasião da promulgação da Constituição, a seguinte redação:

IX - todos os julgamentos dos órgãos do Poder Judiciário serão públicos, e fundamentadas todas as decisões, sob pena de nulidade, podendo a lei, se o interesse público o exigir, limitar a presença em determinados atos, às próprias partes e a seus advogados, ou somente a estes.

O inciso ora comentado sofreu, contudo, modificações trazidas pela Emenda Constitucional 45 de 2004, passando a contar com outro texto:

${ }^{107}$ V. apontamentos sobre a evolução histórica da publicidade no Brasil, capítulo I. 
IX - todos os julgamentos dos órgãos do Poder Judiciário serão públicos, e fundamentadas todas as decisões, sob pena de nulidade, podendo a lei limitar a presença, em determinados atos, às próprias partes e a seus advogados, ou somente a estes, em casos nos quais a preservação do direito à intimidade do interessado no sigilo não prejudique o interesse público à informação.

A modificação do texto constitucional parece sugerir, para parte da doutrina ${ }^{108}$, alguma preponderância do interesse público à informação sobre o direito à intimidade do interessado, todavia MAURÍCIO ZANOIDE DE MORAES alerta para o fato de que o dispositivo não justifica o incondicional sacrifício dos valores que tutelam a liberdade individual em prol da preservação de um genérico direito à informação da coletividade, devendo-se "fazer sua leitura em consonância com todos os demais princípios constitucionais"109, que impõem a relativização, mas nunca a total supressão, de um direito fundamental apenas nas hipóteses fáticas em que se mostre necessária à preservação de outro direito fundamental.

NAGIB SLAIBI FILHO, contudo, observa aspectos positivos na modificação operada por intermédio da Emenda 45/2004, pois do novo texto do inciso IX do artigo 93 passou a constar expressa referência sobre a possibilidade de restrição da publicidade para a preservação da intimidade ${ }^{110}$,

\footnotetext{
${ }^{108}$ ZANOIDE DE MORAES, Maurício. Publicidade e proporcionalidade..., op. cit. p. 52 ${ }^{109}$ Idem.

110 SLAIBI FILHO, Nagib. A publicidade no processo judicial (notas sobre a nova redação do art. 93, IX, da Constituição), in Revista de Direito do Tribunal de Justiça do Estado do Rio de Janeiro n. 63, abril/junho de 2005, p. 381-386. Anteriormente só havia, no dispositivo, previsão sobre a restrição para a preservação do interesse público.
} 
mas, seguindo a mesma linha de MAURÍCIO ZANOIDE DE MORAES, salienta que a relativização de um direito fundamental sempre demandará a aplicação da proporcionalidade.

Extrai-se, em suma, dos dispositivos constitucionais que disciplinam a publicidade do processo, que, no sistema constitucional pátrio, em consonância com os modelos estabelecidos nos diplomas internacionais sobre a matéria e com os ordenamentos jurídicos de índole democrática, a publicidade do processo é a regra, “com inevitáveis instantes de excepcionalidade constitucional de sigilo para alguns atos e em certas circunstâncias. Essa excepcionalidade é que deve, em cada caso concreto, passar pelo crivo da proporcionalidade, com o objetivo de atingir a legitimidade constitucional indispensável a todo ato estatal"111.

É ainda importante destacar que, para a corrente de pensamento que confere dignidade constitucional aos tratados sobre direitos humanos $^{112}$, os diplomas internacionais que vigoram no Brasil disciplinando a publicidade no processo também integram o sistema normativo constitucional brasileiro sobre o tema.

Emerge de tal posicionamento nova discussão, sobre a necessidade de lei para que se possa restringir a publicidade do processo, à medida em que o texto constitucional exige a regulamentação do tema por intermédio de lei e os diplomas internacionais sobre direitos humanos que

\footnotetext{
${ }^{111}$ ZANOIDE DE MORAES, Maurício. Publicidade e proporcionalidade..., op. cit. p. 42.

${ }^{112} \mathrm{~V}$. discussão sobre o polêmico tema no capítulo II.
} 
integram o ordenamento jurídico brasileiro não mencionam a exigência de lei para que se imponha a restrição ${ }^{113}$.

ANDRE PIRES DE ANDRADE KEHDI apresenta ao problema a melhor solução, defendendo a reserva de lei ordinária para a restrição da publicidade no processo, ao argumento de que o regime constitucional, insuscetível de modificação em prejuízo da tutela de garantia individual (artigo 60, $4^{\circ}$, inciso IV, da Constituição Federal), protege de forma mais ampla o direito fundamental em comento ${ }^{114}$.

Em ulteriores capítulos deste trabalho discorrer-se-á sobre as hipóteses de restrição a publicidade no processo penal.

${ }^{113}$ V. capítulo II.

${ }^{114}$ ANDRADE KEHDI, André Pires. O sigilo..., cit. p. 68. 


\title{
5- AS INVESTIGAÇÕES CRIMINAIS E A PUBLICIDADE:
}

Considerando as balizas constitucionais já analisadas, que relegam à lei ordinária a possibilidade de imposição de restrição da publicidade para a defesa da intimidade e por exigência do interesse social, a análise das normas infraconstitucionais que disciplinam o tema ganha especial relevância.

\subsection{A publicidade na fase de investigação}

JOSÉ FREDERICO MARQUES ensina que:

\begin{abstract}
investigação é atividade estatal da persecutio criminis destinada a preparar a ação penal. Daí apresentar caráter preparatório e informativo, visto que seu objetivo é o de levar aos órgãos da ação penal os elementos necessários para a dedução da pretensão punitiva em juízo ${ }^{115}$.
\end{abstract}

A propositura da ação penal exige a preexistência de indícios da ocorrência de uma infração penal e de que determinado indivíduo foi o seu autor, sob pena de rejeição, com fundamento no artigo 395, inciso III, do

${ }^{115}$ MARQUES, José Frederico. Elementos..., vol. 1., p. 152. 
Código de Processo Penal, com a nova redação trazida pela Lei n. 11.719/08 ${ }^{116}$, a fim de evitar acusações arbitrárias, desprovidas de algum lastro probatório.

A investigação é realizada num momento pré-processual, a ela não se aplicando, em princípio, as garantias do devido processo legal.

FREDERICO MARQUES também explica que, embora se trate de atividade eminentemente administrativa, a investigação pode ser feita por órgãos não administrativos ${ }^{117}$, e atualmente é possível apontar: a investigação administrativa (realizada pela polícia, com a utilização do inquérito policial, ou por outros órgãos administrativos); a investigação legislativa, por intermédio das Comissões Parlamentares de Inquérito ${ }^{118}$; e a investigação realizada pelo Ministério Público ${ }^{119} 120$.

Embora o ordenamento jurídico brasileiro já tenha contemplado a possibilidade de exercer o juiz atividades de investigação ${ }^{121}$, não

116 “Art. 395. A denúncia ou queixa será rejeitada quando: I- for manifestamente inepta; II- faltar pressuposto processual ou condição para o exercício da ação penal; ou III- faltar justa causa para o exercício da ação penal."

${ }^{117}$ MARQUES, José Frederico. Elementos..., vol. 1., p. 153.

118 Previstas, no âmbito Federal, no artigo 58, § $3^{\circ}$, da Constituição Federal, e, no âmbito dos Estados, nas suas respectivas Constituições Estaduais.

119 A questão relativa aos poderes de investigação do Ministério Público é polêmica e seus pontos principais serão apresentados em item posterior.

${ }^{120}$ Havia também no Direito Brasileiro a investigação judicial, realizada no inquérito judicial previsto no Título VII, artigo 103 e seguintes, da antiga Lei de Falências, Decreto-lei n. 7.661/45, mas o novo diploma falimentar, a Lei n. 11.101/05, não mais previu a citada modalidade de investigação.

121 A antiga Lei de Falências (Decreto-lei n. 7.661/45) e a Lei de Combate ao Crime Organizado (Lei n. 9.034/95). 
mais se encontram em vigor normas que disciplinam a investigação realizada pelo magistrado, com o objetivo de preservar-se o princípio da imparcialidade do julgador.

Serão a seguir analisadas as principais modalidades de investigação e a sua relação com a publicidade.

\subsection{O inquérito policial e a publicidade}

Constitui o inquérito policial o instrumento de que se serve a polícia judiciária - polícia federal e polícia civil - ${ }^{122}{ }^{123}$ para a apuração de infrações penais, encontrando-se disciplinado nos artigos $4^{\circ}$ a 23 do Código de Processo Penal, Título II (Do inquérito policial).

Trata-se do instrumento que tem por função precípua a investigação de infrações penais, por meio do qual se prepara, instrui, a ação penal, com elementos indicativos de autoria e materialidade do ilícito.

${ }^{122}$ Artigo 144 , I e IV, $\S \S 1^{\circ}$ e $4^{\circ}$, da Constituição Federal.

${ }^{123}$ E. MAGALHÃES NORONHA destaca que a "Polícia judiciária atua após a prática do crime, colhendo elementos que o elucidam e evitando que desapareçam, para que mais tarde possa haver lugar a ação penal. Essa função é repressiva. Não obstante, é bem de ver que se cogita ainda de atividade administrativa. Trata-se de função investigatória destinada a auxiliar a Justiça". Magalhães nORonha, E. Curso de Processo Penal. 19. ed. São Paulo: Saraiva, 1989, p. 17. 
Segundo JOSÉ FREDERICO MARQUES é “um procedimento administrativo-persecutório de instrução provisória, destinado a preparar a ação penal" ${ }^{124}$.

FERNANDO DA COSTA TOURINHO FILHO salienta ainda a natureza escrita do inquérito ${ }^{125}$.

As regras do diploma processual penal sobre o inquérito regulamentam as diligências a serem adotadas pelas autoridades policiais na presidência do procedimento para a apuração de infrações penais e os poderes de que dispõem para o exercício de suas funções, bem como os prazos e deveres a serem observados em sua atividade.

O inquérito policial é, assim, procedimento com aspectos marcadamente inquisitivos, tendentes a assegurar a efetividade de sua função de apuração preparatória de uma ação penal.

Prepondera na doutrina a concepção de que as garantias processuais não se aplicam ao inquérito policial ${ }^{126}$.

A interpretação literal do artigo $5^{\circ}$, incisos LIV e LV, da Constituição Federal parece autorizar a referida concepção.

\footnotetext{
124 MARQUES, José Frederico. Elementos..., vol. 1., op. cit., p. 163. No mesmo sentido: magalhães noronha, E.. Curso de Processo Penal..., op. cit., p. 18.

${ }^{125}$ TOURINHO FILHO, Fernando da Costa. Processo Penal 1. São Paulo: Saraiva, 2006, p. 205.

${ }^{126}$ MARQUES, José Frederico. Elementos..., vol. 1, p. 163 e seguintes.
} 
Com efeito, dispõe o inciso LIV do artigo $5^{\circ}$ da Constituição Federal que "ninguém será privado da liberdade ou de seus bens sem o devido processo legal", e o inciso LV do referido artigo estabelece que "aos litigantes, em processo judicial ou administrativo, e aos acusados em geral são assegurados o contraditório e ampla defesa, com os meios e recursos a ela inerentes" (grifo nosso).

A ausência de qualquer referência explícita a investigações e investigados sugere a não atuação da cláusula do devido processo legal no inquérito policial.

Esta não é, todavia, a melhor interpretação.

É que o potencial comprometimento da posterior atuação das garantias processuais que pode decorrer de sua exclusão absoluta da fase investigatória, conduzindo a situações absurdas, como, p.ex., a da efetivação de prisão cautelar sem que o preso pudesse saber a razão da medida antes do encerramento da investigação e a possibilidade de serem decretadas, no curso da investigação, medidas que atinjam diretamente direitos e garantias fundamentais do investigado; e a interpretação sistemática do texto constitucional, à luz do princípio da igualdade (artigo $5^{\circ}$, caput, da Constituição Federal), que no processo repercute na idéia de "igualdade de armas no processo para as partes, ou par condicio" ${ }^{127}$, são razões suficientes para justificar a atuação, ainda que de forma parcial e pontual, das garantias do devido processo legal na fase investigatória. 
O posicionamento sustentado autoriza a conclusão de que no inquérito policial, desde que as informações colhidas apontem no sentido de que a infração penal foi cometida por um indivíduo determinado, este tem o direito de ser ouvido sobre os fatos ${ }^{128}$, bem como de, juntamente com o seu defensor, participar, ainda que sob a forma de requerimentos dirigidos à autoridade policial, das investigações e de ter acesso aos autos da investigação ${ }^{129}$.

Sustentando a possibilidade do exercício do direito de defesa ainda na fase investigatória, FLÁVIA RAHAL BRESSER PEREIRA argumenta que tal possibilidade decorre da cláusula do devido processo legal, havendo também da outras expressas previsões na Constituição acerca do exercício do direito de defesa na investigação policial, notadamente nos incisos LXII e LXIII do artigo $5^{\circ}$ da Constituição Federal ${ }^{130}$ :

LXII - a prisão de qualquer pessoa e o local onde se encontre serão comunicados imediatamente ao juiz competente e à família do preso ou à pessoa por ele indicada;

128 O próprio artigo $6^{\circ}$, inciso $\mathrm{V}$, do Código de Processo Penal, determina que a autoridade policial deverá “ouvir o indiciado, com observância, no que lhe fora aplicável, do disposto no Capítulo III do Título VII, deste Livro, devendo o respectivo termo ser assinado por 2 (duas) testemunhas que lhe tenham ouvido a leitura;", medida que, também adotada como parte de um método investigativo, possui valor na correta apuração dos fatos.

${ }^{129} \mathrm{O}$ artigo $7^{\circ}$, inciso XIV, da Lei n. 8.906/94 (Estatuto da Advocacia) estabelece ser direito do advogado "examinar em qualquer repartição policial, mesmo sem procuração, autos de flagrante e de inquérito, findos ou em andamento, mesmo sem procuração, quando não estejam sujeitos a sigilo, assegurada a obtenção de cópias, podendo tomar apontamentos”.

${ }^{130}$ RAHAL BRESSER PEREIRA, Flávia. A publicidade no processo penal brasileiro - Confronto com o direito à intimidade. Dissertação de mestrado em Direito Processual Penal apresentada na Universidade de São Paulo, no ano 2000, p. 190. 
LXIII - o preso será informado de seus direitos, entre os quais o de permanecer calado, sendo-lhe assegurada a assistência de família e de advogado.

MARTA SAAD também advoga a importância do direito de defesa na fase do inquérito policial, aduzindo que não são praticados no inquérito apenas atos de investigação, mas também atos de instrução criminal, alguns dos quais em caráter definitivo, bem como que, no curso da investigação, podem ser praticados atos que acarretem restrições a direitos fundamentais ${ }^{131}$.

No que se refere à relação entre a publicidade e o inquérito policial cabe inicialmente mencionar o predominante entendimento doutrinário no sentido de que o procedimento é eminentemente sigiloso.

E. MAGALHÃES NORONHA assim sustenta tal entendimento:

O inquérito, entre nós, tem caráter inquisitivo, gozando por isso a autoridade policial de discrição. Certo é que não se trata de arbítrio, tanto que ela está sujeita a prazos, não pode arquivar inquéritos etc. Mas suas atribuições são discricionárias; é ela que conduzirá a investigação preparatória e, conseqüentemente, lhe é facultado agir livremente dentro dos limites legais. Assim lhe é dado:

${ }^{131}$ SAAD, Marta. O Direito de Defesa no Inquérito Policial. São Paulo: Revista dos Tribunais, 2004, p. 198-200. 
indeferir requerimento de diligências do ofendido, seu representante legal e do indiciado (art. 17); assegurar o caráter sigiloso do inquérito, quando necessário (art. 20) e a incomunicabilidade do indiciado (art. 21) ${ }^{132}$.

FERNANDO DA COSTA TOURINHO FILHO também se posiciona no mesmo sentido, escrevendo sobre a natureza sigilosa do inquérito policial:

\begin{abstract}
Além de escrito ele ainda é sigiloso. Se o inquérito policial visa a investigação, a elucidação, a descoberta das infrações penais e das respectivas autorias, pouco ou quase nada valeria a ação da polícia judiciária senão pudesse ser guardado o necessário sigilo durante a sua realização. O princípio da publicidade, que domina o processo, não se harmoniza, não se afina com o inquérito policial. Sem o necessário sigilo, diz Tornaghi, o inquérito seria uma burla, um atentado ${ }^{133} 134$.
\end{abstract}

O caráter sigiloso do inquérito é extraído pela doutrina da interpretação do artigo 20 do Código de Processo Penal: “A autoridade

${ }^{132}$ MAGAlHÃES NORONHA, E.. Curso de..., cit. p. 21.

${ }^{133}$ TOURINHO FILHO, Fernando da Costa. Processo..., cit. p. 206.

134 Também ANTONIO SCARANCE FERNANDES sustenta que "Na fase do inquérito, deve a autoridade policial assegurar o sigilo necessário à elucidação do fato ou exigido pelo interesse da sociedade (art. 20 do CPP). Esse sigilo não pode, contudo, impedir o acesso de advogados aos autos de inquérito, que lhes é assegurado pelo artigo $7^{\circ}$, inciso XIV, do Estatuto da Ordem dos Advogados do Brasil”. SCARANCE FERNANDES, Antonio, Processo..., p. 73. 
assegurará no inquérito o sigilo necessário à elucidação do fato ou exigido pelo interesse da sociedade."

A norma em comento não permite, contudo, a conclusão de que o sigilo é característica do inquérito policial.

Com efeito, o artigo 20 do Código de Processo Penal apenas autoriza a autoridade policial a decretar o sigilo nas hipóteses em que este se mostre necessário à apuração da infração penal e de sua autoria.

Daí se pode concluir que o sigilo não é a regra e, portanto, característica do inquérito policial, mas, sim, a exceção à regra de publicidade para as hipóteses em que se revele necessário à elucidação do fato ou para atender o interesse social.

Além disso, o aludido artigo 20 do Código de Processo Penal deve ser interpretado em conformidade com a Constituição Federal de 1988, que, entre outras coisas, instituiu, no Capítulo VII (Da administração pública) do Título III (Da organização do Estado), mais precisamente no artigo 37, o princípio da publicidade, que se aplica, segundo o texto constitucional, à "administração pública direta e indireta de qualquer dos Poderes da União, dos Estados, do Distrito Federal e dos Municípios”.

CELSO ANTÔNIO BANDEIRA DE MELLO salienta que o princípio da publicidade consagra: 
o dever administrativo de manter plena transparência em seus comportamentos. Não pode haver em um Estado Democrático de Direito, no qual o poder reside no povo (art. $1^{\circ}$, parágrafo único, da Constituição), ocultamento aos administrados dos assuntos que a todos interessam, e muito menos em relação aos sujeitos individualmente afetados por alguma medida ${ }^{135}$.

Pois bem, encontrando-se as atividades da autoridade policial, entre as quais a de presidir o inquérito policial, subordinadas ao princípio da publicidade, é inexorável a conclusão sobre o caráter público, como regra, do referido procedimento de investigação, o qual poderá ser restringido nas hipóteses do artigo 20 do Código de Processo Penal.

Cabe, por fim, ponderar que, no seu aspecto interno, a publicidade revela-se sobremaneira importante no inquérito, pois ela condiciona o exercício do direito de defesa, de modo que, a partir do instante em que um feixe de indícios convirja para o suspeito como provável autor da infração penal, deve ter ele ciência do conteúdo do inquérito, a fim de que possa defender-se ${ }^{136}$.

\subsection{As investigações promovidas pelo Ministério Público e}

a publicidade

135 BAndeira De MELlo, Celso Antônio. Curso de Direito Administrativo. São Paulo: Malheiros, $21^{\text {a }}$ ed., 1999, p. 110.

${ }^{136}$ SAAD, Marta. O Direito de Defesa... op. cit. 272. 
Existe atualmente no Brasil grande discussão sobre a possibilidade de realizar o Ministério Público diretamente atividades de investigação criminal ${ }^{137}$.

Parte da doutrina e da jurisprudência sustenta que o poder investigatório do Ministério Público infere-se claramente de suas funções institucionais expressamente disciplinadas no artigo 129 da Constituição Federal.

Merecem inicialmente destaque as funções de:

Art. 129. São funções institucionais do Ministério Público:

I - promover, privativamente, a ação penal pública, na forma da lei;

II- zelar pelo efetivo respeito dos Poderes Públicos e dos serviços de relevância pública aos direitos assegurados nesta Constituição, promovendo as medidas necessárias a sua garantia.

Deflui, para tal corrente de pensamento, de tais atribuições o poder investigatório, visto que o Ministério Público é o titular privativo da ação penal e a instituição incumbida da fiscalização do exercício regular dos

${ }^{137}$ SCARANCE Fernandes, Antonio. Processo Penal Constitucional. . São Paulo: RT, 2005, p. 22-23. 
Poderes, bem como de seus mecanismos de controle, e a investigação criminal nada mais é do que meio que viabiliza ao Ministério Público a obtenção de elementos que propiciem o ajuizamento da ação penal e o desempenho de sua função fiscalizatória.

ALEXANDRE DE MORAES salienta que:

A erigir o Ministério Público como garantidor e fiscalizador da separação de poderes e, conseqüentemente, dos mecanismos de controles estatais (CF, ART. 129, II), o legislador constituinte conferiu à Instituição função de resguardo ao status constitucional do cidadão, armando-o de funções, garantias e prerrogativas que possibilitassem o exercício daquelas e a defesa destes.

Incorporou-se em nosso ordenamento jurídico, portanto, a pacífica doutrina constitucional norte-americana sobre a teoria dos poderes implícitos - inherent powers -, pela qual no exercício de sua missão constitucional enumerada, o órgão executivo deveria dispor de todas as funções necessárias, ainda que implícitas, desde que não expressamente limitadas (Myers vs. Estados Unidos - US 272 - 52, 118), consagrando-se, dessa forma, e entre nós aplicável ao Ministério Público, o reconhecimento de competências genéricas implícitas que possibilitem o exercício de sua missão constitucional, apenas sujeita às proibições e limites estruturais da Constituição Federal. 
Entre as competências implícitas, parece-nos que não poderia ser afastado o poder investigatório criminal dos promotores e procuradores, para que, em casos que entenderem necessário, produzam as provas necessárias para combater, principalmente, a criminalidade organizada e a corrupção, não nos parecendo razoável o engessamento do órgão titular da ação penal, que, contrariamente ao histórico da Instituição, teria cerceado seus poderes implícitos essenciais para o exercício de suas funções constitucionais expressas ${ }^{138}$.

Dispõe ainda o artigo 129 da Constituição Federal ser também função institucional do Ministério Público:

VI - expedir notificações nos procedimentos administrativos de sua competência, requisitando informações e documentos para instruí-los, na forma da lei complementar específica".

Pois bem, considerando que o inciso III menciona expressamente o inquérito civi1 ${ }^{139}$, entende-se que a locução "procedimentos administrativos de sua competência" refira-se ao procedimento criminal investigatório.

${ }^{138}$ MORAES, Alexandre de. Direito Constitucional. 20. ed. São Paulo: Atlas, p. 572.

139 Artigo 129, inciso III, da CF: "promover o inquérito civil e a ação civil pública, para a proteção do patrimônio público e social, do meio ambiente e de outros interesses difusos e coletivos". 
Infere-se também o poder investigatório da função disciplinada no inciso VII do dispositivo constitucional ora comentado:

VII - exercer o controle externo da atividade policial, na forma da lei complementar mencionada no artigo anterior".

Mais uma vez a investigação conduzida pelo Ministério Público consiste no meio indispensável para o exercício de tal atribuição.

É, por fim, necessária menção ao inciso IX:

IX - exercer outras funções que lhe forem conferidas, desde que compatíveis com sua finalidade, sendo-lhe vedada a representação judicial e a consultoria jurídica de entidades públicas.

A atividade de investigação mostrar-se-ia compatível com a finalidade da instituição, notadamente com a atribuição relativa à promoção da ação penal pública.

Um último argumento refere-se ao fato de que a Constituição Federal não atribuiu a qualquer órgão ou instituição, com exclusão de outros, a função de investigação criminal.

Numa outra perspectiva, o direito que o Ministério Público possui de investigar defluiria até mesmo do devido processo legal, notadamente da cláusula do contraditório. Na medida em que a aludida cláusula compreende 
o direito das partes a, produzindo provas, influírem no resultado do processo, a apontada cláusula também legitima que as partes obtenham, por meio de investigação, provas, pena de esvaziar-se o conteúdo do contraditório, que, além de seu valor de garantia, também possui relevante valor epistemológico na busca da verdade judicial ${ }^{140}$.

Outra parte da doutrina e da jurisprudência entende que o Ministério Público não possui poderes de investigação criminal.

Sustenta, tal corrente de pensamento, que o Ministério Público não dispõe de atribuição para a promoção de investigações criminais.

Em primeiro lugar, em razão da ausência de norma constitucional que expressamente autorize as investigações criminais pelo Ministério Público ${ }^{141}$, estabelecendo, a Constituição Federal, atribuição exclusiva da polícia judiciária para, por meio do inquérito policial, promover a apuração de infrações penais e de sua autoria.

Em segundo lugar, por também não haver normas infraconstitucionais possibilitando o desempenho da atividade de investigação criminal pelo Ministério Público ${ }^{142}$.

\footnotetext{
${ }^{140}$ TARUFFO, Michele. La prova dei fatti giuridici. Milano, Giuffrè, 1992, p. 400-409. Sobre a importância epistemológica do contraditório no acertamento dos fatos.

141 TUCCI, Rogério Lauria. Ministério Público e Investigação Criminal. São Paulo: Saraiva, 2004, p. 74-76.

${ }^{142}$ Idem, p. 76-78.
} 
Em terceiro lugar, porque não disporia o Ministério Público de infraestrutura para a realização de investigações criminais ${ }^{143}$.

Em quarto lugar, porquanto a promoção das investigações criminais pelo Ministério Público, instituição à qual se atribuiu a titularidade para a ação penal, poderia comprometer as relevantes garantias processuais do contraditório e da ampla defesa.

\section{Segundo ROGÉRIO LAURIA TUCCI:}

(...) mesmo para os que entendem ser admissível, apenas, a efetividade da defesa no âmbito da investigação criminal, no qual não haveria lugar para o contraditório, a realização desta pelo Ministério Público implica, inequivocamente, inadmissível desequilíbrio entre as partes na persecutio criminis, sendo a infração penal de ação pública ${ }^{144}$.

Para os que aceitam a legitimidade do Ministério Público para promover investigações criminais, resta analisar a relação destas com a publicidade.

As mesmas ideias apresentadas no item anterior (2. a publicidade e o inquérito policial) sobre a atuação das garantias processuais no

\footnotetext{
143 TUCCI, Rogério Lauria. Ministério Público... op. cit., p. 78-79.

${ }^{144}$ Ibidem, p. 82-83
} 
inquérito policial aplicam-se nas investigações criminais do Ministério Público.

As garantias do devido processo legal devem atuar também nas investigações do Ministério Público, ainda que parcialmente e pontualmente, a fim de evitar o comprometimento de seu funcionamento no processo penal e eventuais prejuízos irreparáveis ao exercício do direito de defesa do investigado e, consequentemente, à tutela de sua liberdade.

A publicidade também é a regra nas investigações do Ministério Público, embora tal conclusão não decorra dos artigos 5, LV, e 93, IX, da Constituição Federal, que regulamentam apenas a publicidade no processo.

De serem repetidas, neste ponto, as considerações sobre o princípio da publicidade da administração pública, que também se aplica aos órgãos do Ministério Público.

Mas não é só.

A Resolução n. 13, de 02 de outubro de 2006, do Conselho Nacional do Ministério Público ${ }^{145}$ disciplinou, no âmbito do Ministério Público, a instauração e tramitação do procedimento investigatório criminal. E o

145 O Conselho Nacional do Ministério Público é o órgão de controle externo da atividade do Ministério Público e de seus órgãos, tendo a sua composição e atribuições disciplinadas no artigo 130-A da Constituição Federal, acrescentado pela Emenda Constitucional n. 45, de 8 de dezembro de 2004. 
referido diploma regulamenta especificamente a publicidade em tal procedimento, nos seguintes moldes:

\section{CAPÍTULO IV}

\section{DA PUBLICIDADE}

Art. 13. Os atos e peças do procedimento investigatório criminal são públicos, nos termos desta Resolução, salvo disposição legal em contrário ou por razões de interesse público ou conveniência da investigação.

Parágrafo único. A publicidade consistirá:

I - na expedição de certidão, mediante requerimento do investigado, da vítima ou seu representante legal, do Poder Judiciário, do Ministério Público ou de terceiro diretamente interessado;

II - no deferimento de pedidos de vista ou de extração de cópias, desde que realizados de forma fundamentada pelas pessoas referidas no inciso I ou a seus advogados ou procuradores com poderes específicos, ressalvadas as hipóteses de sigilo;

III - na prestação de informações ao público em geral, a critério do presidente do procedimento investigatório 
criminal, observados o princípio da presunção de inocência e as hipóteses legais de sigilo.

Art. 14. O presidente do procedimento investigatório criminal poderá decretar o sigilo das investigações, no todo ou em parte, por decisão fundamentada, quando a elucidação do fato o interesse público exigir, garantida ao investigado a obtenção, por cópia autenticada de depoimento que tenha prestado e dos atos de que tenha, pessoalmente, participado.

Como se vê, a regra, no procedimento investigatório criminal do Ministério Público, é a publicidade, com restrições por razões de interesse público. Mas, segundo a regulamentação do Conselho Nacional do Ministério Público, que se coaduna com o princípio da publicidade administrativa, o regime de publicidade é diferente para o investigado e demais interessados na investigação, e ao público em geral, sendo aquele mais amplo, justamente para viabilizar a atuação das garantias processuais.

\subsection{As investigações legislativas e a publicidade}

As investigações legislativas são realizadas por intermédio das comissões parlamentares de inquérito, previstas na Constituição Federal ${ }^{146}$ e nas Constituições dos Estados.

${ }^{146}$ Reza o artigo $58, \S 3^{\circ}$, da Constituição Federal: “As comissões parlamentares de inquérito, que terão poderes de investigação próprios das autoridades judiciais, além de outros previstos nos 
JOSÉ AFONSO DA SILVA ensina que as comissões parlamentares de inquérito:

são organismos que desempenharam e desempenham papel de grande relevância na fiscalização e controle da Administração, mas que tiveram sua organização e suas tarefas consideravelmente tolhidas no regime da Constituição revogada. Era esta uma de suas marcas autoritárias. Foram bastante prestigiadas pela Constituição vigente, a ponto de receber poderes de investigação próprios das autoridades judiciárias, além de outros previstos nos regimentos das respectivas Casas. Não há limitação à sua criação. A Câmara dos Deputados e o Senado Federal, em conjunto ou separadamente, poderão criar tantas comissões parlamentares de inquérito quantas julgarem necessárias ${ }^{147}$.

ALEXANDRE DE MORAES, baseando-se na jurisprudência do Supremo Tribunal Federal, ressalva que, embora exista previsão de poderes próprios das autoridades judiciárias, as comissões parlamentares de inquérito não possuem poderes que impliquem a relativização de direito fundamental nas hipóteses em que a Constituição Federal exige, para tanto, a intervenção judicial. Desse modo, refere o autor que as comissões parlamentares de

regimentos das respectivas Casas, serão criadas pela Câmara dos Deputados e pelo Senado Federal, em conjunto ou separadamente, mediante requerimento de um terço de seus membros, para a apuração de fato determinado e por prazo certo, sendo suas conclusões, se for o caso, encaminhadas ao Ministério Público, para que promova a responsabilidade civil ou criminal dos infratores."

${ }^{147}$ AFONSO DA SILVA, José. Curso de Direito Constitucional Positivo. 30. ed. São Paulo: Malheiros, 2008, p. 516. 
inquérito não poderão: decretar quaisquer hipóteses de prisão, salvo as prisões em flagrante delito; determinar a aplicação de medidas cautelares, tais como indisponibilidade de bens, arrestos, sequestro, hipoteca judiciária, proibição de ausentar-se da comarca ou país; e proibir ou restringir a assistência jurídica aos investigados ${ }^{148}$.

No campo da publicidade, não há no ordenamento constitucional e infraconstitucional norma alguma disciplinando a questão no âmbito das investigações promovidas pelas comissões parlamentares de inquérito ${ }^{149}$.

O princípio da publicidade administrativa, que, repise-se, se aplica a todos os Poderes, determina, todavia, que as investigações criminais realizadas pelas Comissões Parlamentares de Inquérito pautem-se também pela publicidade como regra, podendo o sigilo apenas ser excepcionalmente decretado para a tutela de outros valores envolvidos na investigação - interesse social, necessidade específica para o sucesso da apuração etc. - que, no caso concreto, justifiquem a medida.

Pondera, com razão, FLÁVIA RAHAL, que no campo das investigações parlamentares:

Delicada mostra-se a questão, no entanto, dada a natureza, eminentemente política da CPI a ressaltar outra das finalidades da publicidade, que diz com a função política

\footnotetext{
${ }^{148}$ MORAES, Alexandre de. Direito..., op. cit., p. 404-405.

${ }^{149}$ RAHAL BRESSER PEREIRA, Flavia. A publicidade..., op. cit., p. 230.
} 
do próprio processo penal e a consecução da paz pública por seu intermédio. O sigilo dos atos das comissões parlamentares mostra-se incompatível com esse quadro, devendo sua aplicação ser excepcional e se fundar em interesses e direitos de relevância, a justificar a inacessibilidade do povo ao seu funcionamento ${ }^{150}$.

É certo, entretanto, que o regime de publicidade que vem sendo aplicado atualmente pelas comissões parlamentares de inquérito instaladas, viabilizando a transmissão direta pelos meios de comunicação das sessões realizadas, além de transformar o ato praticado em verdadeiro "palco" de exposição utilizado pelos integrantes da comissão como "palanque eleitoral", com o evidente prejuízo à finalidade da investigação que daí pode emergir, representa significativo risco à dignidade, intimidade, vida privada, imagem e honra dos demais "atores" envolvidos - investigados, vítimas, testemunhas etc.

\subsection{A limitação da publicidade nas investigações}

No que diz respeito à publicidade externa, a questão relacionada à possibilidade de limitação desta em virtude de sua colisão com o direito à intimidade e com outros direitos fundamentais constitui objeto do capítulo 8 do presente trabalho.

\footnotetext{
${ }^{150}$ RAHAL BRESSER PEREIRA, Flavia. A publicidade..., op. cit., p. 232. A questão também é abordada por LACAVA, Thaís Aroca Datcho. O sigilo nas Comissões Parlamentares de Inquérito e as garantias individuais. in Sigilo no Processo Penal - Eficiência e Garantismo. Vários autores, coordenada por ANTONIO SCARANCE FERNANDES, JOSÉ RAUL GAVIÃO DE ALMEIDA e MAURÍCIO ZANOIDE DE MORAES. São Paulo: RT, 2008, p. 115-137.
} 
Quanto à publicidade interna, tomando por premissa a ideia de que as garantias processuais projetam-se para a fase investigatória, é inexorável a conclusão de que, a partir do momento em que surge durante as investigações suspeita de autoria da infração penal, também emerge para o suspeito o direito de ter conhecimento sobre os fatos apurados.

Em virtude da importância da defesa técnica, o advogado também possui a prerrogativa de acesso aos autos da investigação, estabelecendo o artigo $7^{\circ}$, inciso XIV, da Lei n. 8.906/94 ser direito do advogado "examinar em qualquer repartição policial, mesmo sem procuração, autos de flagrante e de inquérito, findos ou em andamento, ainda que conclusos à autoridade, podendo copiar peças e tomar apontamentos".

É certo, todavia, que o sigilo de algumas medidas, relacionadas, por exemplo, a um pedido de busca e apreensão ou a uma representação à autoridade judicial para a decretação da quebra de sigilo bancário e financeiro, deve se impor, inclusive ao acusado e ao seu advogado, sob pena de inviabilizar-se completamente a apuração da infração penal, daí porque se entende que, aplicado o método da proporcionalidade para a solução do conflito entre o direito de defesa e o interesse social na apuração de infrações penais, é possível que se decrete o sigilo na investigação, em situações excepcionais e até que se efetive a medida ${ }^{151}$.

A recente Súmula Vinculante n. 14 do Supremo Tribunal Federal também dispôs sobre a questão:

151 ZANOIDE DE MORAES, Maurício. Publicidade... op. cit., p. 42. 
“É direito do defensor, no interesse do representado, ter acesso amplo aos elementos de prova que, já documentados em procedimento investigatório realizado por órgão com competência de polícia judiciária, digam respeito ao exercício do direito de defesa."

A redação da Súmula parece, numa análise inicial, ter inviabilizado completamente o sigilo na investigação em relação ao advogado, mas uma apreciação mais percuciente do enunciado autoriza a conclusão de que não se proibiu, em situações excepcionais, o sigilo para a efetivação de medidas tendentes à obtenção de $\operatorname{provas}^{152}$, que, documentadas nos autos correspondentes à investigação, poderão ser acessadas pelo acusado e seu advogado, adotando-se um regime de sigilo, semelhante ao adotado na Lei n. 9.296/96, que disciplina a interceptação das comunicações telefônicas e em sistemas de informática e telemática, de qualquer natureza, para prova em investigação e em instrução processual penal.

152 Sobre a noção de obtenção de prova: SILVA, Eduardo Araujo da. Crime Organizado: procedimento probatório. São Paulo: Atlas, 2003, p. 64-66. 


\section{6- O PROCESSO PENAL E A PUBLICIDADE:}

\subsection{A publicidade na fase do processo}

Após a propositura da ação penal, com o oferecimento da denúncia ou da queixa-crime, o regime jurídico da publicidade sofre sensíveis modificações.

Se na fase investigatória a publicidade pode sofrer maiores restrições a fim de conferir efetividade ao seu escopo de apuração da infração penal e de sua respectiva autoria - mas sempre se tendo presente a noção de necessidade para que se opere a limitação -, na fase do processo a publicidade deve imperar, sofrendo restrições apenas nas hipóteses previstas no texto constitucional e nos termos da lei.

A publicidade interna é praticamente irrestringível, sob pena de absoluto comprometimento à atuação das demais garantias do devido processo legal, com evidente prejuízo para os atores processuais atingidos pela restrição, "pois isso significaria diminuir-lhes as oportunidades de participação efetiva nas atividades processuais" $" 153$.

As hipóteses de restrição à publicidade referem-se, quase que exclusivamente, à noção de publicidade externa, nas balizas constitucionais de necessidade da defesa da intimidade e do interesse social (artigo $5^{\circ}$, LX, da Constituição Federal), na forma da lei.

${ }^{153}$ GOMES FILHO, Antonio Magalhães. A motivação..., op. cit. p. 50. 
É a publicidade externa, direta e indireta, que representa maior risco a outros valores constitucionais tutelados no processo, sobretudo os atinentes à proteção da intimidade, da vida privada, da imagem e da honra dos indivíduos.

A publicidade no processo penal e a possibilidade de sua restrição também se encontram disciplinadas no plano infraconstitucional, e o estudo da legislação referente a tal disciplina será o objeto dos próximos itens.

\subsection{O artigo 792, caput, e $§ 1^{\circ}$, do Código Processo Penal}

As primeiras normas infraconstitucionais a merecerem destaque encontram-se no artigo 792, caput, e $\S 1^{\circ}$, do Código de Processo penal (Livro VI - Disposições Gerais), que possuem a seguinte redação:

As audiências, sessões e os atos processuais serão, em regra, públicos e se realizarão nas sedes dos juízos e tribunais, com assistência dos escrivães, do secretário, do oficial de justiça que servir de porteiro, em dia e hora certos ou previamente designados.

$\S 1^{\circ}$ Se da publicidade da audiência, da sessão ou do ato processual, puder resultar escândalo, inconveniente grave ou perigo de perturbação da ordem, o juiz, ou o tribunal, câmara, ou turma, poderá, de ofício ou a requerimento da parte ou do Ministério Público, determinar que o ato seja realizado a portas fechadas, limitando o número de pessoas que possam estar presentes. 
FLÁVIA RAHAL ressalta que:

(...) o caput do artigo 792 consagra a publicidade ampla ou geral, enquanto o $\S 1^{\circ}$, a excepcional publicidade restrita, com a presença das partes e de seus representantes legais. Registramos aqui que fazemos uso da expressão "publicidade restrita" por ser, usualmente, adotada na doutrina, a despeito de sua impropriedade técnica. "Público" é algo que está à disposição de qualquer pessoa; se há pessoas proibidas de acesso, já não há publicidade. Mantém-se o caráter público de um ato se, por exceção, pequena parcela do universo é dele excluída (os menores de 18 anos; os que perturbarem a ordem dos trabalhos; o réu cuja presença influir no depoimento da testemunha, nos termos do artigo 217 do CPP; as pessoas que o juiz, no exercício da polícia das audiências, deliberar excluir do recinto), mas, ele se desnatura se, ao contrário, a regra seja o segredo e a exceção sua revelação a algumas pessoas (o acusado, as partes, os interessados etc. $)^{154}$.

Como se pode perceber, o legislador processual penal não estabeleceu com precisão os casos em que a restrição da publicidade é possível, preferindo utilizar-se de expressões de conteúdo abrangente, conferindo aparente margem de discricionariedade bastante elástica ao juiz, ao autorizá-1o a determinar o sigilo para a realização de determinado ato com o objetivo de evitar escândalo, inconveniente grave ou perigo de perturbação da ordem decorrentes da publicidade.

${ }^{154}$ RAHAL, Flávia, A publicidade..., op. ci. p. 274. 
É certo, outrossim, que o citado dispositivo, notadamente em virtude de seus contornos pouco precisos, não conferiu "cheque em branco" para que o juiz, a seu bel prazer, possa impingir a restrição de um direito fundamental de índole política e processual, pois isso equivaleria à eliminação de um mecanismo de controle do exercício do poder promovido por um dos sujeitos sobre o qual incide o controle, o que constitui rematado absurdo.

As normas em comento devem, por óbvio, ser interpretadas em consonância com a disciplina constitucional da publicidade, com outros valores constitucionais envolvidos no tema e com a regulamentação constante dos tratados internacionais que fazem parte do ordenamento brasileiro, bem como de forma sistemática, ou seja, em conjunto com outras normas infraconstitucionais relativas à publicidade no processo.

De se lembrar que a restrição da liberdade fora das hipóteses previstas nas normas constitucionais implica a nulidade do ato praticado em sigilo, por força do disposto expressamente no artigo 93, inciso IX, da Constituição Federal ${ }^{155}$.

Trata-se, de acordo com os ensinamentos de ADA PELLEGRINI GRINOVER, ANTONIO SCARANCE FERNANDES $\mathrm{e}$

\footnotetext{
155 “todos os julgamentos dos órgãos do Poder Judiciário serão públicos, e fundamentadas todas as decisões, sob pena de nulidade, podendo a lei limitar a presença, em determinados atos, às próprias partes e a seus advogados, ou somente a estes, em casos nos quais a preservação do direito à intimidade do interessado no sigilo não prejudique o interesse público à informação" (grifamos).
} 
ANTONIO MAGALHÃES GOMES FILHO, de nulidade absoluta, por violação a garantia constitucional estabelecida no interesse público ${ }^{156}$.

Outro aspecto relativo ao artigo 792 do Código de Processo Penal liga-se à existência de regulamentação deficiente sobre a abrangência da restrição à publicidade decretada nos autos, apenas havendo menção sobre a possibilidade de vir a ser o ato praticado a portas fechadas, limitando-se o número de pessoas presentes.

\subsection{O artigo 155 do Código de Processo Civil}

A apontada deficiência remete o intérprete, por força do disposto no artigo $3^{\circ}$ do referido diploma legal ${ }^{157}$, à disciplina da publicidade no processo civil, a fim de viabilizar o suprimento das lacunas do diploma processual penal.

A regulamentação da publicidade no processo civil é feita pelo artigo 155, que se insere na Seção I (Dos atos em geral) do Capítulo I (Da

\footnotetext{
${ }^{156}$ Assim se posicionam os autores sobre o tema: "Sendo a norma constitucional-processual norma de garantia, estabelecida no interesse público (supra, n. 2), o ato processual inconstitucional, quando não juridicamente inexistente, será sempre absolutamente nulo, devendo a nulidade ser decretada de ofício, independentemente de provocação da parte interessada. (Sobre nulidades absolutas e relativas, ver retro, cap. I, n. 2). É que as garantias constitucionais-processuais, mesmo quando aparentemente postas em benefício da parte, visam em primeiro lugar ao interesse público na condução do processo segundo as regras do devido processo legal. Resulta daí que o ato processual, praticado em infringência à norma ou ao princípio constitucional de garantia, poderá ser juridicamente inexistente ou absolutamente nulo; não há espaço, nesse campo, para atos irregulares sem sanção, nem para nulidades relativas." (GRINOVER, Ada Pellegrini; SCARANCE FERNANDES, Antonio; GOMES FILHO, Antonio Magalhães. As nulidades no processo penal. 3. ed. São Paulo: Malheiros, 1994, p. 21.
}

157 Artigo $3^{\circ}$ do CPP: “A lei processual penal admitirá interpretação extensiva e aplicação analógica, bem como o suplemento dos princípios gerais de direito". 
forma dos atos processuais) do Título V (Dos atos processuais), nos seguintes termos:

Art. 155. Os atos processuais são públicos. Correm, todavia, em segredo de justiça os processos:

I - em que o exigir o interesse público;

II - que dizem respeito a casamento, filiação, separação dos cônjuges, conversão desta em divórcio, alimentos e guarda de menores.

Parágrafo único. O direito de consultar os autos e de pedir certidões de seus atos é restrito às partes e a seus procuradores. O terceiro, que demonstrar interesse jurídico, pode requerer ao juiz certidão do dispositivo da sentença, bem como de inventário e partilha resultante do desquite.

Assim é que, vislumbrando a necessidade de restrição a publicidade, deverá o juiz, por intermédio de decisão motivada, especificar, com fundamento na legislação processual ora comentada - artigo 792 do CPP c.c. o artigo 155 do $\mathrm{CPC}$-, os motivos que o levaram à relativização do direito 
fundamental (artigo 93, inciso IX, da Constituição Federal) e a sua abrangência ${ }^{158}$.

\subsection{A prova testemunhal e a publicidade}

No que se refere às declarações do ofendido, a Lei $n$. 11.690/08 trouxe importante modificação, concernente à possibilidade de restrição da publicidade do processo para a preservação da intimidade, vida privada, honra e imagem da vítima, estabelecendo nova redação para o artigo 201 do Código de Processo Penal, ao qual acrescentou o seguinte $\S 6^{\circ}$ :

\footnotetext{
$\S 6^{0} \quad \mathrm{O}$ juiz tomará as providências necessárias à preservação da intimidade, vida privada, honra e imagem do ofendido, podendo, inclusive, determinar o segredo de justiça em relação aos dados, depoimentos e outras informações constantes dos autos a seu respeito para evitar sua exposição aos meios de comunicação.
}

Andou bem, a nosso sentir, o legislador infraconstitucional ao estabelecer restrição à publicidade externa do processo, com o objetivo de preservar a intimidade e a vida privada daquele que, além de já ter sido vítima

\footnotetext{
${ }^{158}$ FLÁVIA RAHAL discorre sobre a impossibilidade de obterem as partes ou seus representantes legais cópias do processo sob segredo de justiça, por não explicitada no artigo 155 do CPC, nem no Estatuto da Advocacia e da Ordem dos Advogados do Brasil (Lei n. 8.906/94), que, no artigo $7^{\circ}$, inciso XIII, "inclui entre os direitos do advogado o de, mesmo sem procuração examinar autos 'que não estejam sujeitos a sigilo, assegurada a obtenção de cópias', mas, silencia com relação ao procurador da parte nos autos cobertos pelo regime". (RAHAL, Flávia, A publicidade..., cit. p. 280-281).
} 
do delito que motivou a instauração do processo, ainda possuir o dever de prestar esclarecimento sobre os fatos.

ANTONIO MAGALHÃES GOMES FILHO assevera que:

a preservação da intimidade, vida privada, honra e imagem do ofendido (art. 201, $\S \quad 6^{\circ}$ ) constitui salutar especificação, na legislação ordinária, do preceito constitucional do art. 5. ${ }^{\circ}, \mathrm{X}$, da CF. Por isso, a sua violação implica responsabilidade civil por danos materiais e morais ${ }^{159}$.

A restrição coaduna-se com a disciplina constitucional da publicidade processual, que, como visto, admite limitação para a preservação da intimidade, mas cabe advertir que, dada a importância da publicidade salientada no presente trabalho, o magistrado deverá realizar ponderação, a fim de que estabeleça a restrição apenas quando houver proporcionalidade da medida.

\subsection{O Tribunal do Júri e a publicidade}

Fundamenta-se o Tribunal do Júri na idéia de participação

159 GOMES FILHO, Antonio Magalhães, PRADO, Geraldo, GALLUZI DOS SANTOS, Leandro, BOtTini, Pierpaolo Cruz, in As Reformas no Processo Penal...op. cit., comentário feito por Antonio Magalhães sobre a nova redação do artigo 201 do CPPB, realçando a importância do princípio da imparcialidade e acerca da discussão desencadeada, p. 281. 
popular nos julgamentos ${ }^{160}$.

Surgiu na Inglaterra, onde até hoje continua a existir em virtude de seu peculiar sistema jurisdicional, o mesmo ocorrendo nos Estados Unidos.

Foi transplantado para alguns dos países da Europa Continental, de tradição romanística, num momento histórico em que representava "reação" ao modo de julgar dos juízes nomeados pelos governantes absolutistas, que nem sempre desfrutavam de independência para o exercício da missão de julgar ${ }^{161}$. Ali, portanto, nasceu em "berço democrático".

Atualmente, à exceção dos países que adotam o sistema da common law, praticamente não mais existe o Tribunal do Júri. Na Alemanha, na Itália e na França não existem mais Tribunais de Júri, havendo apenas algumas formas de participação popular nos escabinados (participação conjunta de magistrados e cidadãos nas decisões). Na América Latina, não mais existe no México; na Argentina, apesar de possuir previsão constitucional, nunca existiu $^{162}$.

Em suma, hoje é um instituto bem característico do Direito Brasileiro, no qual possui a conotação de liberdade pública, direito individual previsto no artigo $5^{\circ}$, inciso XXXVIII, da CF.

\footnotetext{
${ }^{160}$ MARQUES, José Frederico. A instituição do Júri. São Paulo, Saraiva, 1963, p. 9.

${ }^{161}$ Ibidem, p. 2-8.

${ }^{162}$ Ibidem, p. 8-9.
} 
Foi criado pela Lei de 18 de junho de 1822 com a competência restrita aos crimes de imprensa, sendo composto por 24 juízes de fato, cidadãos escolhidos "dentre os homens bons, honrados, inteligentes e patriotas" $" 163$.

Sobrevieram amplas competências para o Tribunal do Júri no Código de Processo Criminal do Império (1832), período em que julgava quase todos os crimes. Havia o júri de acusação, composto por 23 pessoas que decidiam sobre pronúncias e impronúncias e o júri de sentença, integrado por 12 pessoas que julgavam os casos. Existia ainda pena de morte, exigindo-se, contudo, para a sua imposição, decisões unânimes.

O sistema foi modificado na reforma $1841 / 1842$, por meio da qual se aboliu o júri de acusação, sendo ainda reduzidas as competências do colegiado. Na reforma estabeleceu-se que a imposição da pena de morte dependia apenas de $2 / 3$ dos votos. Em 1850, houve nova redução de competências do júri, as quais foram restabelecidas na reforma processual de 1871.

Em 1890, além do Estadual, que já existia, foi criado o Júri Federal.

A Constituição Federal de 1891 manteve a instituição do Júri no capítulo dos direitos e garantias individuais. 
Em 1898 e 1923 foram novamente reduzidas as competências do Júri.

A Constituição Federal de 1934 retirou a instituição do Júri do referido capítulo (direitos e garantias individuais), mas ainda reconheceu a sua existência.

A Constituição Federal de 1937 nada dispôs sobre o Júri, mas o decreto 167 de 1938, regulando o Júri, evidenciou a sua existência, embora "enfraquecendo" a instituição, introduzindo a possibilidade de apelação sobre o mérito, assim eliminando a soberania dos veredictos.

A Constituição Federal de 1946 reforçou o Júri, restaurando a soberania, com base num ideal de democracia, delineando-o, no plano constitucional, de forma muito semelhante à da instituição que conhecemos, inclusive no tocante à competência (crimes dolosos contra a vida), reinserindoo ainda no capítulo dos direitos e garantias individuais ${ }^{164}$.

A mesma estrutura foi mantida pelas Constituições de 1967 e de 1988 .

Por que a competência do Tribunal do Júri gira em torno dos crimes contra a vida e, em especial, do homicídio?

164 MARQUES, José Frederico. A instituição..., op. cit., p. 8-9. 
Segundo NELSON HUNGRIA:

O homicídio é o tipo central dos crimes contra a vida e é o ponto culminante na orografia dos crimes. É o crime por excelência. É o padrão da delinqüência violenta ou sanguinária, que representa como que uma reversão atávica às eras primevas, em que a luta pela vida, presumivelmente, se operava com o uso normal dos meios brutais e animalescos. É a mais chocante violação do senso moral médio da humanidade ${ }^{165}$.

Justifica-se o julgamento de tais crimes pelo Tribunal do Júri, de um lado, no aspecto garantista de que o indivíduo que comete o homicídio e outros crimes contra a vida, às vezes impelido por motivação desprovida da reprovabilidade que é inerente a outros comportamentos ilícitos, está sujeito a consequências tais que somente deve ser punido se condenado pelo "senso comum"; de outro lado, na noção de que o julgamento pelo Júri funciona como um "termômetro social" dos comportamentos admitidos e censurados em determinada comunidade, valendo, neste ponto, ressaltar o aspecto da repercussão dos julgamentos do Júri, especialmente em pequenas comunidades, e o aspecto do "dinamismo" das decisões, tomadas sempre de acordo com os valores atuais da comunidade ${ }^{166}$.

Como já se disse, o Tribunal do Júri está atualmente previsto

${ }^{165}$ HUNGRiA, Nelson. Comentários ao Código Penal. Vol. 5. Rio de Janeiro: Forense, p. 25.

166 Existem vários críticos da instituição do Júri, entre os quais se insere JOSÉ FREDERICO MARQUES, para quem os juízes, melhor providos de conhecimentos jurídicos e criminológicos, julgam melhor. MARQUES, José Frederico. A instituição..., op. cit., p. 2-8. 
no $\operatorname{artigo~} 5^{\circ}$, inciso XXXVIII, da Constituição Federal:

XXXVIII - é reconhecida a instituição do júri, com a organização que lhe der a lei, assegurados:

a) a plenitude de defesa;

b) o sigilo das votações;

c) a soberania dos veredictos;

d) a competência para o julgamento dos crimes dolosos contra a vida.

Considerando que o Tribunal do Júri fundamenta-se na ideia de julgamento popular, a noção de publicidade é dela indissociável, atuando com vigor em todas as fases do processo ${ }^{167}$.

A Constituição Federal, contudo, estabeleceu "sigilo das votações", fazendo-o com o objetivo de evitar qualquer influência externa na livre formação individual do convencimento do jurado, bem como na

167 O procedimento nos processos submetidos a julgamento pelo Tribunal do Júri é bifásico, havendo uma fase preliminar, perante o juiz singular, a fim de avaliar a existência de indícios de autoria e prova da materialidade do crime, e uma fase de julgamento pelo colegiado (artigos 406 a 497 do Código de Processo Penal, Capítulo II (Do procedimento relativo aos processos da competência do Tribunal do Júri), com as alterações introduzidas pela Lei n. 11.689 de 2008). 
exteriorização de tal convencimento por intermédio do seu voto.

Trata-se, pois, de parcial restrição constitucional à publicidade, que se justifica no interesse da justiça, na concepção de que, desprovidos os jurados de conhecimentos jurídicos e criminológicos, o sigilo das votações é o método mais eficiente e eficaz para que o processo atinja um resultado justo, sob a premissa de que a decisão decorrerá da soma da livre manifestação individual de vontade de sete julgadores.

A restrição, portanto, seja em razão de sua expressa previsão constitucional, seja por compreender razões teleológicas, seja por se referir a apenas um momento processual específico, não compromete a publicidade processual, nos seus aspectos político e processual.

Como se não bastasse, a restrição também se ampara nos diplomas internacionais sobre direitos humanos vigentes no ordenamento jurídico brasileiro, notadamente no artigo 14-1 do Pacto dos Direitos Civis e Políticos de 1966, que a autoriza, entre outras hipóteses, "na medida em que isto seja estritamente necessário na opinião da justiça, em circunstâncias específicas, nas quais a publicidade venha a prejudicar os interesses da justiça", e no artigo $8^{\circ}$ da Convenção Americana sobre Direitos Humanos, que estabelece: "O processo penal deve ser público, salvo no que for necessário para preservar os interesses da justiça".

Regulamentando o sigilo das votações previsto constitucionalmente, dispõe o artigo 485 do Código de Processo Penal, com as modificações introduzidas pela Lei n. 11.689 de 2008: 
Art. 485. Não havendo dúvida a ser esclarecida, o juiz presidente, os jurados, o Ministério Público, o assistente, o querelante, o defensor do acusado, o escrivão e o oficial de justiça dirigir-se-ão à sala especial a fim de ser procedida a votação.

$\S 1^{\circ} \mathrm{Na}$ falta de sala especial, o juiz presidente determinará que o público se retire, permanecendo somente as pessoas mencionadas no caput deste artigo.

$\S 2^{\circ} \mathrm{O}$ juiz presidente advertirá as partes de que não será permitida qualquer intervenção que possa perturbar a livre manifestação do Conselho e fará retirar da sala quem se portar inconvenientemente.

Nota-se, portanto, claramente que a concepção de uma "sala especial" para a realização da votação decorre justamente da preocupação em se evitar alguma influência externa que possa comprometer a livre manifestação de vontade dos julgadores.

Além disso, o legislador processual penal também cuidou para que não houvesse influências recíprocas na livre formação do convencimento do jurado e em sua exteriorização, estabelecendo, de um lado, a incomunicabilidade dos jurados sobre os fatos objeto do processo e, de outro, o 
sigilo dos $\operatorname{votos}^{168}$ :

Art. 466, $\S 1^{\circ} \mathrm{O}$ juiz presidente também advertirá os jurados de que, uma vez sorteados, não poderão comunicar-se entre si e com outrem, nem manifestar sua opinião sobre o processo, sob pena de exclusão do Conselho e multa, na forma do $\S 2^{\circ}$ do art. 436 deste Código.

$\S 2^{\circ}$ A incomunicabilidade será certificada nos autos pelo oficial de justiça.

Art. 487. Para assegurar o sigilo do voto, o oficial de justiça recolherá em urnas separadas as cédulas correspondentes aos votos e as não utilizadas.

A existência de uma "sala especial", conhecida como "sala secreta" antes das modificações introduzidas pela Lei n. 11.689/08, é, contudo, alvo de críticas doutrinárias.

RENÉ ARIEL DOTTI sustenta que a existência da "sala secreta" é:

${ }^{168}$ HERMÍNIO ALBERTO MARQUJES PORTO sustenta que o sigilo das votações cuida-se, na realidade, de um princípio da função do jurado. MARQUES PORTO, Hermínio Alberto. Júri Procedimentos e aspectos do julgamento - Questionários. 9. ed. São Paulo: Malheiros, 1998, p. 55. 
(...) um anacronismo de nosso sistema que não mais se justifica em face dos tempos modernos que exigem o debate de infinitas questões de interesse público e quando os meios de comunicação e o exercício da liberdade de informação permitem que os jurados tomem conhecimento antecipado de muitos detalhes do processo que irão $\operatorname{examinar}^{169}$.

A crítica não conduz, a nosso sentir, à conclusão de que a realização da votação em "sala especial" afronte a garantia constitucional da publicidade.

É que a publicidade restrita, nessa hipótese, fundamenta-se na ideia de preservação dos jurados contra influências externas no momento da votação, propiciando-lhes as condições ideais para que, com ânimo calmo e refletido $^{170}$, possam exteriorizar a sua convicção, sem preocupações com a presença do público, às vezes numeroso, e da mídia, por intermédio da manipulação dos votos, cujo sigilo também corre risco ante a presença de grande número de pessoas no local da votação e da potencial utilização de recursos tecnológicos aptos a desvendarem-lhe o teor.

Justifica-se, pois, na própria restrição constitucional que preserva o sigilo das votações e no interesse da administração da justiça, uma

169 DOTTI, René Ariel. A publicidade dos julgamentos e a "sala secreta" do júri. Revista dos Tribunais, vol. 677, de março de 1992, São Paulo: RT, p. 330-337.

170 CABRAL SARAIVA, Wellington. A Regra do Segredo nas ações penais do Tribunal de Justiça do Distrito Federal: Inconstitucionalidade, in Boletim dos Procuradores da República n. 27, julho de 2000, p. 28-29. 
das facetas do interesse social ${ }^{171}$.

E mais: não se trata de restrição absoluta, mas, apenas, restrição à publicidade externa, de modo que o Ministério Público e o defensor do réu podem acompanhar e fiscalizar a transparência da votação.

A crítica de RENÉ ARIEL DOTTI permite, porém, que se constate outro sério problema que será posteriormente tratado neste estudo, concernente à possibilidade de informações veiculadas pelos meios de comunicação sobre o processo interferirem previamente no convencimento dos jurados.

${ }^{171}$ FLÁVIA RAHAL revela a existência de julgados entendendo que a "sala secreta" não viola a garantia da publicidade no processo. RAHAL, Flávia. A publicidade..., op. cit., p. 328. 


\section{7- A GARANTIA DA PUBLICIDADE COMO “PRINCÍPIO” E A PROPORCIONALIDADE:}

\subsection{Nota Introdutória}

O estudo da publicidade no processo e, especialmente, da possibilidade de estabelecimento de limitações a ela, em razão da necessidade de serem prestigiados outros valores relevantes contemplados no ordenamento jurídico, deve, de acordo com abalizada doutrina, necessariamente passar pela compreensão da natureza normativa da publicidade ${ }^{172}$.

Dessa forma, seria importante, para se avaliar qual a natureza normativa da publicidade, estabelecer se esta se cuida de princípio ou de regra.

\subsection{As modalidades normativas: princípios e regras}

Para ROBERT ALEXY, os princípios constituem mandados de otimização, ordenando que algo seja realizado na melhor medida possível, tendo em conta as possibilidades jurídicas e fáticas, tratando-se, portanto, de

\footnotetext{
172 Sobre a importância da distinção entre princípios e regras para o fim de a solução de problemas relativos à possibilidade de restrições a direitos fundamentais, v. ALEXY, Robert. Teoria dos Direitos Fundamentais, 5. ed. alemã. Tradução de Virgílio Afonso da Silva. São Paulo: Malheiros, 2008, p. 90.
} 
normas que podem ou não ser cumpridas em diferentes graus, ao passo que as regras contêm determinações que somente podem ser cumpridas ou não ${ }^{173}$.

O conflito entre princípios resolver-se-ia, assim, por meio da ponderação entre os seus diferentes "pesos" diante de uma situação concreta, de modo a prevalecer o princípio com maior peso para a solução do conflito no caso específico, sem que tal ponderação afete a validade do princípio não $\operatorname{aplicado}^{174}$.

O conflito entre regras, por outro lado, solucionar-se-ia no plano da validade, de maneira que, havendo duas regras aparentemente incidindo sobre uma hipótese fática, mas com consequências jurídicas distintas, uma delas deve ser declarada inválida. Outra hipótese de solução do conflito entre regras consiste na inserção de uma cláusula de exceção, que eliminaria o conflito $^{175}$.

Nessa linha de raciocínio, é bem aceita na doutrina a ideia de que a Constituição Federal contempla, no âmbito da disciplina dos direitos fundamentais, normas veiculando definições precisas e definitivas, com a

\footnotetext{
${ }^{173}$ ALEXY, Robert. Teoria dos Direitos... op. cit., p. 103-104.

${ }^{174}$ Ibidem, p. 93-94.

${ }^{175}$ Ibidem, p. 92-93.
} 
estrutura de regras, e normas dotadas de abertura semântica e forte carga valorativa, que se veiculam por meio de princípios $^{176}$.

\subsection{A publicidade como "princípio"}

Algumas peculiaridades do dispositivo que, no Título da Constituição Federal, o qual trata Dos Direitos e Garantias Fundamentais, disciplina a publicidade no processo trazem, contudo, ao intérprete dificuldades no seu enquadramento normativo.

Com efeito, como já visto neste trabalho, dispõe o artigo $5^{\circ}$, LX, da Constituição Federal que "a lei só poderá restringir a publicidade dos atos processuais quando a defesa da intimidade ou o interesse social o exigirem".

Pois bem, uma análise inicial da referida norma pelo intérprete pode conduzir à conclusão de que se está diante de uma regra, visto que o comando veicula precisamente que os atos processuais são públicos, ressalvando a publicidade para as hipóteses previstas em cláusula de exceção, a serem veiculadas por meio de lei.

Em outras palavras, a restrição da publicidade em hipóteses distintas das estabelecidas em lei para a tutela da intimidade e do interesse social é inconstitucional, o que aparenta tratar-se de regra.

176 SOUZA LiMA, Carolina Alves de. Aborto e Anencefalia - Direitos Fundamentais em Colisão. Curitiba: Juruá, 2008, p. 140. 
A análise mais aprofundada da norma, contudo, notadamente das hipóteses contidas na cláusula de exceção, que se referem à defesa da intimidade e do interesse social, que se cuida, na realidade, de outros direitos fundamentais também disciplinados no texto constitucional, mas com grande abertura semântica ${ }^{177}$, a qual, na concepção de ROBERT ALEXY, autorizaria classificá-los como princípios, traz sérias dúvidas sobre se a publicidade realmente pode ser enquadrada como regra, não se podendo ademais olvidar que a publicidade processual também se relaciona com a publicidade da administração pública disciplinada no artigo 37 da Constituição Federal, expressamente erigida à condição de princípio.

Em suma, a dificuldade de enquadrar a publicidade como regra ou princípio, de acordo com a teoria da norma proposta por ROBERT ALEXY, traz sérios questionamentos sobre como solucionar os conflitos entre o direito fundamental relativo à publicidade processual e os direitos compreendidos na referida cláusula de exceção contida no artigo $5^{\circ}$, LX, da Constituição Federal, especialmente quanto às hipóteses e à extensão das limitações à publicidade processual.

Os referidos questionamentos, segundo nos parece, encontram solução na moderna teoria das normas proposta HUMBERTO ÁVILA, segundo a qual as espécies normativas passam pela ideia de dissociação em alternativas inclusivas ${ }^{178}$.

\footnotetext{
${ }^{177}$ Cfr. artigo $5^{\circ}$, caput e inciso X, da Constituição Federal.

178 ÁVILA, Humberto. Teoria dos Princípios. Malheiros: São Paulo, 2007, p. 68-69.
} 
Pois bem, estabelece inicialmente ÁVILA a seguinte distinção entre princípios e regras:

\begin{abstract}
As regras são normas imediatamente descritivas, primariamente retrospectivas e com pretensão de decidibilidade e abrangência, para cuja aplicação se exige a avaliação da correspondência, sempre centrada na finalidade que lhes dá suporte ou nos princípios que lhes são axiologicamente sobrejacentes, entre a construção conceitual da descrição normativa e a construção conceitual dos fatos ${ }^{179}$.
\end{abstract}

Os princípios são normas imediatamente finalísticas, primariamente prospectivas e com pretensão de complementaridade e de parcialidade, para cuja aplicação se demanda uma relação entre o estado de coisas a ser promovido e os efeitos decorrentes da conduta havida como necessária à sua promoção ${ }^{180}$.

Esclarecendo os conceitos supramencionados, ensina que as normas são imediatamente descritivas, pois estipulam obrigações, permissões e proibições mediante a descrição da conduta a ser cumprida, com a previsão de um comportamento, enquanto os princípios são normas finalísticas, visto que estabelecem um estado de coisas cuja promoção gradual depende dos efeitos decorrentes da adoção de comportamentos a ele necessários, tratando-se, pois,

\footnotetext{
179 ÁVILA, Humberto. Teoria dos...op. cit., p. 78.

${ }^{180}$ Ibidem, p. 78-79.
} 
de normas que determinam a realização de um fim juridicamente relevante. Distinguem-se, portanto, regras e princípios, quanto ao modo como prescrevem o comportamento ${ }^{181}$.

Regras e princípios diferenciam-se ainda quanto à justificação que exigem, de modo que a interpretação e a aplicação das regras demandam, por um lado, uma avaliação da correspondência entre a construção conceitual dos fatos e a construção conceitual da norma e a finalidade que lhe dá suporte. A interpretação e a aplicação dos princípios, por outro lado, impõe uma avaliação da correlação entre o estado de coisas posto como fim e os efeitos decorrentes da conduta havida como necessária ${ }^{182}$.

Distinguem-se, por fim, no que diz respeito ao modo como contribuem para a decisão. As normas possuem a pretensão de produzir uma solução específica para o conflito entre razões, abrangendo todos os aspectos relevantes para a decisão. São, pois, decisivas e abarcantes. Os princípios apenas abrangem parte dos aspectos relevantes para uma decisão, não tendo a pretensão de produzir uma solução específica, apenas contribuindo, aliados a outras razões, para a decisão. São, portanto, primariamente complementares e preliminarmente parciais ${ }^{183}$.

\footnotetext{
181 ÁVILA, Humberto. Teoria... op. cit. 180-81.

${ }^{182}$ Idem.

${ }^{183}$ Idem.
} 
Nenhuma das apontadas distinções elimina, para ÁVILA, a possibilidade de ponderação entre regras como método de interpretação e aplicação destas ${ }^{184}$.

O doutrinador argumenta que a ponderação, ou seja, o sopesamento de razões e contrarrazões que culminam com a decisão de interpretação, não se trata de método privativo de aplicação dos princípios. Contrariando o entendimento de ROBERT ALEXY, segundo o qual o conflito de regras soluciona-se pela declaração de invalidade de uma das regras ou pela abertura de exceção a uma das regras, restringindo-se a ponderação à solução do conflito entre princípios, realizada por meio da atribuição de peso maior a um deles, ÁVILA sustenta que pode haver solução de conflito entre regras, sem que estas percam a sua validade, por meio da atribuição de peso maior a uma delas.

O autor fornece dois exemplos para ilustrar o seu posicionamento:

(...) uma regra do Código de Ética Médica determina que o médico deve dizer para seu paciente toda a verdade sobre sua doença, e outra estabelece que o médico deve utilizar todos os meios disponíveis para curar seu paciente. Mas como deliberar o que fazer no caso em que dizer a verdade ao paciente sobre sua doença irá diminuir as chances de cura, em razão do abalo emocional daí decorrente? O médico deve dizer ou omitir a verdade? Casos hipotéticos

184 ÁVILA, Humberto. Teoria... p. 52. 
como esse não só demonstram que o conflito entre regras não é necessariamente estabelecido em nível abstrato, mas pode surgir no plano concreto, como ocorre normalmente com os princípios. Esses casos também indicam que a decisão envolve uma atividade de sopesamento entre razões.

(...) uma regra proíbe a concessão de liminar contra a Fazenda Pública que esgote o objeto litigioso (art. $1^{\circ}$ da Lei 9.494/1997). Essa regra proíbe ao juiz determinar por medida liminar, o fornecimento de remédios pelo sistema de saúde a quem deles necessitar para viver. Outra regra, porém, determina que o Estado deve fornecer, de forma gratuita, medicamentos excepcionais para pessoas que não puderem prover as despesas com os referidos medicamentos (art. $1^{\circ}$ da Lei estadual 9.908/1993). Essa regra obriga a que o juiz determine, inclusive por medida liminar, o fornecimento de remédios pelo sistema de saúde a quem deles necessitar para viver. Embora essas regras instituam comportamentos contraditórios, uma determinando o que a outra proíbe, elas ultrapassam o conflito abstrato mantendo sua validade. Não é absolutamente necessário declarar a nulidade de uma das regras, nem abrir exceção a uma delas. Não há exigência de colocar uma regra dentro e outra fora do ordenamento jurídico. O que ocorre é um conflito concreto entre as regras, de tal sorte que o julgador deverá atribuir um peso maior a uma das duas, em razão da finalidade que cada uma delas visa a preservar: ou prevalece a finalidade de preservar a vida do cidadão, ou se sobrepõe a finalidade de garantir a intangibilidade da destinação já dada pelo Poder 
Público às suas receitas. Independentemente da solução a ser dada - cuja análise é ora impertinente -, trata-se de um conflito concreto entre regras, cuja solução, sobre não estar no nível da validade, e sim no plano da aplicação, depende de uma ponderação entre as finalidades que estão em jogo ${ }^{185}$.

HUMBERTO ÁVILA ainda concebe uma terceira modalidade normativa, a dos postulados normativos, que se trata de normas imediatamente metódicas, estruturantes da interpretação e aplicação de princípios e regras, mediante a exigência, mais ou menos específica, de relações entre elementos com base em critérios, incluindo na aludida categoria a razoabilidade, a proporcionalidade etc. ${ }^{186}$

Prosseguindo na análise da natureza das normas, ÁVILA sustenta a possibilidade de coexistirem, em virtude de um mesmo dispositivo, espécies normativas distintas, de modo que um ou mais dispositivos podem servir como ponto de referência para a construção de regras, princípios e postulados ${ }^{187}$ :

Um ou vários dispositivos, ou mesmo a implicação lógica deles decorrente, pode experimentar uma dimensão

\footnotetext{
185 ÁVILA, Humberto. Teoria... op. cit., p. 53-54.

${ }^{186}$ Ibidem, p. 181-182

${ }^{187}$ Ibidem, p. 68-69.
} 
imediatamente comportamental (regra), finalística (princípio) e/ou metódica (postulado) ${ }^{188}$.

Exemplificando o seu pensamento, o autor assevera que a exigência de lei em sentido formal para a instituição ou aumento de tributos pode ser examinada como regra, como princípio e como postulado:

Como regra, porque condiciona a validade da criação ou aumento de tributos à observância de um procedimento determinado que culmine com a aprovação de uma fonte normativa específica - a lei. Como princípio, porque estabelece como devida a realização dos valores de liberdade e de segurança jurídica. E como postulado, porque vincula a interpretação e a aplicação à lei e ao Direito, preexcluindo a utilização de parâmetros alheios ao ordenamento jurídico ${ }^{189}$.

Pois bem, segundo pensamos, a norma constitucional que disciplina a publicidade como direito fundamental também autoriza que dela possam inferir-se princípio, regra e postulado.

A regra da publicidade condiciona a validade de sua restrição à observância de um procedimento determinado que resulte na aprovação de

\footnotetext{
188 ÁVILA, Humberto. Teoria... op. cit., p. 69.

${ }^{189}$ Idem.
} 
uma lei, vedando ainda o estabelecimento de limitações que não se refiram à tutela da intimidade e do interesse processual.

O princípio da publicidade estabelece como devida a realização do valor publicidade, seja na sua função de garantia política de fiscalização pelo público do exercício do poder jurisdicional e das atividades a ele relacionadas, seja na sua função de garantia processual.

O postulado da publicidade, como no exemplo trazido por ÁVILA, restringe a interpretação e a aplicação da publicidade e de suas limitações à lei e ao Direito, vedando a utilização de parâmetros alheios ao ordenamento jurídico.

Nenhuma ressalva possuímos, todavia, em relação à utilização da terminologia "princípio da publicidade", consagrada pela doutrina, com referência às espécies normativas relacionadas à publicidade processual disciplinada constitucionalmente, dada a acepção mais abrangente que a noção de princípio também possui ${ }^{190}$.

Postas as premissas relacionadas à natureza normativa multifacetada da publicidade, decorrente do acolhimento da proposta de dissociação em alternativas inclusivas das modalidades normativas, e à ponderabilidade de quaisquer espécies normativas, abrangendo a possibilidade de ponderação para a solução de conflitos concretos entre princípios e de

190 Denilson Feitoza Pacheco assevera que a "ideia de princípio abrange as outras, pois a noção de princípio pode conter subprincípios, regras e postulados necessários à promoção de seu fim", in PACHECO, Denilson Feitoza. O princípio da proporcionalidade no Direito Processual Penal Brasileiro. Rio de Janeiro: Lúmen Júris, 2007. 
conflitos concretos entre regras, entendemos que o surgimento de conflitos entre a publicidade e outros princípios e regras constitucionais, notadamente as normas relativas à tutela da intimidade e do interesse social, admitindo ponderação, haverão de ser dirimidos pelo postulado da proporcionalidade.

\subsection{A publicidade e postulado da proporcionalidade}

HUMBERTO ÁVILA ensina que a noção de proporção confunde-se com a própria noção imemorial de Direito, que tem a função de atribuir a cada um a sua proporção, perpassando todos os ramos do Direito ${ }^{191}$, mas adverte que a ideia de proporção em suas mais variadas manifestações não se confunde com o postulado da proporcionalidade, que:

(...) se aplica apenas a situações em que há uma relação de causalidade entre dois elementos empiricamente discerníveis, um meio e um fim, de tal sorte que se possa proceder aos três exames fundamentais: o da adequação (o meio promove o fim?), o da necessidade (dentre os meios disponíveis e igualmente adequados para promover o fim, não há outro meio menos restritivo do(s) direito(s) fundamentais afetados?) e o da proporcionalidade em sentido estrito (as vantagens trazidas pela promoção do

191 ÁVILA, Humberto. Teoria..., p. 160-161. 
fim correspondem às desvantagens provocadas pela adoção do meio? $)^{192}$.

Consubstancia-se a proporcionalidade numa forma de interpretar o ordenamento jurídico nas situações de conflito de direitos fundamentais ${ }^{193}$.

Trata-se, na visão de DENILSON FEITOZA PACHECO, de "norma imediatamente metódica, que estrutura a interpretação e aplicação de enunciados normativos que impliquem intervenções em direitos fundamentais, mediante a exigência específica de relações e critérios determinados"194, compondo-se pela idoneidade (adequação), necessidade e proporcionalidade stricto sensu como princípios cuja finalidade é a promoção de estado de coisas em que as medidas legislativas, judiciais e administrativas sejam adequadas, necessárias e proporcionais stricto sensu relativamente aos direitos fundamentais $^{195}$.

O referido doutrinador menciona em sua obra diversas posições sobre o fundamento jurídico da proporcionalidade, citando autores que a extraem de específicos dispositivos constitucionais, que a qualificam como manifestação do Princípio do Estado de Direito, que lhe atribuem a condição de princípio independente, que a explicam como implicação lógica e normativa dos princípios, que a definem como postulado básico de contenção dos excessos do Poder Público, que a fundamentam no princípio do devido

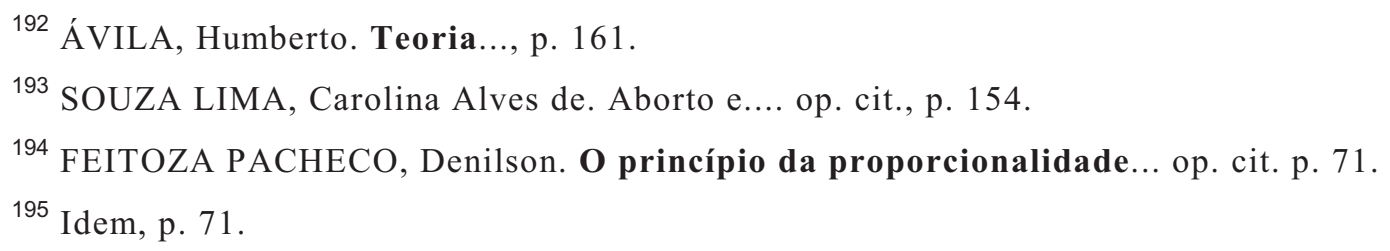


processo legal, que a reconhecem como postulado normativo aplicativo, o qual viabiliza a interpretação e a aplicação em sua máxima realização dos diversos direitos tutelados em um ordenamento, por vezes antagônicos, adotando esta última posição, acrescida da ideia de que, além de um método de aplicação das normas, a porporcionalidade também é implicação lógica do caráter jurídico da Constituição como norma rígida hierarquicamente superior, de maneira que as normas constantes do ordenamento jurídico não podem apresentar descompasso em relação aos valores constitucionalmente contemplados ${ }^{196}$, posicionamento que também adotamos no presente trabalho.

O postulado da proporcionalidade compreende, como já visto, como método de aplicação das normas, observado o seu aspecto de constitucionalidade, o exame da adequação, da necessidade e da proporcionalidade em sentido estrito da promoção de um direito fundamental em detrimento de outro.

A noção de adequação compreende a ideia de que o intérprete e o aplicador do direito devem considerar que o meio utilizado possa atingir a finalidade almejada.

Com o objetivo de analisar a relação de adequação, impõe-se considerar se a medida, abstrata e geralmente, viabiliza que seja atingido o fim visado.

${ }^{196}$ FEITOZA PACHECO, Denilson. O princípio da proporcionalidade... op. cit. p. 75-90. 
Não é importante, na análise da adequação, avaliar qual o meio quantitativamente mais adequado, qualitativamente melhor ou probabilisticamente mais seguro, o que pode prejudicar a escolha, devendo tal apreciação ser efetuada por ocasião da verificação da proporcionalidade em sentido estrito ${ }^{197}$.

A análise da necessidade, por seu turno, passa, inicialmente, pela consideração da existência de mais de um meio igualmente adequado para que se atinja o fim visado e, num segundo momento, pela escolha, entre as diversas medidas aptas a atingir a finalidade perseguida, daquela que seja menos lesiva para o direito a ser restringido ${ }^{198}$.

Grande dificuldade surge em hipótese na qual os distintos meios adequados mostram-se eficazes, mas em diferentes graus, à promoção do objetivo almejado, situação em que o intérprete deverá, no passo seguinte, estabelecer relação entre os diferentes graus em que os meios distintos promovem o fim visado e os diferentes graus de restrição que estes propiciam ao direito a ser limitado, para que, por meio de ponderação, possa escolher a medida necessária ${ }^{199}$.

\footnotetext{
${ }^{197}$ Humberto Ávila explica que a "imediata exclusão de um meio que não é o mais intenso, o melhor e o mais seguro para atingir o fim impede a consideração a outros argumentos que podem justificar a escolha. Esses outros argumentos não devem, por isso, ser analisados no exame de adequação, mas no exame de proporcionalidade em sentido estrito(...)" in ÁVILA, Humberto. Teoria..., p. 166.

${ }^{198}$ SOUZA LIMA, Carolina Alves de. Aborto e.... op. cit., p. 157.

199 ÁVILA, Humberto. Teoria..., p. 172.
} 
A proporcionalidade em sentido estrito consubstancia-se na ponderação de bens, momento em que se solucionam as colisões entre os direitos fundamentais.

A análise da proporcionalidade realiza-se por meio da apreciação da importância do objetivo colimado, da intensidade da restrição ao direito fundamental e, por fim, da justificação da restrição do direito em prol da realização do fím pretendido ${ }^{200}$.

O aplicador do direito atribui, assim, diferentes "pesos" entre os valores compreendidos pelo fim visado e os abrangidos pelo direito a ser restringido, para que, após complexa avaliação quantitativa, qualitativa e probabilística do meio em relação à finalidade perseguida, bem como do grau de restrição do direito atingido, consiga estabelecer a possibilidade de intervenção no direito fundamental.

DENILSON FEITOZA PACHECO ensina, no âmbito do processo penal, que:

\begin{abstract}
A contrariedade fundamental entre um princípio instrumental punitivo e um princípio instrumental garantista é da essência de uma persecução criminal constitucionalizada. Conforme vimos, quanto mais intensamente se procura demonstrar a existência do fato delituoso e sua autoria (princípio fundamental punitivo),
\end{abstract}

200 SOUZA LIMA, Carolina Alves de. Aborto e.... op. cit., p. 158. 
mais se distancia da garantia dos direitos fundamentais, quanto mais intensamente se garantem os direitos fundamentais (princípio instrumental garantista), mais difícil se torna a coleta e produção de provas que poderão demonstrar a existência do fato delituoso e sua autoria.

A ponderação efetuada na aplicação do subprincípio da proporcionalidade em sentido estrito à persecução criminal tem como referência central essa contrariedade fundamental, a qual também poderia ser denominada colisão fundamental. Portanto, essa colisão ou contrariedade fundamental é um aspecto peculiar da aplicação do princípio da proporcionalidade ao processo penal lato sensu ${ }^{201}$.

Deve, portanto, o intérprete, em face do mencionado conflito entre o princípio instrumental punitivo e o princípio instrumental garantista no âmbito do processo penal, servir-se do postulado da proporcionalidade em busca do equilíbrio entre a eficiência e o garantismo no processo penal.

A publicidade, tendo como pano de fundo o processo penal lato sensu, traz à tona diversas situações em que os interesses tutelados na persecução penal entram em conflito, bem como outras em que direitos fundamentais não imediatamente relacionados aos interesses tutelados no processo, como o direito à intimidade, são também atingidos.

${ }^{201}$ FEITOZA PACHECO, Denilson. O princípio da proporcionalidade... op. cit. p. 212-13. 
O equilíbrio entre a publicidade, os demais valores tutelados no processo e a proteção da intimidade deverá, adotado o método da proporcionalidade, ser buscado pelo aplicador do direito nas diferentes situações em que tais interesses entrem em conflito.

Algumas das hipóteses de conflito entre os aludidos valores o presente trabalho pretende analisar. 


\section{8- A LIMitaÇÃO DA PUBLICIDAde PARA A DEFESA DA INTIMIDADE - O DIREITO À INTIMIDADE E A LIBERDADE DE EXPRESSÃO E DE INFORMAÇÃO}

\subsection{A proteção dos bens jurídicos de índole pessoal}

A dignidade humana constitui o fundamento da proteção dos bens jurídicos de índole pessoal, cujo reconhecimento vem sendo cada vez mais difundido nos ordenamentos jurídicos contemporâneos ${ }^{202}$, compreendendo, entre outros, o direito à intimidade, o direito à vida privada, o direito à imagem e o direito à honra ${ }^{203}$.

Os referidos direitos encontram-se, no nosso ordenamento jurídico, tutelados no artigo $5^{\circ}$, inciso $X$, da Constituição Federal que assim preceitua: "são invioláveis a intimidade, a vida privada, a honra e a imagem das pessoas, assegurado o direito à indenização pelo dano material ou moral decorrente de sua violação".

Impõe-se, a seguir, a apresentação de algumas noções conceituais sobre os referidos direitos de índole pessoal, bem como a sua diferenciação, estabelecendo-se ainda os seus aspectos mais relevantes para o posterior cotejo com a liberdade de expressão e de informação e a publicidade no processo penal.

\footnotetext{
202 COSTA ANDRADE, Manuel da Liberdade de Imprensa e Inviolabilidade Pessoal - Uma Perspectiva Jurídico-Criminal. Coimbra: Coimbra Editora, 1996, p. 13.

${ }^{203}$ Ibidem, p. 15.
} 


\subsubsection{O direito à intimidade e à vida privada}

Foram concebidas, a intimidade e a vida privada, como esferas de atuação do indivíduo com a exclusão de terceiros ${ }^{204}$, condicionantes do livre desenvolvimento da personalidade do ser humano, cada vez mais ameaçado com novas realidades sociais do mundo contemporâneo, as quais:

vêm levando, de um lado, à interferência crescente na esfera da vida privada por parte do poder público - tanto no exercício quotidiano do poder de polícia quanto no campo da atividade judiciária - e, de outro, à maior possibilidade de terceiros se intrometerem no âmbito da intimidade das pessoas. Para isso vêm concorrendo os artefatos derivados da inovação tecnológica, como teleobjetivas, gravadores de minúsculas dimensões, aparelhos de interceptação telefônica, computadores ${ }^{205}$.

E o sigilo, na lição de TÉRCIO SAMPAIO FERRAZ JÚNIOR, constitui o conteúdo dos direitos à intimidade e privacidade, pois que se trata da faculdade atribuída ao sujeito de "constranger os outros ou de resistir-lhes", assim inviabilizando eventuais ingerências externas na esfera de exclusividade ${ }^{206}$.

\footnotetext{
${ }^{204}$ LAFER, Celso. A Reconstrução dos Direitos Humanos: Um diálogo com o pensamento de Hannah Arendt. São Paulo: Companhia das Letras, 2006, p. 239-40.

${ }^{205}$ Ibidem, p. 240.

${ }^{206}$ SAMPAIO FerRaZ JÚNIOR, Tércio. Liberdade de Informação e Privacidade ou o Paradoxo da Liberdade. O Cinqüentenário da Declaração Universal dos Direitos do
} 
A privacidade/intimidade lato sensu, que abrange as ideias de intimidade e de privacidade stricto sensu, corresponde à necessidade de entrincheiramento do homem contemporâneo nos espaços de ação e interação pessoais ${ }^{207}$.

Compreende a proteção do indivíduo contra a ingerência de terceiros em eventos que somente digam respeito à própria vida daquele ou a de seus familiares ${ }^{208}$.

MANUEL DA COSTA ANDRADE, com fundamento em doutrina alemã, explica que a personalidade humana projeta-se em três graus distintos ${ }^{209210}$.

Cuida-se da Teoria dos Três Graus, que subdivide a projeção da personalidade do indivíduo nas esferas da intimidade, da privacidade e do público.

A esfera da intimidade consubstancia-se em área nuclear inviolável, propiciando o livre desenvolvimento da personalidade. Relaciona-se

Homem, organizado por Alberto do Amaral Júnior e Cláudia Perrone-Moisés. São Paulo: Edusp, 1999, p. 385-93.

207 COSTA ANDRADE, Manuel da... op. cit., p. 88.

${ }^{208}$ Idem, p. 92.

${ }^{209}$ Idem., p. 95-96.

${ }^{210}$ A doutrina brasileira, com base na alemã, também estabeleceu divisão entre as esferas na quais se desenvolve a personalidade do indivíduo. PAULO JOSÉ DA COSTA JÚNIOR foi o precursor do tema em obra que merece referência: COSTA JÚNIOR, Paulo José. O direito de estar só: tutela penal da intimidade. São Paulo: RT, 1970. 
a aspectos da vida do indivíduo que somente se relacionam e interessam a ele próprio, dizendo com o modo de ser da pessoa e com o seu direito de estar só, de maneira que não comporta restrições com base em ponderações realizadas por meio do postulado da proporcionalidade ${ }^{211}$.

Todas as pessoas, até as públicas ou notórias, possuem irrestrito direito à proteção da intimidade estrito senso ${ }^{212}$.

Já a privacidade estrito senso abrange os atos da vida da pessoa que se relacionam ao seu círculo mais restrito de relacionamento, no âmbito familiar e profissional.

No âmbito da privacidade, o indivíduo também tem interesse no segredo, mas a proteção deste depende da maior ou menor expressão do indivíduo aos holofotes da publicidade, bem como da inexistência de outro interesse com maior dimensão de "peso" 213 .

Com efeito, a privacidade comporta restrição em prol da promoção de outro direito fundamental mais relevante. Alguns atos da vida profissional do indivíduo, por exemplo, poderiam ser desvendados, até pela imprensa, em virtude da necessidade de apuração de ilícitos ${ }^{214}$.

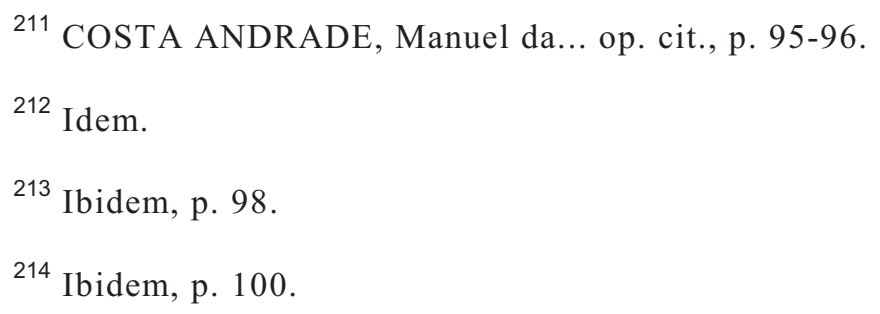


A esfera do público, por seu turno, refere-se aos atos do indivíduo no âmbito da coletividade, em relação aos quais a pessoa não pretende segredo, não se encontrando, pois, no âmbito de proteção que a intimidade e a privacidade demandam.

\subsubsection{O direito à imagem}

O direito à imagem relaciona-se à proteção do indivíduo contra a indevida gravação, registro, utilização ou divulgação de sua imagem. Embora se sustente que a proteção da imagem derive da proteção da intimidade, parece-nos mais correta a ideia de que se trata, na realidade, de expressão da autonomia individual, porquanto somente a pessoa pode autorizar que se grave registre, utilize ou divulgue a sua imagem ${ }^{215}$.

Existe, porém, estreita relação entre o direito à imagem e a intimidade, visto que apenas as imagens relativas à intimidade são invioláveis, ao passo que a utilização de imagens relativas às outras esferas dependem de ponderação ${ }^{216}$, de modo que a violação injustificada ao direito à imagem implicará invariavelmente a violação à intimidade e à vida privada.

No aspecto que interessa ao nosso estudo, releva notar que, no âmbito do processo em sentido amplo, a proteção à imagem encontra-se abrangida pela tutela constitucional da intimidade insculpida nos artigos $5^{\circ}$, inciso LX, e 93, inciso IX, ambos da Constituição Federal.

\footnotetext{
${ }^{215}$ COSTA ANDRADE, Manuel da... op. cit., p. 132-34.

${ }^{216}$ Ibidem, p. 138.
} 


\subsubsection{O direito à honra}

MANUEL DA COSTA ANDRADE, desvinculando a noção de honra dos conceitos fáticos que a assentam em elementos descritivos, como a opinião ou sentimento de uma pessoa sobre o seu próprio valor (honra subjetiva) e a representação que as pessoas têm sobre o valor de outra (reputação ou bom nome), assevera que a honra representa a merecida ou fundada pretensão de respeito da pessoa no contexto das relações de comunicação e interação social em que é chamada a viver, tratando-se de conceito normativo, variável no tempo e no espaço ${ }^{217}$.

A honra de uma pessoa pode ver-se atingida pela imputação de um conceito ofensivo à sua dignidade ou pela imputação de fatos infamantes, verdadeiros ou não.

A imputação de conceito ofensivo à dignidade da pessoa ou a imputação a ela de fatos infamantes não verdadeiros são sempre coibidos pelo direito, configurando, inclusive, infrações penais, quase nunca admitindo ponderações $^{218}$.

A tutela da honra não se confunde, pois, com a da intimidade.

Somente é possível estabelecer-se alguma ligação entre a tutela da honra e a da intimidade, na hipótese de divulgação de fatos

${ }^{217}$ COSTA ANDRADE, Manuel da... op. cit., p. 79-81.

218 Vislumbra-se a possibilidade de ponderação na hipótese de retorsão imediata a ofensa injuriosa. 
verdadeiros infamantes, mas que digam respeito às esferas de proteção da intimidade e da vida privada.

Em tais situações, a proteção à honra, como limite à publicidade no processo penal, também se encontra abrangida pela noção de intimidade disciplinada na Constituição Federal.

\subsection{A liberdade de expressão - a liberdade de} comunicação ou de informação

\subsubsection{Noções conceituais}

Os pensamentos, ideias, opiniões, crenças, juízos de valor e o conhecimento sobre fatos ou notícias não demandam tutela alguma, seja para assegurá-los, seja para restringi-los, dada a sua dimensão interna, de modo que ganha relevância a questão relativa à sua tutela na hipótese de exteriorização de seus conteúdos.

Embora haja divergência entre os autores que discorreram sobre o tema acerca da classificação das liberdades relacionadas à difusão das idéias e das notícias ${ }^{219}$, faremos, para fins didáticos, adotando a classificação

${ }^{219}$ SERRANO NUNES JÚNIOR, Vidal. O Direito de Informação e a Concorrência de Direitos Fundamentais. In: A proteção Constitucional da Informação e o Direito à Crítica Jornalística. São Paulo: FTD, p. 24-33. O autor classifica as liberdades relacionadas ao tema, distinguindo o direito de opinião, o direito de expressão, o direito de comunicação e o direito de informação. 
de EDILSOM FARIAS ${ }^{220}$, uma única distinção, entre liberdade de expressão e liberdade de comunicação ou de informação ${ }^{221}$, conquanto, por vezes haja intersecção entre as duas categorias - às vezes, por exemplo, é difícil estabelecer-se nítida separação entre informação e opinião.

Por um lado, a liberdade de expressão compreende as liberdades de manifestações de pensamento, de opinião, de juízo de valor, de consciência, de crença, de ideia, artísticas, científicas e culturais. Trata-se de liberdades de natureza eminentemente subjetiva.

Por outro lado, a liberdade de comunicação abrange a liberdade de informação, termo mais utilizado em documentos internacionais ${ }^{222}$, em todas as suas dimensões: o direito de informar, o direito de ser informado (ao qual corresponde um dever de informar), numa perspectiva subjetiva, e o direito à informação, no âmbito da coletividade, visto que o surgimento e a evolução dos meios de comunicação transformaram, nas palavras de JOSÉ AFONSO DA SILVA, a liberdade individual de informar num direito "contaminado de sentido coletivo",223. O conteúdo da liberdade de informação é,

220 FARIAS, Edilsom. Liberdade de Expressão e Comunicação: Teoria e proteção constitucional. São Paulo: RT, 2004, p. 52-55.

221 EDILSOM FARIAS assevera preferir o termo comunicação, que melhor expressa a ideia de transmissão, ao passo que o termo informação é mais adequado a designar um conteúdo possível do processo comunicativo, in FARIAS, Edilson. Liberdade de Expressão... op. cit., p. 52-55.

222 FREITAS NOBRE destaca que a "fixação internacional do conceito e a escolha da palavra 'informação', para designar todos os meios de difusão do pensamento e o direito de informar e de ser informado, permitiram o emprego habitual do termo nas regiões mais distantes do globo", de modo que se percebe que "as pessoas, que tentam fixar uma definição e não a encontram, compreendem, perfeitamente, e aceitam sem discussão o fenômeno e suas consequências", in: NOBRE, Freitas. Comentários à Lei de Imprensa. São Paulo: Saraiva, 1978, p. 08.

223 Afonso DA SIlva, José. Curso de Direito Constitucional Positivo. 28. ed. São Paulo: Malheiros, 2007, p. 260. 
em regra, objetivo, suscetível, pois, de "comprovação da verdade"224. Eis aí um dos aspectos que demonstra a relevância da distinção.

É certo, outrossim, que a liberdade de expressão e a liberdade de informação, esta última analisada apenas sob o aspecto subjetivo, concernente à liberdade do indivíduo de divulgar fatos e notícias de que tem conhecimento, ligam-se à dimensão negativa da liberdade, entendida como nãoimpedimento, não interferência de outros e do próprio Estado na vida privada. Prendem-se à concepção atribuída por CELSO LAFER a BENJAMIN CONSTANT, de liberdade moderna, tutelada nas declarações de direito e no direito positivo desde o século XVIII ${ }^{225}$.

A liberdade de informação possui, ademais, uma dimensão coletiva, que se liga, na nossa interpretação, ao conceito de liberdade antiga, também trabalhado por BENJAMIN CONSTANT, com raízes na democracia ateniense dos séculos V e IV a.C., referindo-se à ideia de distribuição democrática do poder entre os cidadãos, que se opõe ao autoritarismo ${ }^{226}$.

Ora, somente o livre exercício por todos os cidadãos do direito de informar, do direito de ser informado corretamente sobre os fatos (ao qual corresponde um dever de informar) e do direito coletivo à informação podem propiciar as condições para a distribuição democrática do poder, sob a perspectiva dos governados - ex parte populi.

\footnotetext{
${ }^{224}$ FARIAS, Edilsom, op. cit., p. 55.

${ }^{225}$ LAFER, Celso. Ensaios sobre a Liberdade. São Paulo: Editora Perspectiva, 1980, p. 18-21.

${ }^{226}$ Ibidem, p. 12-17.
} 
Temos assim que a dimensão coletiva do direito de informar condiciona, em certa medida, a própria democracia, propiciando aos cidadãos a obtenção de informações imprescindíveis para a sua fundamental participação política, bem assim, a fiscalização do poder, tratando-se de importante "mecanismo de controle, ex parte populi, da conduta dos governantes"

E mesmo a dimensão subjetiva das liberdades de expressão e de informação, propiciando a difusão de novas ideias e opiniões, constitui importante pano de fundo das democracias.

Os aspectos acima destacados bem revelam a fundamental importância da tutela das liberdades de expressão e de informação, na esfera da proteção dos direitos humanos, para a implementação e desenvolvimento das democracias, criando, na visão de NORBERTO BOBBIO, as condições para a possibilidade de paz no plano mundial ${ }^{228}$, a "paz perpétua", no sentido kantiano da expressão.

\subsubsection{A evolução da tutela das liberdades de expressão e} informação no plano internacional

Embora os gregos antigos - atenienses - e posteriormente os Ingleses - o Parlamento, em 1695, não reiterou o Licensing Act, que disciplinava a censura prévia ${ }^{229}$ - já se tivessem preocupado anteriormente com

${ }^{227}$ LAFER, Celso. A Reconstrução... op. cit., p. 243.

${ }^{228}$ BOBBIO, Norberto. A Era... op. cit., p. 21-22.

${ }^{229}$ DONNINI, Oduvaldo, DONNINI, Rogério Ferraz. Imprensa Livre: Dano Moral, Dano à Imagem e sua quantificação à luz do novo Código Civil. São Paulo: Método, 2002, p. 31. 
a liberdade de expressão e de informação, merecem maior destaque a francesa Declaração dos Direitos do Homem e do Cidadão, de 1789, que em seu artigo 11 estabeleceu "la libre communication des pensées et des opinions comme um des droits les plus précieux de l'homme",230 - a livre comunicação dos pensamentos e das opiniões como um dos direitos mais preciosos do homem, também garantida na Constituição Francesa de 1791 - e as declarações americanas - Virginia Bill of Rights (Constituição do Estado da Virgínia), de 1776, que dispunha em seu artigo 12 que "a liberdade de imprensa é um dos grandes baluartes da liberdade e jamais pode ser restringida, senão por um governo despótico", e a Primeira Emenda ao texto original da Constituição norte-americana: "O Congresso não legislará no sentido de estabelecer uma religião, ou proibindo o livre exercício dos cultos; ou cerceando a liberdade de palavra, ou de imprensa, ou o direito do povo se reunir pacificamente e de dirigir ao Governo petições para a reparação de seus agravos" ${ }^{, 231}$.

No plano internacional, a Declaração Universal dos Direitos Humanos, de 1948, estabeleceu em seu artigo XIX:

Toda pessoa tem direito à liberdade de opinião e expressão; este direito inclui a liberdade de, sem interferência, ter opiniões e de procurar receber e transmitir informações e ideias por quaisquer meios e independentemente de fronteiras.

\footnotetext{
${ }^{230}$ DONNINI, Oduvaldo, DONNINI, Rogério Ferraz. Imprensa, op. cit., p. 32.

${ }^{231}$ FARIAS, Edilsom, op. cit. p. 59.
} 
Marcantes, em tal diploma, os aspectos que, no pensamento de $\mathrm{BOBBIO}^{232}$, constituem três das etapas de construção do estado democrático de direito, a saber: a positivação, a generalização e a internacionalização da liberdade em comento.

Ainda no plano internacional cabe mencionar o Pacto Internacional dos Direitos Civis e Políticos de 1966 (ratificado pelo Brasil em 1992), prescrevendo, em seu artigo 19:

1. Ninguém poderá ser molestado pelas suas opiniões. 2. Toda e qualquer pessoa terá direito à liberdade de expressão; esse direito incluirá a liberdade de procurar, receber e difundir informações e ideias de toda a espécie, sem consideração de fronteiras, sob forma escrita ou oral, impressa ou artística, ou por qualquer outro meio a sua escolha. 3. O exercício das liberdades previstas no parágrafo 2 do presente artigo comporta deveres e responsabilidades especiais. Pode, em consequência, ser submetido a certas restrições, as quais, todavia, devem ser expressamente previstas em lei e ser necessárias para: a) garantir o respeito dos direitos ou da reputação de outros; b) proteger a segurança nacional, a ordem, a saúde ou a moral públicas ${ }^{233}$.

\footnotetext{
${ }^{232}$ BOBBIO, Norberto, op. cit., p. 221 e seq.

${ }^{233}$ FARIAS, Edilsom, op. cit. p. 60-61.
} 
As restrições apontadas neste pacto, em virtude de suas peculiaridades, chamam a atenção.

Merece lembrança, no âmbito regional, a Convenção Européia dos Direitos do Homem - Roma, 1950 -, estatuindo em seu artigo 10:

1. Toda pessoa tem direito à liberdade de expressão. Este direito compreende a liberdade de opinião e a liberdade de receber ou comunicar informações ou ideias sem que possa haver ingerência de autoridades públicas e sem consideração de fronteiras. O presente artigo não impede que os Estados submetam as empresas de radiodifusão, cinematográfica ou de televisão a um regime de autorização prévia. 2. O exercício destas liberdades, que contêm deveres e responsabilidades, poderá ser submetido a certas formalidades, condições, restrições ou sanções previstas pela lei, que constituem medidas necessárias em uma sociedade democrática para a segurança nacional, a integridade territorial ou a segurança pública, a defesa da ordem e a prevenção do delito, a proteção da saúde ou da moral, a proteção da reputação ou dos direitos alheios, para impedir a divulgação de informações confidenciais ou para garantir a autoridade e a imparcialidade do poder judicial $^{234}$.

${ }^{234}$ DONNINI, Oduvaldo; DONNINI, Rogério Ferraz, op. cit., p. 33-34. 
Em tal diploma, como se vê, já havia restrições e disciplina sobre prévia autorização para as empresas de radiodifusão, cinematográfica e de televisão.

A Carta Africana dos Direitos do Homem e dos Povos, de 1981, é outro diploma regional que consagra as mesmas liberdades em seu artigo $9^{\circ}$.

Um último sistema regional a destacar-se no presente trabalho consiste na Convenção Americana sobre Direitos Humanos, de 1969, conhecida como Pacto de São José da Costa Rica, ratificada pelo Brasil em 1992.

O artigo 13 da Convenção assim prescreve:

1. Toda pessoa tem direito à liberdade de pensamento e de expressão. Esse direito compreende a liberdade de buscar, receber e difundir informações e ideias de toda natureza, sem consideração de fronteiras, verbalmente ou por escrito, ou em forma impressa ou artística, ou por qualquer outro processo de sua escolha.

2. O exercício do direito previsto no inciso precedente não pode estar sujeito a censura prévia, mas a responsabilidades ulteriores, que devem ser expressamente fixadas pela lei a ser necessária para assegurar: 
a) o respeito aos direitos ou à reputação das demais pessoas; ou

b) a proteção da segurança nacional, da ordem pública, ou da saúde ou da moral públicas.

3. Não se pode restringir o direito de expressão por vias ou meios indiretos, tais como o abuso de controles oficiais ou particulares de papel de imprensa, de freqüências radioelétricas ou de equipamentos e aparelhos usados na difusão de informação, nem por quaisquer outros meios destinados a obstar a comunicação e a circulação de ideias e opiniões.

4. A lei pode submeter os espetáculos públicos a censura prévia, com o objetivo exclusivo de regular o acesso a eles, para proteção moral da infância e da adolescência, sem prejuízo do disposto no inciso $2^{\circ}$.

5. A lei deve proibir toda propaganda a favor da guerra, bem como toda apologia ao ódio nacional, racial ou religioso que constitua incitação à discriminação, à hostilidade, ao crime ou à violência.

O artigo 14 da Convenção disciplina ainda o direito de resposta: 
1. Toda pessoa atingida por informações inexatas ou ofensivas emitidas em seu prejuízo por meios de difusão legalmente regulamentados e que se dirijam ao público em geral, tem direito a fazer, pelo mesmo órgão de difusão, sua retificação ou resposta, nas condições que estabeleça a lei.

2. Em nenhum caso a retificação ou a resposta eximirão das outras responsabilidades legais em que se houver incorrido.

3. Para a efetiva proteção da honra e da reputação, toda publicação ou empresa jornalística, cinematográfica, de rádio ou televisão, deve ter uma pessoa responsável que não seja protegida por imunidades nem goze de foro especial.

8.2.3. A evolução histórica no Brasil da tutela da liberdade de expressão e de informação no plano constitucional

GUIOMARI GARSON DA COSTA GARCIA destaca que a Constituição do Império (1824): "assegurava a liberdade de imprensa, vedando expressamente a censura (art. 179, $\S 5^{\circ}$ ), mas sujeitando o abuso às penas da 
1ei” 235 . Esclarece, contudo, que na prática havia a censura e a imprensa sofria sanções truculentas quando contrárias ao regime vigente.

A primeira Constituição da República "manteve, no particular, o mesmo perfil constitucional agregando, apenas, a vedação do anonimato (art. 72, § 12)"236.

A Constituição de 1934, já sob o governo de Getúlio Vargas, ampliou as restrições ao livre fluxo de informações. O artigo 113, n. 9:

instituiu o direito de resposta e, ao mesmo tempo em vedou o anonimato, previu expressamente a possibilidade de censura prévia aos espetáculos e diversões públicas, bem assim proibiu a propaganda de guerra ou de processo violentos de subversão da ordem política e social.

E a Constituição de 1937:

implantou o mais rigoroso sistema de censura conhecido em nossa história constitucional, o qual, mercê das disposições do Dec. 1949, de 30.12.1939, instituiu a censura prévia também à imprensa estabelecendo,

235 COSTA GARCIA, Guiomari Garson da. Estado Democrático de Direito e Liberdade de Expressão e Informação. Revista de Direito Constitucional e Internacional, ano 11, janeiro-março de 2003 , p. 258 et. seq.

${ }^{236}$ Ibidem, p. 258 et. seq. 
inclusive, a possibilidade da proibição da circulação de periódicos ${ }^{237}$.

A Constituição de 1946, embora refletindo a democratização do país, estendeu a "proibição à propaganda de preconceitos de raça e classe", tentando coibir a "veiculação das idéias marxistas que eram veiculadas, em especial, pelo Partido Comunista brasileiro que, não por acaso, havia sido proscrito pela própria Assembléia nacional constituinte"238.

Foram editados, a partir do golpe de 1964, atos institucionais que suspenderam a vigência de artigos da Constituição de 1946 e de leis então em vigor, cerceando-se de forma significativa a liberdade de expressão, culminando com a Constituição de 1967 (artigo 150, § 8º ) EC 1/69 (artigo $153, \S 8^{\circ}$, e artigo $174, \S 2^{\circ}$ ), que, embora de aparência liberal, pois não previam expressamente a censura, atribuíam à legislação infraconstitucional a competência para estabelecer "condições para a organização e funcionamento" dos veículos de comunicação, para a preservação “do regime democrático e do combate à subversão e à corrupção" ${ }^{, 239}$.

A atual Constituição Federal, promulgada em 1988, com a redemocratização do país, passou a tutelar, de forma bem ampla, as liberdades de expressão e de informação, em todas as suas dimensões.

\footnotetext{
${ }^{237}$ COSTA GARCIA, Guiomari Garson da. Estado Democrático... op. cit., p. 258 et. seq. ${ }^{238}$ Idem.

${ }^{239}$ Idem.
} 
Com efeito:

- o artigo $5^{\circ}$, inciso IV, dispõe sobre a liberdade de manifestação do pensamento, vedando o anonimato;

- o artigo $5^{\circ}$, inciso $\mathrm{V}$, assegura o direito de resposta e o direito à indenização por dano material, moral ou à imagem;

- o artigo $5^{\circ}$, inciso VI, estabelece a inviolabilidade da liberdade de consciência e de crença, assegurando o livre exercício dos cultos religiosos e garantindo, na forma da lei, a proteção aos locais de culto e a suas liturgias;

- o $\operatorname{artigo~} 5^{\circ}$, inciso VII, disciplina a liberdade de crença religiosa, convicção política ou filosófica, também disciplinando a escusa de consciência;

- o artigo $5^{\circ}$, inciso IX, regula a liberdade de expressão da atividade intelectual, artística científica e de comunicação, independente de censura ou licença;

- o artigo $5^{\circ}$, inciso XIV, resguarda a todos o acesso à informação e resguardado o sigilo da fonte, quando necessário ao exercício profissional; 
- o artigo $5^{\circ}$, nos incisos XVI, XVII, XVIII, XIX, XX e XXI, disciplina a liberdade de reunião e de associação, que possuem íntimas ligações com a liberdade de expressão;

- o artigo $5^{\circ}$, inciso XXXIII, regula os direitos individual e coletivo acerca do recebimento de informações dos órgãos públicos, ressalvadas aquelas cujo sigilo seja imprescindível à segurança da sociedade e do Estado, e o inciso LXXII cria inclusive um instrumento processual constitucional para a efetivação de tais direitos, ou seja, o habeas data;

- o artigo $5^{\circ}$, inciso LX, salvaguarda o direito à informação sobre atos processuais, cuja publicidade assegura, ressalvando a possibilidade de sigilo quando a defesa da intimidade ou o interesse social o exigirem;

- o artigo $5^{\circ}$, $\S 2^{\circ}$ e $3^{\circ}$, autoriza a conclusão de que alguns dos textos internacionais supramencionados (o Pacto de 1966 e a Convenção Americana) também fazem parte de nosso ordenamento jurídico.

Outrossim, a dimensão coletiva do direito à informação, já referida no presente trabalho, levou o legislador constitucional a, preocupandose com o aspecto de verdade das informações jornalísticas e de outros valores tutelados pela Constituição Federal, potencialmente ameaçados com o elevado grau de penetração das informações difundidas nos diversos meios de comunicação atualmente existentes, sempre preservando em princípio a liberdade de informação, estabelecer um regime jurídico próprio, com algumas restrições relacionadas ao já enfatizado viés coletivo do direito à informação. 
O regime jurídico a que nos referimos encontra-se disciplinado nos artigos 220 a 224 da Constituição Federal (Capítulo V - DA COMUNICAÇÃO SOCIAL do Título VIII - DA ORDEM SOCIAL). Numa singela síntese, eles estabelecem a liberdade da informação jornalística, estatuindo alguns princípios para a programação de rádio e televisão, restrições a propagandas; regulam a propriedade de empresas jornalísticas; disciplinam as concessões, permissões e autorizações para os serviços de radiodifusão sonora e de sons e imagens etc.

Ensina JOSÉ AFONSO DA SILVA que as:

(...) formas de comunicação regem-se pelos seguintes princípios básicos: (a) observado o disposto na Constituição, não sofrerão qualquer restrição qualquer que seja o processo ou veículo por que se exprimam; (b) nenhuma lei conterá dispositivo que possa constituir embaraço à plena liberdade de informação jornalística; (c) é vedada toda e qualquer forma de censura de natureza política, ideológica e artística; (d) a publicação de veículo impresso de comunicação independe de licença de autoridade; (e) os serviços de radiodifusão sonora e de sons e imagens dependem de autorização, concessão ou permissão do Poder Executivo federal, sob controle sucessivo do Congresso Nacional, a que cabe apreciar o ato, no prazo do art. $64, \S \S 2^{\circ}$ e $4^{\circ}$ (45 dias, que não correm durante o recesso parlamentar); (f) os meios de 
comunicação social não podem, diretamente ou indiretamente, ser objeto de monopólio ${ }^{240}$.

Para sintetizar o sentido da importância da liberdade de informação jornalística, GUIOMARI GARSON DA COSTA GARCIA invoca lição de KARL MARX, em Debates sobre a liberdade de imprensa $e$ comunicação (Düsseldorf, 1841), que, enfatizando os malefícios da censura e os benefícios da liberdade de imprensa, faz as curiosas comparações: "um homem castrado sempre será um mau macho, mesmo se tiver uma voz boa. A natureza continua sendo boa, mesmo se produzir abortos. A essência da imprensa livre é a essência característica, razoável e ética da liberdade. O caráter de uma imprensa censurada é a falta de caráter da não-liberdade; é um monstro civilizado, um aborto perfumado"241 242.

\subsubsection{Os limites à liberdade de informação}

A liberdade de informação nos documentos internacionais e na Constituição Federal, como já se viu, possui limites.

Deve ser inicialmente destacada como limite à liberdade de informação a verdade.

\footnotetext{
${ }^{240}$ AFONSO DA SILVA, José, op. cit., p. 243-44.

${ }^{241}$ COSTA GARCIA, Guiomari Garson da, op. cit.

242 Sobre a evolução da tutela da liberdade de informação no plano infraconstitucional, v. MIRANDA, Darcy Arruda. Comentários à lei de imprensa. Vol. I, São Paulo: Revista dos Tribunais, p. 8-17.
} 
Trata-se, de acordo com PIETRO NUVOLONE, de limite lógico essencial à liberdade de informação, pois o exercício desta, por sua própria natureza, não se confunde com a invenção de fatos imaginários ${ }^{243}$.

Em outras palavras, informar não se confunde com mentir ou divulgar fatos mentirosos.

O interesse social também constitui outro limite à liberdade de informação.

É certo, todavia, que o conceito de interesse social é extremamente vago e genérico ${ }^{244}$.

Não se pode ainda olvidar a já ressaltada dimensão coletiva do direito à informação, ao qual corresponde o direito de informar, condicionante do direito dos indivíduos de fiscalizarem o exercício do poder, de formarem opinião sobre fatos de relevância na comunidade de que fazem parte e de participarem politicamente das decisões tomadas no âmbito de tal comunidade.

A referida dimensão coletiva dificulta o estabelecimento de limite à liberdade de informação fundado em genérica apreciação sobre a aparente ausência de interesse social da informação.

\footnotetext{
${ }^{243}$ NUVOLONE, Pietro. Il Dirito Penale della Stampa. Padova: Cedam, 1971, p. 54. ${ }^{244}$ Idem.
} 
Embora correta a concepção de que a informação realmente deva versar sobre fatos de interesse social, parece-nos mais adequada a ideia de que, em virtude da vital importância do direito de informar, os limites a serem estabelecidos a esta liberdade devem restringir-se às hipóteses de conflito entre o direito de informar e outros direitos fundamentais, a serem dirimidas por meio de ponderação a ser realizada no caso concreto $^{245}$ com a aplicação do postulado da proporcionalidade.

O direito de informar encontra, assim, limites nos já analisados direitos à intimidade, à privacidade, à imagem e à honra dos indivíduos, cuja proteção se estabelece nos termos da Teoria dos Três Graus, analisada no início deste capítulo.

Outros valores, especialmente no âmbito da crônica policial e judicial, também deverão ser considerados como limites ao exercício do direito de informar.

Referimo-nos a princípios e garantias processuais que podem vir a ser violentamente atingidos pelo exercício ilimitado do direito de informar, que pode implicar sérias restrições ao princípio do estado de inocência, ao contraditório, à ampla defesa e à imparcialidade do julgador, comprometendo até mesmo a ideia de far trial ou de julgamento justo.

Impõe-se então a análise sobre o modo pelo qual se desenvolve o conflito entre o direito de informar, os direitos de índole pessoal,

${ }^{245}$ NUVOLONE, Pietro. Il Dirito..., p. 56. 
os princípios e garantias processuais e a publicidade nas duas fases da persecução penal.

\subsection{O confronto entre a intimidade e a liberdade de} informação/comunicação, e a sua relação com a garantia da publicidade

\subsubsection{A fase investigatória}

As infrações penais representam violações aos mais importantes valores contemplados no ordenamento jurídico, atingindo, em regra, não apenas a pessoa do ofendido, mas, sobretudo, a coletividade e a ordem jurídica estabelecida. Os ilícitos penais causam desestabilização social.

É inequívoco, portanto, que existe, sim, interesse público de informação sobre a ocorrência do fato ilícito e sua autoria.

PIETRO NUVOLONE ressalta que a publicidade da infração penal e de seu autor na fase policial propicia, de um lado, que pessoas com algum conhecimento sobre o fato prestem auxílio na sua elucidação e, de outro, que se extraiam diretrizes sobre os comportamentos adequados a serem observadas nas relações sociais ${ }^{246}$.

246 Assevera PIETRO NUVOLONE: "Il delito suscita, per definizione, um allarme sociale, inquanto lede um interesse pubblico, comune a tutti. Tutti, pertanto, hanno Il diritto di conoscere $i$ fatti commessi in violazione della legge penale: sai perché, dalla conoscenza sorge La possibilita dell'esercizio Del diritto di denuncia, sai perché, dalla conoscenza dei delitti e dei loro autori, ognuno há La possibilita dell'esercizio Del diritto di denuncia, sia perché, dalla conoscenza dei delitti e dei loro autori, ognuno há La possibilita de trarre norme di orientamento 
DARCY ARRUDA MIRANDA assevera ser:

(..) direito da imprensa denunciar os fatos criminosos antes mesmo que estes sejam conhecidos da polícia, uma vez que ela exerce, indiscutivelmente o papel de esculca da coletividade, e do seu mirante pode apreciara panoramas ainda inobservados pela polícia, dando ensejo a esta de apurar a realidade dos fatos ${ }^{247}$.

NUVOLONE também entende que o direito de informar, no âmbito na persecução penal, não se restringe à fase do processo, abrangendo a possibilidade de serem veiculadas notícias sobre informações obtidas por meio da polícia ou de outra fonte direta ${ }^{248}$.

É fácil constatar, todavia, a ocorrência de alguns abusos atinentes à cobertura jornalística criminal, quer os relacionados a distorções propiciadas pelos jornalistas incumbidos de conferir ao público informações sobre os casos, quer em virtude da aplicação inadequada da publicidade pelos próprios agentes incumbidos da persecução penal (policiais, escrivães de polícia, Delegados de Polícia e membros do Ministério Público).

Nei rapporti della vita sociale. È ovvio, peraltro, Che Il cronista non solo dovrá attenersi ai dettami della verità, ma anche evitare di incidere sull'onorabilità privaata quando La notizia pervenutagli non abbia Il carattere della certezza; e soprattutto mantenere um rigoroso riserbo sui nome delle persone, Che, pur essendo collegate ai fatti criminosi, ma non essenco autrici, potrebbero ricevere danno da um'incauta pubblicità fatta attorno alle loro vicende." In NUVOLONE, Pietro. Il Diritto Penale... op. cit., p. 60.

${ }^{247}$ MIRANDA, Darcy Arruda. Comentários à lei... op. cit., vol. p. 550.

${ }^{248}$ NUVOLONE, Pietro. Il Diritto Penale... op. cit., p. 63. 
A doutrina brasileira costuma sempre referir alguns casos célebres de abuso ${ }^{249}$, mas nos parece mais correta a noção de que os abusos não se ligam apenas aos casos célebres, podendo ser vislumbrados, lamentavelmente, quase diariamente na crônica policial.

ANA LÚCIA MENEZES VIEIRA bem descreve os abusos relacionados ao jornalismo policial:

(...) a prisão em flagrante do suspeito do crime, a condução do detido à delegacia, a sua apresentação à autoridade policial são alvos da mídia pela maneira como tudo acontece: a viatura com a sirene ligada, os policiais armados conduzindo o preso algemado, cabisbaixo, acuado, procurando furtar-se ao bombardeio das incisivas perguntas dos repórteres sobre o delito e as circunstâncias, tudo sob as luzes das câmeras. Paulo foram acusados de abusar sexualmente de crianças, tendo seu estabelecimento fechado, suas vidas devassadas e humilhadas, em razão do clamor da imprensa, descobrindo-se posteriormente que o 'julgamento' feito pela mídia correspondia, na realidade, às conclusões de um Delegado de Polícia posteriormente não confirmadas; ao caso do "Bar Bodega", no qual a polícia apresentou à mídia nove jovens como responsáveis por um duplo homicídio num bar situado em bairro nobre de São Paulo, mas tais jovens, consoante posteriormente se demonstrou, não possuíam envolvimento com os delitos. In LEÃO DE SOUZA, Diego Fajardo Maranha, LEITE, Rosimeire Ventura. O sigilo no processo criminal e o interesse público à informação. In Sigilo no Processo Penal - Eficiência e Garantismo. Vários autores, sob a coordenação de Antonio Scarance Fernandes, José Raul Gavião de Almeida e Maurício Zanoide de Moraes. São Paulo: RT, 2008, p. 212-213. 
A cena criada e desenvolvida pelos meios de comunicação, no palco do espetáculo do crime, é transformada em notícia divulgada não como informação, mas como condenação definitiva. O suspeito ou indiciado é transformado em réu, as circunstâncias ainda não apuradas do crime são as provas cabais da materialidade, e a matéria jornalística é veiculada como decreto de morte moral do indivíduo submetido, ainda, às investigações. E estas só se iniciaram ${ }^{250}$.

Os aludidos abusos, não há dúvidas, representam sérios riscos a direitos fundamentais dos suspeitos da prática de ilícitos penais.

Embora se diga que os abusos ora em comento atinjam os direitos à intimidade, à privacidade, à imagem e à honra dos supostos autores de crimes $^{251}$, não vislumbramos, em princípio, o comprometimento de tais direitos de índole pessoal em virtude das mencionadas práticas que fazem parte do cotidiano da crônica policial.

É que, de acordo com as premissas postas no presente capítulo pertinentes às noções estabelecidas para os direitos de índole pessoal, a prática de uma infração penal, que atinge a coletividade como um todo, não pode ser tida por aspecto que se refira à representação da personalidade do

\footnotetext{
${ }^{250}$ MENEZES VIEIRA, Ana Lúcia. Processo Penal... op. cit., p. 192.

${ }^{251}$ Nesse sentido, MENEZES VIEIRA, Ana Lúcia. Processo Penal... op. cit., p. 192; LEÃO DE SOUZA, Diego Fajardo Maranha, LEITE, Rosimeire Ventura. O sigilo no processo... op. cit. criminal e o interesse público à informação. In Sigilo no Processo Penal - Eficiência e Garantismo. Vários autores, sob a coordenação de Antonio Scarance Fernandes, José Raul Gavião de Almeida e Maurício Zanoide de Moraes. São Paulo: RT, 2008, p. 210.
} 
indivíduo na sua esfera de intimidade/privacidade inviolável, pois certo é que o interesse público relativo ao exercício do direito de informação, feita a ponderação, certamente prepondera sobre os mencionados direitos de índole pessoal.

Não pode o indivíduo pretender o segredo, que é o principal objetivo da tutela dos direitos de índole pessoal, de atos que representam lesão aos principais valores de uma comunidade.

É inequívoco, contudo, que os abusos relativos à cobertura jornalística criminal atingem de forma violenta os direitos ao contraditório, à ampla defesa, o princípio do estado de inocência e, em última análise, o resultado justo do processo.

A exposição do indivíduo que acaba de ser detido, algemado, por intermédio dos meios de comunicação de massa, aos olhos do grande público, por vezes até mesmo acompanhada de pronunciamento contendo juízo de valor sobre o fato que será objeto de uma investigação e de um processo criminal e sobre a culpabilidade do envolvido, realmente pode restringir significativamente o exercício de defesa num futuro procedimento penal.

A apresentação do indivíduo em tais condições também traduz a conotação de que se trata de pessoa "culpada" pela prática da infração penal, subvertendo o princípio do estado de inocência previsto no artigo $5^{\circ}$, inciso LVII, da Constituição Federal, segundo o qual: "ninguém será considerado culpado até o trânsito em julgado da sentença penal condenatória”. 
$\mathrm{O}$ abuso em questão pode, até mesmo, comprometer o trabalho de apuração da infração penal pela autoridade policial e, por consequência, o do Ministério Público, em regra destinatário da investigação policial.

Não podem ainda ser olvidadas as hipóteses em que a mídia, além de expor o indivíduo investigado, proporciona verdadeira apuração paralela do fato, com a oitiva de vítimas, testemunhas, autoridades envolvidas na apuração, membros do Ministério Público, advogados, juízes, promovendo um "julgamento paralelo" 252 , o que pode comprometer significativamente a atuação das partes no processo, o direito à ampla defesa, o princípio do estado de inocência e, notadamente nos casos a serem submetidos a julgamento perante o Tribunal do Júri, a imparcialidade do julgador, inviabilizando assim o far trial ou o processo justo e, consequentemente, a tomada de decisão justa.

JORGE DE FIGUEIREDO DIAS assevera que a publicidade propiciada pelos meios de informação deve ser ampla, mas com um limite intransponível: não pode causar risco ao direito de defesa, nem à pretensão punitiva do Estado, inviabilizando um far trial, julgamento justo ${ }^{253}$.

Como então solucionar o grave conflito entre o direito de informar e as apontadas garantias processuais?

Pensamos que a questão posta possui complexa solução.

252 COBO DEL ROSAL, Manuel.Lo inverossímil de los juicios paralelos. In Quisicosas de los delitos y delas penas. Madrid: CESEJ, 2005, p. 341.

${ }^{253}$ FIGUEIREDO DIAS, Jorge de. Direito Processual... op. cit., p. 226. 
De um lado, no que se refere aos agentes públicos envolvidos na persecução penal, temos que, desde o instante em que o suspeito/averiguado encontra-se sob a custódia ou investigação de um agente do Estado (policial, escrivão de polícia, Delegado de Polícia, membro do Ministério Público etc.), assume este, ainda que parcialmente, a responsabilidade pela observância dos direitos fundamentais do investigado potencialmente envolvidos na situação.

Incumbe-lhe, assim, zelar para que o direito de informar não se sobreponha de forma absoluta às garantias processuais do investigado, aplicando, para tanto, o método da proporcionalidade exposto no capítulo anterior.

O policial responsável pela prisão em flagrante do réu deve, dessarte, impedir que sejam feitas imagens e fotografias do indivíduo detido com a utilização de algemas e em circunstâncias aptas a transmitiram a noção de que é a pessoa "culpada" pela infração penal, bem como que sejam realizadas "entrevistas" com a pessoa que acaba de ser detida. Pode, todavia, fornecer informações objetivas aos jornalistas acerca das circunstâncias em que foi o averiguado detido.

As autoridades incumbidas das investigações também devem impedir o acesso irrestrito dos meios de comunicação às dependências da repartição pública na qual se formalizam os atos investigatórios, com o registro de imagens e entrevistas do averiguado em condições que comprometam irremediavelmente os já mencionados direitos fundamentais relacionados à persecução, podendo, contudo, fornecer aos jornalistas informações objetivas sobre os atos formalizados, aos quais os meios de comunicação também poderão ter acesso. 
Cabe neste ponto salientar que, além de se fundamentarem nos dispositivos constitucionais que disciplinam o devido processo legal, cujas garantias, como já se viu no capítulo 5, também se projetam, ainda que parcialmente, nos procedimentos de investigação, e no princípio do estado de inocência, as limitações sugeridas encontram amparo nos tratados internacionais que autorizam a limitação da publicidade no interesse da justiça, merecendo especial destaque o Pacto Internacional dos Direitos Civis e Políticos (art. 14-1) e a Convenção Americana sobre Direitos Humanos (art. $8^{\circ}$ ), e o artigo 20 do Código de Processo Penal, que propicia o sigilo no inquérito para a elucidação do fato e no interesse da sociedade.

As apontadas restrições justificam-se, por se mostrarem adequadas à promoção da finalidade de preservar as garantias envolvidas na persecução; necessárias para que sejam atingidos os aludidos fins, pois, nos moldes propostos, promovem a finalidade visada com o menor sacrifício possível do direito de informar; e proporcionais em sentido estrito, porque, ante a concreta possibilidade de absoluto comprometimento das garantias processuais, a preservação destas possui um "peso" maior do que o exercício irrestrito da liberdade de informar.

A solução proposta, de limitação apenas parcial, relativa aos aspectos de potencial comprometimento dos valores mencionados, também leva em linha de conta a possibilidade de terem os meios de comunicação acesso direto às fontes de prova e a outras informações relativas à infração penal apurada, de modo que o absoluto sigilo das investigações não eliminaria os efeitos deletérios dos já referidos "julgamentos paralelos". 
Conferir-se, portanto, acesso dos meios de comunicação aos elementos informativos constantes da investigação representa uma forma de mitigar os efeitos deletérios de tais "julgamentos paralelos".

Em outras palavras, a publicidade constitui o melhor remédio contra os referidos "julgamentos paralelos" e o comprometimento de direitos fundamentais do investigado que eles representam.

De outro lado, a solução da questão também passa pelo exercício responsável do direito de informar pelos meios de comunicação, cujos abusos devem ser reprimidos forma contundente pelos abusos.

O referido aspecto não se relaciona, entretanto, diretamente com o conflito entre a publicidade e as suas limitações, daí porque não será objeto de análise minuciosa, embora lamentemos, neste ponto, a ausência de legislação apta a coibir os abusos apontados.

\subsubsection{O processo penal}

A análise da evolução histórica da publicidade realizada no capítulo 1 evidencia que, na fase processual, a garantia representa importante conquista do pensamento iluminista, a partir da qual se transmudou em verdadeiro dogma nos ordenamentos jurídicos de índole democrática.

Estabeleceu-se, assim, de acordo com as observações já realizadas no capítulo 6 do presente trabalho, que, se na fase investigatória a publicidade pode sofrer maiores restrições a fim de conferir efetividade ao seu 
escopo de apuração da infração penal e de sua respectiva autoria - mas sempre se tendo presente a noção de proporcionalidade para que se opere a limitação -, na fase do processo a publicidade deve imperar, sofrendo restrições apenas nas hipóteses previstas no texto constitucional e nos termos da lei, já apreciadas no aludido capítulo.

Duas questões remanescem, porém, no que diz respeito à análise do conflito entre a publicidade, o direito de informar e a intimidade no processo penal.

A primeira delas é atinente à limitação estabelecida pelo artigo 201, $\S 6^{\circ}$, do Código de Processo Penal, com a redação trazida pela Lei n. $11.690 / 08$.

A referida norma, inserida em conjunto de preceitos reveladores da preocupação do legislador com a situação do ofendido na persecução penal, o que mereceu aplauso da doutrina, assim estabelece:

$\S 6^{\circ} \mathrm{O}$ juiz tomará as providências necessárias à preservação da intimidade, vida privada, honra e imagem do ofendido, podendo, inclusive, determinar o segredo de justiça em relação aos dados, depoimentos e outras informações constantes dos autos a seu respeito para evitar sua exposição aos meios de comunicação.

É manifesta, na norma, a preocupação com a tutela de direitos de índole pessoal do ofendido, relevando, contudo, observar que a sua existência não elimina, por si, a necessidade de ponderação entre os 
mencionados direitos e o direito de informar, tendo como pano de fundo a publicidade do processo.

Uma observação inicial a ser feita é a de que o juiz somente poderá adotara as providências previstas no dispositivo após a solicitação do ofendido, pois se, como já se analisou neste capítulo, os direitos de índole pessoal dizem respeito a aspectos da vida do indivíduo em relação aos quais ele pretende segredo, apenas o próprio interessado poderá declinar sobre quais aspectos de sua vida deseja o sigilo.

A solicitação do ofendido não é, todavia, o único aspecto a ser considerado para que magistrado adote uma das medidas dispostas na lei, de maneira que o julgador deverá fazer a análise de proporcionalidade (adequação, necessidade e proporcionalidade em sentido estrito) da restrição à publicidade e ao direito de informar.

Assim é que a imposição das medidas especificadas no dispositivo legal em comento revelar-se-ão adequadas, necessárias e proporcionais em sentido estrito, à medida que os fatos objeto de discussão no processo implicarem a revelação de aspectos que se refiram à esfera da intimidade/privacidade do ofendido passível de proteção ou que representem infâmias mendazes contra o ofendido, hipóteses em que a proteção dos direitos de índole pessoal do ofendido deverá preponderar sobre a publicidade e o direito de informar.

A proporcionalidade das medidas revela-se de forma clara, por exemplo, nos processos que versam sobre crimes contra a liberdade sexual da vítima. 
Fora de tais hipóteses, todavia, a publicidade do processo e o direito de informar prevalecerão sobre a tutela da intimidade.

A segunda questão que se põe, no que se refere à possibilidade de limitação da publicidade e do direito de informar, no âmbito do estudo proposto no presente capítulo, concerne à possibilidade de realizar-se a captação de sons e imagens de julgamentos, e a veiculação destes, em tempo real ou por reprodução, pelos meios de comunicação.

Convém lembrar que, quando não dispunham os meios de comunicação de tecnologias capazes de difundir diretamente os atos da persecução penal, a referida questão não se mostrava relevante, mas o avanço das tecnologias, seja com o desenvolvimento de equipamentos capazes de difundir com precisão imagens e sons em tempo real, seja com a massificação dos meios de comunicação por meio do rádio, da televisão e atualmente da internet, conferiu grande importância à discussão em torno da possibilidade de limitar-se a publicidade nos julgamentos, sobretudo para a preservação da intimidade das pessoas envolvidas no ato.

A questão enfocada é extremamente polêmica, ensejando a adoção de soluções bem distintas no direito comparado.

$\mathrm{Na}$ Inglaterra e no País de Gales, o artigo 41 da Criminal Justice Act, de 1925, incriminou a tomada de fotografias na corte, e a jurisprudência firmou posicionamento no sentido de que a vedação estende-se a qualquer tipo de filmagem realizada em julgamento realizado por jurados. A Contempt of Court Act, de 1981, dirigindo-se aos meios de comunicação, autoriza que lhe sejam impostas sérias sanções, abrangendo a possibilidade de sua interdição, na hipótese de divulgação de dados não permitidos do processo, 
fazendo-se o referido controle a priori, ou seja, até mesmo antes de veiculada a publicação ${ }^{254}$.

$\mathrm{Na}$ França, embora a publicidade seja um princípio geral consagrado na lei, as gravações e filmagens apenas são permitidas para registro histórico, pois a sua divulgação é expressamente proibida na lei, a fim de evitar os excessos dos periodistas que poderiam afetar a espontaneidade e a serenidade dos debates ${ }^{255}$.

$\mathrm{Na}$ Alemanha, a publicidade mediata encontra-se "garantida" na lei ( $\$ 169$ Gerichtsverfassungsgesetz) para os informes orais ou escritos, sendo expressamente proibidas as filmagens e gravações com a finalidade de divulgação ao público de seu conteúdo, tendo o Tribunal Constitucional, em 1993, regulamentado as limitações, ampliando um pouco a possibilidade de difusão de imagens e sons dos julgamentos, para autorizá-las em poucas hipóteses, até o ingresso das partes no recinto do julgamento e, sem a utilização de refletores, por ocasião da leitura da parte dispositiva da sentença ${ }^{256}$.

$\mathrm{Na}$ Espanha, diversamente, à falta de norma expressa disciplinando a questão, o Tribunal Constitucional, interpretando a Constituição Espanhola, decidiu, por meio de três importantes sentenças, que a regra geral da publicidade também se estende aos meios de comunicação, o que viabiliza a divulgação de imagens e sons de julgamento, mas ressalvou que na

\footnotetext{
${ }^{254}$ ANITUA, Gabriel Ignacio. El princípio de publicidad... op. cit., p. 91.

${ }^{255}$ Ibidem, p. 92.

${ }^{256}$ Ibidem, p. 92-93.
} 
hipótese de serem atingidos, no caso concreto, outros direitos fundamentais (direitos de índole pessoal e direitos relacionados ao interesse da justiça com o objetivo de evitarem-se os “julgamentos paralelos”), a publicidade midiática, mediante ponderação, poderá ser restringida ${ }^{257}$.

$\mathrm{Na}$ Itália, ao contrário do que ocorre na Espanha, a transmissão dos debates por intermédio do rádio não decorre necessariamente da publicidade reconhecida no ordenamento jurídico italiano ${ }^{258}$, mas, nos termos do artigo 147 do Código de Processo Penal, demanda autorização do juiz, desde que haja consentimento das partes, que pode ser dispensado na hipótese de existir interesse social particularmente relevante ao conhecimento do debate. A captação da imagem das pessoas que estejam presentes, a exemplo de partes, intérpretes, peritos, depende do consentimento delas ou de que não exista proibição legal ${ }^{259}$.

Em Portugal, o registro e a divulgação de imagens de atos processuais, notadamente de audiências, exigem autorização judicial, preservando-se a imagem de quem se opuser à sua difusão ${ }^{260}$.

Nos Estados Unidos, não havia, no início do século passado, restrições ao registro e divulgação de imagens e sons de julgamentos, mas

\footnotetext{
257 GONZÁLEZ GARCÍA, Jesús María. Entre el derecho de defensa y el derecho a La información: viejas e nuevas cuestiones sobre La publicidad de lãs actuaciones Del proceso penal. In Revista Del Poder Judicial, n. 80, cuarto trimestre 2005, p. 100-103.

${ }^{258}$ Ibidem, p. 104-105.

259 LEÃO DE SOUZA, Diego Fajardo Maranha, LEITE, Rosimeire Ventura. O sigilo no processo criminal... op. cit., p. 230 .

${ }^{260}$ LEÃO DE SOUZA, Diego Fajardo Maranha, LEITE, Rosimeire Ventura. O sigilo no processo criminal... op. cit., p. 231.
} 
alguns exageros da mídia ${ }^{261}$ fizeram com que normas éticas da American Bar Association proibissem as fotografias e transmissões via rádio e televisão dos julgamentos. A Suprema Corte, em decisão proferida em 1965 no caso Estes vs. Texas, anulou o julgamento no qual o juiz autorizou a presença da mídia televisiva, mas, posteriormente, modificou o seu posicionamento, deliberando, no caso Chandler vs. Florida em 1981, que a presença dos meios de comunicação nos julgamentos não implica, por si, irregularidade, podendo os estados permitir o emprego de meios eletrônicos e fotográficos para a cobertura jornalística de um julgamento, desde que adotadas as providências necessárias para que se evitasse a violação de garantias processuais. Atualmente, 47 dos 50 estados autorizam, em alguma instância e por meio de regras específicas, as filmagens dos julgamentos. O sistema federal, contudo, não as autoriza. A questão ainda vem sendo intensamente discutida na doutrina, tendo despertado grande interesse nos famosos casos de O. J. Simpson, Susan Smith, Manuel Noriega, Oliver North e Rodney King ${ }^{262}$. No caso California vs. Simpson, em 3 de outubro de 1995, cento e cinquenta milhões de americanos viram e ouviram ao vivo a decisão proferida, tendo os canais de televisão transmitido mais de 2.000 horas do julgamento ao vivo, apensa nos canais Court TV, CNN e E! Entertainmente Network. ${ }^{263}$.

Como se vê, a questão é tratada de formas muito distintas nos diferentes ordenamentos jurídicos.

\footnotetext{
${ }^{261}$ GABRIEL IGNACIO ANITUA assevera que no caso "Scopes", durante a cobertura televisiva, o juiz RAULSTON gabava-se de que o som de seu martelo seria escutado em todo mundo, e o diretor de câmeras indicava ao advogado que se aproximassem do juiz ou que movesse sua cabeça para o melhor registro da imagem. ANITUA, Gabriel Ignacio. El princípio de publicidad... op. cit., p. 88 .

${ }^{262}$ ANITUA, Gabriel Ignacio. El princípio de publicidad... op. cit., p. 88-91.

${ }^{263}$ Ibidem, p. 102.
} 
No Brasil, não há qualquer norma regulamentando a possibilidade de transmissão via rádio ou televisão de sons e imagens de julgamentos.

A possibilidade de transmissão pela televisão de um julgamento foi discutida no rumoroso caso Suzane Louise Von Richthofen, no qual o Tribunal de Justiça do Estado de São Paulo não autorizou o ingresso no local de pessoas portando aparelhos de filmagem ou gravação, fundamentando a sua decisão na possibilidade de violação do direito à intimidade dos envolvidos no julgamento e na necessidade de preservar a atuação dos jurados. No julgado, argumentou-se ainda que a publicidade do processo consiste na garantia de que os atos nele praticados são feitos com lisura, daí se impondo a permanência das portas abertas de forma a propiciar que qualquer pessoa possa ingressar e assistir o julgamento, mas não se confunde a possibilidade de que todo a país possa assistir a um julgamento, inclusive com a possibilidade de retransmissão de trechos das filmagens para a imprensa internacional ${ }^{264}$.

A doutrina também apresenta objeções à possibilidade de serem os julgamentos transmitidos pelos meios de comunicação de massa.

ADA PELLEGRINI GRINOVER adverte que:

(...) toda precaução há de ser tomada contra a exasperação do princípio da publicidade. Os modernos canais de comunicação de massa podem representar um perigo tão

264 TJSP, 5a Câmara da Seção Criminal, HC 972.803.3/0-00, Acórdão registrado sob o n. 01036668, relatado pelo Desembargador José Damião Pinheiro Machado Cogan. 
grande como o próprio segredo. Assim, as audiências televisionadas têm provocado em vários países profundas manifestações de protesto; não só os juízes são perturbados por uma curiosidade malsã, como as próprias partes e as testemunhas se vêem submetidos a excessos de publicidade que infringem seu direito à intimidade, além de conduzir a distorção do próprio funcionamento da justiça, através de pressões impostas ao juiz, às partes, às testemunhas e demais figurantes do drama judicial. Publicidade, como garantia política (cuja finalidade é o controle da opinião pública no serviço da justiça), não pode ser confundida com o escândalo e com o desrespeito à dignidade humana ${ }^{265}$.

Outros autores, exteriorizando idênticas preocupações com o tema, estabelecem a necessidade de regulamentação da matéria no ordenamento jurídico brasileiro, entendendo como imprescindível a anuência da defesa e do acusado para que o julgamento seja televisionado ${ }^{266}$.

ANA LÚCIA MENEZES VIEIRA sustenta que:

(...) os meios tecnológicos de captação e informação das notícias, mais propriamente a televisão, se por um lado são instrumentos eficazes para trazer o desenvolvimento do processo a conhecimento público, por outro são suscetíveis

${ }^{265}$ GRINOVER, Ada Pellegrini. Os Princípios Constitucionais... op. cit., p. 134.

${ }^{266}$ LEÃO DE SOUZA, Diego Fajardo Maranha, LEITE, Rosimeire Ventura. O sigilo no processo criminal... op. cit., p. 233. 
de influenciar os jurados, as partes, os peritos, as testemunhas, bem como o próprio juiz que vai aplicar a pena. A simples presença dos operadores das câmeras televisivas e as expressões dos depoentes podem atrapalhar o regular desenvolvimento da audiência e alterar os equilíbrios emotivos das pessoas envolvidas no processo e, por conseqüência, o resultado do julgamento ${ }^{267}$.

Uma análise mais abrangente da questão posta demanda a retomada de alguns conceitos trabalhados no capítulo 1 desta dissertação, relativos à finalidade do processo e da publicidade.

JORGE DE FIGUEIREDO DIAS assevera que o Estado de Direito Social "não surge como poder ordenador da proteção do arbítrio individual, mas como propulsionador de formas de vida comunitária que assegurem a livre realização da personalidade ética de cada $\mathrm{um}^{268}$. O processo penal desempenha então uma função comunitária. Não se trata mais de mero "aparelho da força estadual ou simples proteção do indivíduo face àquela força, mas, sim, primordialmente assunto da comunidade jurídica", em nome e no interesse da qual se tem de esclarecer, perseguir e punir o crime e o criminoso $^{269}$. A estrutura processual penal não pode aniquilar a liberdade

\footnotetext{
${ }^{267}$ MENEZeS VIEIRA, Ana Lúcia. Processo..., op. cit., p. 235.

${ }^{268}$ FIGUEIREDO DIAS, Jorge de. Direito Processual... op. cit., p. 68-69.

${ }^{269}$ Idem.
} 
individual, nem renunciar às condições indispensáveis para realizar uma função da comunidade ${ }^{270}$.

Tendo em vista a função comunitária desempenhada pelo processo penal, o referido doutrinador afirma que "bem se compreende a sua publicidade como forma óptima de dissipar quaisquer desconfianças que se possam suscitar sobre a independência e a imparcialidade com que é exercida a justiça penal e são tomadas as decisões" ${ }^{271}$, de modo que tanto "o interesse da comunidade (enquanto tal e consubstanciada no tribunal) como o interesse do próprio argüido convergem, pois, no sentido de ser dada publicidade à audiência; esta constitui para todos uma verdadeira garantia" ${ }^{272}$. O autor aduz ainda que a publicidade possui uma vantagem sociológica, qual seja, a de "fomentar e aguçar o sentimento jurídico dos membros da comunidade" 273 , estabelecendo que deve ela ser ampla, mas com um limite intransponível: não pode causar risco ao direito de defesa, nem à pretensão punitiva do Estado, inviabilizando um fair trial, julgamento justo ${ }^{274}$.

GABRIEL IGNACIO ANITUA afirma, nessa linha, que, além dos aspectos de garantia endoprocessual e de garantia política do acusado, a publicidade propicia aos cidadãos o controle sobre a tarefa do Estado de administrar a justiça, conferindo legitimidade aos órgãos incumbidos de tal tarefa e aumentando a confiança do público em seus juízes, e constitui o instrumento mais idôneo para a produção do efeito de prevenção geral atribuído

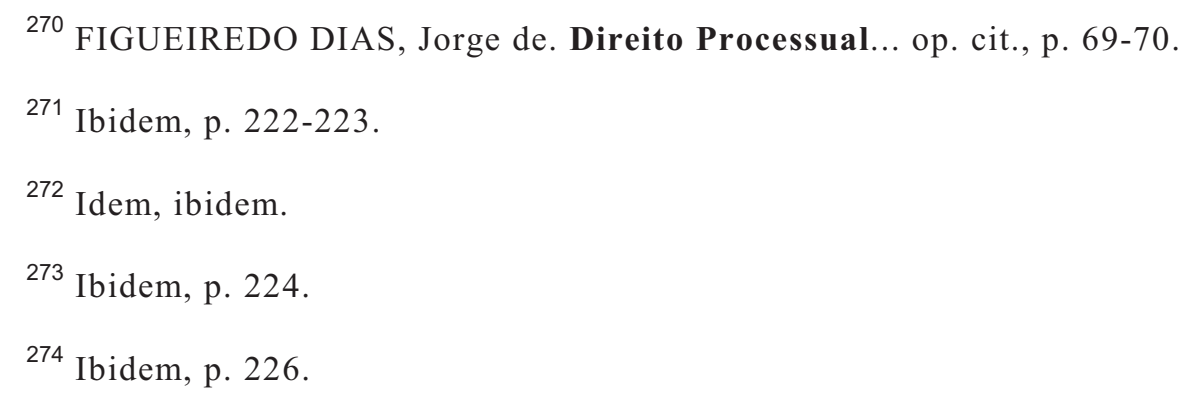


à pena, confirmando e impondo valores morais à generalidade dos indivíduos ${ }^{275}$.

O aludido autor sustenta, portanto, que os tribunais e os processos penais não são assuntos exclusivamente privados, notadamente porque a infração penal representa uma agressão à ordem pública, mas questões de interesse social ${ }^{276}$.

É certo, outrossim, que, nas sociedades contemporâneas, os cidadãos não presenciam os atos públicos para informarem-se sobre eles, mas, em razão das grandes concentrações urbanas, da especialização do trabalho, dos avanços tecnológicos e de outras variáveis, são os meios de comunicação de massa, especialmente o rádio, a televisão e a internet, que estabelecem a publicidade dos fatos de interesse público ${ }^{277}$.

Estabelecida a ideia de que existe um interesse social na apuração dos ilícitos penais, é de se concluir que as finalidades atinentes à publicidade processual apenas se realizarão nas sociedades contemporâneas com a concorrência dos meios de comunicação de massa ${ }^{278}$.

\footnotetext{
275 ANITUA, Gabriel Ignacio. El princípio de publicidad... op. cit., p. 79-82.

${ }^{276}$ Ibidem, p. 82-83.

277 Ibidem, p. 96-97.

278 LANCESTREMERE, Javier. Publicidad efectiva para La construcción de valores sociales. In Revista de derecho penal y procesal penal, n. 03, Buenos Aires: 2004, p. 630-631. No mesmo sentido, ANITUA, Gabriel Ignacio. El princípio de publicidad... op. cit., p. 96-97.
} 
A possibilidade de serem difundidas por intermédio dos meios de comunicação de massa os sons e as imagens dos julgamentos não pode, portanto, ser afastada de plano, sob pena de restrição quase absoluta às finalidades da publicidade.

Os direitos de índole pessoal do acusado não podem, ademais, representar óbice intransponível à possibilidade de atuação dos meios de comunicação de massa no âmbito do processo.

A uma, porque, como já se argumentou neste capítulo, a prática de uma infração penal, ainda que em tese considerada, não constitui ato que se insira na esfera de intimidade do réu, ao menos na esfera de intimidade passível de proteção constitucional, de modo que a tutela de direitos de índole pessoal também não pode constituir óbice intransponível à apuração de uma conduta criminosa.

O processo penal instaurado para a apuração de uma conduta criminosa não se refere, desse modo, a aspectos da intimidade do acusado, não se podendo ainda cogitar em tutela da honra, por não constituir a persecução penal, por si só, numa mentira infamante contra o réu. Também não há cogitarse de tutela da imagem do acusado, pois que o julgamento é público, de modo que a participação do réu no ato dá-se na esfera do público.

A duas, em razão do já salientado interesse social da publicidade, que, em face dos valores de índole pessoal do acusado, revela a adequação e a necessidade da atuação dos meios de comunicação de massa, visto que nas sociedades contemporâneas esta é a única forma que se mostra apta a atingir as finalidades da publicidade, e a proporcionalidade em sentido estrito do meio, visto que o "peso" da realização dos interesses compreendidos 
pela publicidade é, no caso, maior do que os relativos à tutela dos interesses de índole pessoal do réu.

A tutela constitucional da intimidade não constitui, assim, óbice intransponível à captação e divulgação de sons e imagens de julgamentos pelos meios de comunicação de massa, excetuada a situação disciplinada no artigo 201, $\S 6^{\circ}$, do Código de Processo Penal, que, como já se analisou, não prescinde da ponderação, de modo que, na hipótese de entender o juiz proporcional a restrição à liberdade de informação em prol do interesse de preservar a intimidade do ofendido, deverá proibir a captação de sons e imagens relativas ao ofendido pelos meios de comunicação, sob pena de ser este novamente vitimizado com a exposição de fatos relativos à sua esfera de intimidade.

Embora não tenha sido especificamente disciplinada na lei a possibilidade de adoção de idêntico procedimento em relação às testemunhas, temos que o juiz também poderá proibir a captação de sons e imagens relativas a elas para a preservação de sua intimidade, desde que se mostre proporcional (adequada, necessária e proporcional em sentido estrito) a medida, que encontra amparo no artigo 792, caput, e $\S 1^{\circ}$, do Código de Processo Penal, c.c. o artigo 155 do Código de Processo Civil; por aplicação analógica, no referido artigo 201, § $6^{\circ}$, do Código de Processo Penal, visto que, embora possua a testemunha o dever de depor em juízo sobre fatos que sejam de seu conhecimento, não esta ela obrigada a compartilhar com o público dos meios de comunicação de massa os seus segredos mais íntimos; e na ideia, trabalhada no capítulo anterior, de que todos os direitos fundamentais subordinam-se à ponderação por meio do método da proporcionalidade. 
Outra questão que surge diz respeito à possível influência que a presença de câmeras e aparelhos eletrônicos destinados à captação de sons e imagens possa exercer, durante o julgamento, na atuação das demais garantias do processo, notadamente no ânimo das partes, vítimas, testemunhas e julgadores, a ponto de comprometer o resultado justo do processo.

Neste ponto, é realmente possível que a presença ostensiva de diversos jornalistas, com vários microfones, gravadores, holofotes etc. possa de alguma forma, ainda que de difícil mensuração, interferir na autuação das partes e na oitiva de vítimas e testemunhas, causando algum prejuízo às garantias do contraditório e da ampla defesa.

O referido prejuízo não se relaciona, todavia, à possibilidade de ser o julgamento acompanhado pelos meios de comunicação, mas, sim, à forma pela qual se materializa a publicidade.

Ora, o estabelecimento de regras pelo juiz, no exercício de seu poder de polícia das audiências, para a instalação dos aparelhos destinados à captação dos sons e imagens em locais adequados, a proibição de holofotes e a imposição de disciplina aos profissionais da mídia podem eliminar completamente o risco a algum prejuízo a garantias processuais.

Os aspectos acima destacados revelam, contudo, que seria adequada a regulamentação legal da matéria, especialmente com o objetivo de padronização da cobertura dos julgamentos pelos meios de comunicação de massa. 
Critica-se ainda a possibilidade de que a cobertura dos julgamentos possa afetar a imparcialidade dos julgadores, supostamente pressionados a proferir decisão nos moldes pretendidos pela opinião pública, "manipulada" pelos meios de comunicação de massa.

\section{DIEGO FAJARDO MARANHA LEÃO DE SOUZA $\mathrm{e}$} ROSIMEIRE VENTURA LEITE, entre outros autores, ${ }^{279}$ preocupam-se sobremaneira com a possibilidade de ser afetada a imparcialidade dos julgadores pela atuação dos meios de comunicação de massa:

No caso em que se choca o pressuposto da imparcialidade do juiz, a liberdade de imprensa atinge um dos sustentáculos do processo penal sob sistema acusatório. É condição de um julgamento idôneo que o órgão que irá aplicar o direito ao caso concreto esteja alheio a padrões ou posicionamentos, que não sofra interferência de quaisquer das partes ou de origem externa. O que com mais freqüência se tem observado é a tendência de exigência de punição, na linha do movimento de Lei e Ordem, por parte dos meios de comunicação. O que não significa que deixará de haver problema se, eventualmente, postar-se a opinião publicada ao lado de um determinado réu, pugnando por sua absolvição ${ }^{280}$.

${ }^{279}$ GUARIGLIA Fabricio; ROXIN; e GONZALEZ REQUENA, Jesús apud ANITUA, Gabriel Ignacio. El princípio de publicidad... op. cit., p. 95.

${ }^{280}$ LEÃO DE SOUZA, Diego Fajardo Maranha, LEITE, Rosimeire Ventura. O sigilo no processo criminal... op. cit., p. 224. 
Não compartilhamos, todavia, com a referida preocupação, pois, como bem adverte GABRIEL IGNACIO ANITUA, a existência de "interferências externas", ainda que não diretamente relacionadas com o atuar da mídia, no ato de julgar são inevitáveis, inerentes a qualquer atuar público, salvo se concebermos a justiça como um lugar asséptico, livre de valorações, prejuízos e preconceitos ${ }^{281}$.

Cabe ainda ponderar que as "interferências externas" não incidem apenas no instante do julgamento. Com efeito, a cobertura jornalística realizada pela mídia vai muito além disso. Os jornalistas estabelecem contato direto com os protagonistas do fato a ser julgado, bem como apresentam versões, às vezes distorcidas, sobre o crime e seu culpado bem antes do momento do julgamento.

Como já propusemos no presente trabalho, a publicidade do juízo formalizado apresenta-se como o melhor "remédio" para mitigar os efeitos deletérios dos "juízos paralelos".

Segundo ANITUA:

Para impedir que se hagan juicios 'paralelos al institucional em los médios de comunicación, creemos que lo mejor es que los médios transmitam el juicio original, el formalizado. Es preferible uma única version directa que uma segunda (y distinta) version em um estúdio de

${ }^{281}$ ANITUA, Gabriel Ignacio. El princípio de publicidad... op. cit., p. 95. 
televisión donde ninguna de lãs pautas que hacen a uma determinada escenificación llamada 'juicio penal ${ }^{282}$.

No que se refere a uma possível maior vulnerabilidade dos jurados em relação à opinião pública, de se notar que o legislador constitucional preocupou-se em conferir-lhes, no momento do julgamento, maior tranquilidade para a decisão, estabelecendo o voto secreto, e o legislador infraconstitucional estatuiu a "sala especial". Aliás, em recente modificação legislativa (artigo 483 do CPP, com a redação trazida pela Lei n. 11.689/08), determinou-se o encerramento da votação no exato instante em que os jurados manifestarem a sua decisão majoritária, o que realçou a proteção do segredo do voto.

Reiteramos também que a suposta maior suscetibilidade dos jurados à opinião pública também não se veria solucionada com a exclusão da atuação dos meios de comunicação no instante do julgamento, pois que a cobertura jornalística realizada pela crônica policial e judicial inicia-se, em regra, muito antes do momento do julgamento.

Convém ademais lembrar que o exercício da liberdade de informar nos julgamentos cujos sons e imagens são transmitidos ou reproduzidos ao público pelos meios de comunicação de massa limita-se, logicamente, pelo princípio da verdade, daí se concluindo que o exercício responsável da aludida liberdade impõe a divulgação ou a reprodução integral ou resumida do julgamento, sem a edição tendenciosa da matéria, sob pena de responsabilização dos autores do desvio.

${ }^{282}$ ANITUA, Gabriel Ignacio. El princípio de publicidad... op. cit., p. 99. 
A propósito, dispõe o artigo 27 da Lei n. 5.250/67, o qual ainda se encontra em vigor, que não constitui abuso no exercício da liberdade de manifestação do pensamento e de informação:

(...) IV - a reprodução integral, parcial ou abreviada, a notícia, crônica ou resenha dos debates escritos ou orais, perante juízes e tribunais, bem como a divulgação de despachos e sentenças e de tudo quanto for ordenado ou comunicado por autoridades judiciais.

\section{Assevera DARCY ARRUDA MIRANDA:}

É livre, portanto, a crônica judiciária, desde que não refuja aos lindes estabelecidos pela verdade, condicionada ao interesse social. Se descai do animus narrandi, na apreciação moderada e correta dos fatos, para o dolo, juntando ao relato um condimento pessoal de malignidade, o fato deriva para a esfera delituosa ${ }^{283}$.

Impende ainda assinalar que, não sendo a publicidade um valor absoluto, é inevitável o surgimento de várias outras situações em que se mostrará necessária a restrição do acompanhamento pela mídia de atos processuais, cabendo mencionar, por exemplo, as hipóteses de proteção de vítimas e testemunhas ameaçadas previstas na Lei n. 9.807/99, que impõem a

${ }^{283}$ MIRANDA, Darcy Arruda. Comentários..., op. cit., p. 544. 
preservação da identidade, imagem e dados pessoais (artigo $6^{\circ}$, inciso IV, da Lei n. 9.807/99).

As referidas hipóteses, inserindo-se na categoria de limitação à publicidade em virtude do interesse social, abrangem valores de maior "peso" que o da publicidade, como a vida, a segurança e a integridade física das vítimas e testemunhas, os quais, por ocasião de uma análise de proporcionalidade, certamente se sobreporiam à publicidade.

Em suma, a publicidade não representa solução milagrosa para todos os problemas do processo penal, das Polícias, do Ministério Público e do Poder Judiciário, mas, por envolver toda a comunidade nos assuntos relacionados às infrações penais cometidas em seu seio e à apuração destas pelos órgãos envolvidos na persecução penal, pode, além de contribuir para que se conheça melhor o funcionamento de tais órgãos, legitimando a atuação destes, e se disseminem os valores abrangidos pelos direitos fundamentais, violados pelo autor de uma infração penal, propiciar o debate democrático para a melhoria do sistema processual penal. 


\section{9- CONCLUSÕES:}

A garantia da publicidade constitui um dos princípios fundamentais do processo penal no Estado Democrático de Direito, seja como garantia política de que o poder jurisdicional somente será exercido por intermédio de uma persecução penal transparente, na qual a fiscalização ex parte populi preserva o indivíduo contra o arbítrio Estatal, propiciando ainda a verificação sobre a regularidade das posturas adotadas no procedimento e a observância das demais garantias processuais: imparcialidade do julgador, contraditório, ampla defesa, legalidade e motivação das decisões, seja conferindo legitimidade à decisão proferida no processo, o que se mostra imprescindível ao exercício do poder no Estado Democrático de Direito, especialmente no que se refere às funções afetas aos órgãos incumbidos da persecução penal e ao Poder Judiciário, que, em regra, não são desempenhadas por agentes escolhidos mediante intervenção popular, seja como garantia na persecução penal, viabilizando a atuação de outras garantias, por intermédio do acesso irrestrito às partes, procuradores e juiz a todas as informações constantes dos autos, assim propiciando sobretudo um contraditório pleno e o exercício da ampla defesa.

A publicidade possui importância histórica, também representando grande valor no plano da tutela internacional dos direitos humanos, mas a evolução dos meios tecnológicos, possibilitando a difusão quase imediata de informações, notadamente por intermédio de novos equipamentos - computadores, câmeras, telefones celulares de última geração etc. -, e a inserção social cada vez maior dos meios de comunicação demandam nova análise da garantia, notadamente para que sejam reavaliadas eventuais colisões com outros direitos fundamentais, em especial com os direitos à intimidade e à vida privada dos cidadãos. 
A publicidade externa compreende a possibilidade de serem os atos processuais acessados pelo público em geral, que pode sofrer restrições decorrentes da necessidade de serem tutelados outros valores igualmente relevantes.

A publicidade interna refere-se ao direito que partes, procuradores e julgador possuem de terem conhecimento integral sobre o conteúdo do processo, abrangendo a prévia ciência dos atos a serem praticados, presença física nos atos de que participem e intimação dos atos realizados sem sua direta participação.

O sigilo constitui o mecanismo por meio do qual o segredo é protegido.

A publicidade encontra-se disciplinada na Constituição Federal Brasileira nos artigos $5^{\circ}$, inciso LX, e 93, inciso IX, representando relevante finalidade a ser perseguida, somente passível de limitação, por intermédio de lei, para a tutela do interesse social e da intimidade.

Diplomas internacionais que também fazem parte do ordenamento jurídico nacional também autorizam a limitação no interesse da justiça.

A norma da publicidade também se aplica aos procedimentos de investigação criminal, seja como decorrência do princípio do devido processo legal, seja em razão de sua expressa previsão na disciplina constitucional da administração pública, mas comporta restrições pontuais. 
A publicidade, na fase processual, é mais ampla do que na etapa da investigação, mas também comporta, em poucos casos, limitações.

A publicidade possui a dimensão de regra, princípio e postulado.

A regra da publicidade condiciona a validade de sua restrição à observância de um procedimento determinado que resulte na aprovação de uma lei, vedando ainda o estabelecimento de limitações que não se refiram à tutela da intimidade e do interesse processual.

O princípio da publicidade estabelece como devida a realização do valor publicidade, seja na sua função de garantia política de fiscalização pelo público do exercício do poder jurisdicional e das atividades a ele relacionadas, seja na sua função de garantia processual.

O postulado da publicidade restringe a interpretação e a aplicação da publicidade e de suas limitações à lei e ao Direito, vedando a utilização de parâmetros alheios ao ordenamento jurídico.

A publicidade, ainda que consideradas as suas distintas dimensões normativas, admite ponderação, pela aplicação do postulado da proporcionalidade, para a solução de questões envolvendo a colisão do direito fundamental publicidade com outros direitos fundamentais.

O postulado da proporcionalidade constitui método de interpretação e aplicação das normas, que decorre logicamente do sistema 
constitucional de tutela dos direitos fundamentais, utilizado para a solução de conflitos entre direitos fundamentais, compreendendo o exame da adequação, da necessidade e da proporcionalidade em sentido estrito da promoção de um direito fundamental em detrimento de outro.

A personalidade do ser humano projeta-se em três esferas distintas.

A esfera da intimidade consubstancia-se em área nuclear inviolável, propiciando o livre desenvolvimento da personalidade. Relaciona-se a aspectos da vida do indivíduo que somente se referem e interessam a ele próprio, dizendo com o modo de ser da pessoa e com o seu direito de estar só, de maneira que não comporta restrições com base em ponderações realizadas por meio do postulado da proporcionalidade.

Já a privacidade estrito senso abrange os atos da vida da pessoa que se relacionam ao seu círculo mais restrito de relacionamento, no âmbito familiar e profissional.

A esfera do público, por seu turno, refere-se aos atos do indivíduo no âmbito da coletividade, em relação aos quais a pessoa não pretende segredo, não se encontrando, pois, no âmbito de proteção que a intimidade e a privacidade demandam.

As esferas da privacidade e do público admitem ponderações com outros direitos fundamentais. 
A liberdade de expressão compreende as liberdades de manifestações de pensamento, de opinião, de juízo de valor, de consciência, de crença, de ideia, artísticas, científicas e culturais.

A liberdade de comunicação abrange a liberdade de informação, termo mais utilizado em documentos internacionais, em todas as suas dimensões: direito de informar, direito de ser informado (ao qual corresponde um dever de informar), numa perspectiva subjetiva, e o direito à informação, no âmbito da coletividade. A referida liberdade possui fundamental importância nas democracias contemporâneas, sendo amplamente prestigiada no plano da tutela internacional dos direitos fundamentais e na Constituição Federal Brasileira.

A liberdade de informação possui, contudo, limites. A verdade constitui uma limitação lógica. Outros direitos fundamentais, de índole pessoal e de natureza processual, também podem representar limites à liberdade de informação.

A publicidade externa das investigações criminais pode ser restringida para evitar o comprometimento de garantias processuais e do resultado justo do processo.

A publicidade na fase do processo autoriza, em princípio, a divulgação e a reprodução, pelos meios de comunicação de massa, de sons e imagens dos julgamentos, tendo em vista as finalidades do processo e da própria publicidade. 
A publicidade, nas sociedades contemporâneas, é finalidade que somente se realiza com a atuação dos meios de comunicação de massa.

A publicidade processual possui poucas restrições, que se comunicam aos meios de comunicação de massa, entre as quais merecem destaque a proteção da intimidade e da segurança do ofendido e de testemunhas, hipótese em que se revela proporcional a limitação da garantia.

A publicidade processual constitui a melhor solução para mitigar os efeitos deletérios dos "julgamentos paralelos".

A publicidade processual veiculada pelos meios de comunicação de massa não representa sério risco à imparcialidade do julgador, pois a justiça não constitui um ambiente asséptico para a tomada de decisões, sendo inevitável a existência de influências externas ao processo no julgamento.

A publicidade processual veiculada pelos meios de comunicação de massa, além de contribuir para que se conheça melhor o funcionamento dos órgãos incumbidos da persecução, legitimando a atuação destes, e se disseminem os valores abrangidos pelos direitos fundamentais, violados pelo autor de uma infração penal, pode propiciar o debate democrático para a melhoria do sistema processual penal. 


\section{0 - BIBLIOGRAFIA:}

ABADE, Denise Neves. Direito de acesso aos autos no processo penal: breve análise crítica, in: RBCCRIM 57, p. 121-158.

AFOnso DA SILVA, José. Curso de Direito Constitucional Positivo. 30 . ed. São Paulo, Malheiros, 2008, p. 516.

ALMEIDA JÚNIOR, João Mendes de. O Processo Criminal Brasileiro, vol. I, 3. ed. Rio de Janeiro: Baptista de Souza, 1920.

ANDRADE KEHDI, André Pires. O sigilo da ação penal - Aspectos gerais. In: Sigilo no Processo Penal - Eficiência e Garantismo. Vários autores, sob a coordenação de Antonio Scarance Fernandes, José Raul Gavião de Almeida e Maurício Zanoide de Moraes. São Paulo: RT, 2008, p. 57-95.

ANITUA, Gabriel Ignacio. El principio de publicidad procesal penal: um análisis com base em La historia y el derecho comparado, in: Las garantias penales y procesales: Enfoque histórico-comparado, Edmundo S. Hendler (comp.), Buenos Aires: Editores Del Puerto, 2001, p. 67-102.

ALEXY, Robert. Teoria dos Direitos Fundamentais, 5. ed. alemã. Tradução de Virgílio Afonso da Silva. São Paulo: Malheiros, 2008.

ARAÚJO CINTRA, Antonio Carlos de; GRINOVER, Ada Pellegrini; e DINAMARCO, Cândido Rangel. Teoria Geral do Processo. 12. Ed. São Paulo: Malheiros, 1996.

ARAÚJO DA SILVA, Eduardo. Crime Organizado: Procedimento probatório. São Paulo: Atlas, 2003.

ASSIS MOURA, Maria Thereza Rocha de. A prova por indícios no processo penal. São Paulo: Saraiva, 1994.

ÁVILA, Humberto. Teoria dos Princípios: Da definição dos princípios. São Paulo: Malheiros, $7^{\mathrm{a}}$ ed., 2007.

BADARÓ, Gustavo Henrique Righi Ivahy. Ônus da Prova no Processo Penal. São Paulo: RT, 2003.

; GALLUZI DOS SANTOS,

Leandro; GOMES FILHO, Antonio Magalhães; PRADO Geraldo; BOTTINI, Pierpaolo Cruz, As Reformas no Processo Penal: As novas Leis de 2008 e os Projetos de Reforma. Coordenado por Maria Thereza Rocha de Assis Moura. São Paulo: RT, 2008. 
BAndeIRA De MELlo, Celso Antônio. Curso de Direito Administrativo. 11. ed. São Paulo: Malheiros, 1999

BARROS, Marco Antonio de. Lavagem de capitais e obrigações civis correlatas. São Paulo: RT, 2004.

BASTOS, Celso Ribeiro. A Liberdade de Expressão e a Comunicação Social. In: Revista dos Tribunais - Cadernos de Direito Constitucional e Ciência Política n. 20, julho-setembro de 1997, p. 48-52.

. Os Limites à Liberdade de Expressão na

Constituição da República. Revista Forense, janeiro-fevereiro-março 2000, p. $43-51$.

BInenbojM, Gustavo. Meios de Comunicação de Massa: Pluralismo e Democracia Deliberativa - As liberdades de expressão e de imprensa nos Estados Unidos e no Brasil. Direitos Fundamentais: Estudos em homenagem ao Professor Ricardo Lobo Torres, organizado por Daniel Sarmento e Flavio Galdino. Rio de Janeiro - São Paulo - Recife, 2006, p. 473-97.

BOBBIO, Norberto. A era dos direitos. 5. ed. Rio de Janeiro: Elsevier, , 2004.

BONFIM, Edílson Mougenot. No Tribunal do Júri. São Paulo: Saraiva, 2000.

BOSCHI, Marcus Vinicius. Publicidade e segredo dos atos processuais: (des)respeito às garantias fundamentais do acusado, in Revista Iberoamericana de Ciências Penais n. 3, Porto Alegre: 2001.

BOTTINI, Pierpaolo Cruz; GALLUZI DOS SANTOS; Leandro, GOMES FILHO; Antonio Magalhães; PRADO Geraldo; BADARÓ, Gustavo Henrique Righi Ivahy; As Reformas no Processo Penal: As novas Leis de 2008 e os Projetos de Reforma. Coordenado por Maria Thereza Rocha de Assis Moura. São Paulo: RT, 2008.

BUENO DE GODOY, Claudio Luiz. A Liberdade de Imprensa e os Direitos da Personalidade. São Paulo: Atlas, 2001.

CABRAL SARAIVA, Wellington. A Regra do Segredo nas ações penais do Tribunal de Justiça do Distrito Federal: Inconstitucionalidade, in: Boletim dos Procuradores da República n. 27, julho de 2000, p. 28-29.

COBO DEL ROSAL, Manuel. Lo inverossimil de los juicios paralelos. In Quisicosas de los delitos y delas penas. Madrid: CESEJ, 2005.

COSTA ANDRADE, Manuel da. Liberdade de Imprensa e Inviolabilidade Pessoal: Uma Perspectiva Jurídico-Criminal. Coimbra: Coimbra Editora, 1996. 
COSTA GARCIA, Guiomar Garson da. Estado Democrático de Direito e Liberdade de Expressão e Informação.In: Revista de Direito Constitucional e Internacional, janeiro-março 2003, p. 258-98.

COSTA JÚNIOR, Paulo José. O direito de estar só: tutela penal da intimidade. São Paulo, RT, 1970.

DENTI, Vittorio. Evoluzione del diritto delle prove nei processi civili contemporanei, p. 31-69.

DINAMARCO, Cândido Rangel; ARAÚJO CINTRA, Antonio Carlos de; e GRINOVER, Ada Pellegrini. Teoria Geral do Processo. 12. ed. São Paulo: Malheiros, 1996.

DONNINI, Oduvaldo; DONNINI, Rogério Ferrar. Imprensa Livre: Dano Moral, Dano à Imagem, e sua quantificação à luz do novo Código Civil. São Paulo: Método, 2002.

FARIAS, Edilsom. Liberdade de Expressão e Comunicação - Teoria e Proteção Constitucional. São Paulo: RT, 2004.

- Democracia, censura e liberdade de expressão e

informação na Constituição Federal. Disponível em:
$<$ http://jus2.uol.com.br/doutrina/texto.asp?id=2195 $>$. Consultado em 05-102007.

FERRAJOLI, Luigi. Direito e Razão: Teoria do Garantismo Penal, 2. ed. São Paulo: RT, 2006.

FIGUeiredo DiAS, Jorge de. Direito Processual Penal. Coimbra: Coimbra Ed., 1974, reimpressa em 2004.

GALLUZI DOS SANTOS, Leandro; GOMES FILHO, Antonio Magalhães; PRADO, Geraldo; BADARÓ, Gustavo Henrique Righi Ivahy; BOTTINI, Pierpaolo Cruz. As Reformas no Processo Penal: As novas Leis de 2008 e os Projetos de Reforma. Coordenado por Maria Thereza Rocha de Assis Moura. São Paulo: RT, 2008.

GOMes FILHO, Antonio Magalhães. Direito à Prova no Processo Penal. São Paulo, RT, 1997.

Paulo: RT, 2001

A motivação das decisões penais. São ; PRADO, Geraldo; GALLUZI DOS SANTOS, Leandro; BADARÓ, Gustavo Henrique Righi Ivahy; BOTTINI, Pierpaolo Cruz. As Reformas no Processo Penal: As novas Leis de 2008 e os Projetos de Reforma. Coordenado por Maria Thereza Rocha de Assis Moura. São Paulo: RT, 2008. 
GRINOVER, Ada Pellegrini; SCARANCE FERNANDES, Antonio. As nulidades no processo penal. 3. ed. São Paulo: Malheiros, 1994.

GONZÁLEZ GARCÍA, Jesús María. Entre el derecho de defensa y el derecho a La información: viejas e nuevas cuestiones sobre La publicidad de lãs actuaciones del proceso penal. In: Revista Del Poder Judicial, n. 80, cuarto trimestre 2005.

GRINOVER, Ada Pellegrini. Os Princípios Constitucionais e o Código de Processo Civil. São Paulo: Bushatsky, 1975.

; SCARANCE FERNANDES, Antonio; GOMES FILHO, Antonio Magalhães. As nulidades no processo penal. 3. ed. São Paulo: Malheiros, 1994.

; ARAÚJO CINTRA, Antonio Carlos de; e DINAMARCO, Cândido Rangel. Teoria Geral do Processo. 12. ed. São Paulo: Malheiros, 1996.

GRECO FILHO, Vicente. Interceptação telefônica: Considerações sobre a Lei n. 9.296, de 24 de julho de 1996. São Paulo: Saraiva, 1996.

1996.

Manual de processo penal. São Paulo: Saraiva,

Saraiva, 1989.

. Tutela constitucional das liberdades. São Paulo,

HUNGRIA, Nelson. Comentários ao Código Penal. Vol. 5. Rio de Janeiro: Forense.

LACAVA, Thaís Aroca Datcho. O sigilo nas Comissões Parlamentares de Inquérito e as garantias individuais. In: Sigilo no Processo Penal Eficiência e Garantismo. Vários autores, coordenada por ANTONIO SCARANCE FERNANDES, JOSÉ RAUL GAVIÃO DE ALMEIDA $\mathrm{e}$ MAURÍCIO ZANOIDE DE MORAES. São Paulo: RT, 2008, p. 115-137.

LAFER, Celso. A reconstrução dos direitos humanos: um diálogo com o pensamento de Hannah Arendt. 6. ed. São Paulo: Companhia das Letras, , 2006.

O moderno e o antigo conceito de liberdade, in: Ensaios sobre a liberdade. São Paulo: Perspectiva, 1980, p. 11-48.

LEÃO DE SOUZA, Diego Fajardo Maranha; LEITE, Rosimeire Ventura. O sigilo no processo criminal e o interesse público à informação. In: Sigilo no Processo Penal - Eficiência e Garantismo. Vários autores, sob a coordenação 
de Antonio Scarance Fernandes, José Raul Gavião de Almeida e Maurício Zanoide de Moraes. São Paulo: RT, 2008, p. 203-238.

LEITE, Rosimeire Ventura; LEÃO DE SOUZA, Diego Fajardo Maranha. O sigilo no processo criminal e o interesse público à informação. In: Sigilo no Processo Penal - Eficiência e Garantismo. Vários autores, sob a coordenação de Antonio Scarance Fernandes, José Raul Gavião de Almeida e Maurício Zanoide de Moraes. São Paulo: RT, 2008, p. 203-238.

LEMOS, Tayara Talita. A Emenda Constitucional 45/04 e as Alterações na Recepção dos Tratados Internacionais de Direitos Humanos. Centro de Direito Internacional. Revista Eletrônica de Direito Internacional, 2007. Disponível em: < $\underline{w w w . c e d i n . c o m . b r / r e v e l e t r o n i c a ~}>$, acessado em 07 de janeiro de 2009.

LOPEZ LOPEZ, Alberto Manuel. Publicidad, indefension y tutela judicial efectiva. In: Atualidad Penal n. 2, Madrid: Actualidad Editorial, 1993, p. 375 386.

Magalhães noronha, E.. Curso de Processo Penal. 19. ed. São Paulo: Saraiva, 1989.

MARQUES, José Frederico. Elementos de Direito Processual Penal. 2. ed. Campinas-SP: Millennium, 2000.

A instituição do Júri. São Paulo: Saraiva, 1963.

MARQUES PORTO, Hermínio Alberto. Júri - Procedimentos e aspectos do julgamento - Questionários. 9. ed. São Paulo, Malheiros, 1998

MIRANDA, Darcy Arruda. Comentários à Lei de Imprensa. São Paulo: RT, 1969.

Menezes VieirA, Ana Lúcia. Processo Penal e Mídia. São Paulo: RT, 2003.

MORAES, Alexandre de. Direito Constitucional. 20. ed. São Paulo: Atlas.

NOBRE, Freitas. Comentários à Lei de Imprensa. São Paulo: Saraiva, 1978.

NUVOlone, Pietro. Il Dirito Penale della Stampa. Padova: Cedam, 1971.

PACHECO, Denílson Feitoza. O princípio da proporcionalidade no Direito Processual Penal Brasileiro. Rio de Janeiro: Lúmen Júris, 2007.

PRADO, Geraldo; GALLUZI DOS SANTOS, Leandro; GOMES FILHO, Antonio Magalhães; BADARÓ, Gustavo Henrique Righi Ivahy; BOTTINI, Pierpaolo Cruz. As Reformas no Processo Penal: As novas Leis de 2008 e os Projetos de Reforma. Coordenado por Maria Thereza Rocha de Assis Moura. São Paulo: RT, 2008. 
RAHAL, Flávia. A publicidade no processo penal brasileiro - Confronto com o direito à intimidade. Dissertação de mestrado em Direito Processual Penal apresentada na Universidade de São Paulo, no ano 2000.

RBCCRIM 47, ano 2004, p. 270-283.

Publicidade no processo penal: a mídia e o processo, in:

SAAD, Marta. O Direito de Defesa no Inquérito Policial. São Paulo: Revista dos Tribunais, 2004

SAMPAIO FERRAZ JÚNIOR, Tércio. Liberdade de Informação e Privacidade ou o Paradoxo da Liberdade. In: O Cinqüentenário da Declaração Universal dos Direitos do Homem, organizado por Alberto do Amaral Júnior e Cláudia Perrone-Moisés. São Paulo: Edusp, 1999, p. 385-93.

SCARAnCE FERnANDES, Antonio, Processo Penal Constitucional, São Paulo: RT, 2005.

Reflexões sobre as noções de eficiência e garantismo no processo penal. In: Sigilo no Processo Penal: Eficiência e Garantismo. Vários autores, sob a coordenação de Antonio Scarance Fernandes, José Raul Gavião de Almeida e Maurício Zanoide de Moraes. São Paulo: RT, 2008, p. 09-28.

; GRINOVER, Ada Pellegrini; GOMES FILHO, Antonio Magalhães. As nulidades no processo penal. 3. ed. São Paulo: Malheiros, 1994.

SERRANO NUNES JÚNIOR, Vidal. O Direito de Informação e a Concorrência de Direitos Fundamentais. In: A Proteção Constitucional da Informação e o Direito à Crítica Jornalística, coordenado por Hélio Bicudo, São Paulo: FTD, 2001, p. 24-33.

SLAIBI FILHO, Nagib. A publicidade no processo judicial (notas sobre a nova redação do art. 93, IX, da Constituição), in: Revista de Direito do Tribunal de Justiça do Estado do Rio de Janeiro n. 63, abril/junho de 2005, p. 381-386.

SOUZA LIMA, Carolina Alves de. Aborto e Anencefalia: Direitos fundamentais em colisão. Curitiba: Juruá, 2008.

TARUFFO, Michele. La prova dei fatti giuridici. Milano: Giuffrè, 1992, p. 400-409.

TOLEDO BARROS, Suzana de. O princípio da proporcionalidade e o controle de constitucionalidade das leis restritivas de direitos fundamentais. 2. ed. Brasília: Brasília Jurídica, 2000. 
TORnaGHI, Helio. Manual de Processo penal. Rio de Janeiro: 1963.

TOURINHO FILHO, Fernando da Costa. Processo Penal 1. 28. ed. São Paulo, Saraiva, 2006.

TUCCI, Rogério Lauria. Ministério Público e Investigação Criminal. São Paulo: RT, 2004.

Direitos e garantias individuais no processo penal brasileiro. 2. ed. São Paulo: RT, 2004.

UBERTIS, La ricerca della verità giudiziale, in: La conoscenza del fatto nel processo penale, a cura di Giulio Ubertis. Milano: Giuffrè, 1992, p. 09-16.

ZANOIDE DE MORAES, Maurício. Publicidade e proporcionalidade na persecução penal brasileira. In: Sigilo no Processo Penal: Eficiência e Garantismo. Vários autores, sob a coordenação de Antonio Scarance Fernandes, José Raul Gavião de Almeida e Maurício Zanoide de Moraes. São Paulo: RT, 2008, p. 29-55. 


\section{RESUMO:}

A garantia da publicidade nas investigações criminais e no processo penal constitui um dos princípios fundamentais do processo penal no Estado Democrático de Direito. Representa, de um lado, garantia política de que o poder jurisdicional somente será exercido por intermédio de uma persecução penal transparente, na qual a fiscalização ex parte populi preserva o indivíduo contra o arbítrio Estatal, propiciando ainda a verificação sobre a regularidade das posturas adotadas no procedimento e a observância das demais garantias processuais: imparcialidade do julgador, contraditório, ampla defesa, legalidade e motivação das decisões. A publicidade, vista sob tal aspecto, confere legitimidade à decisão proferida no processo, o que se mostra imprescindível ao exercício do poder no Estado Democrático de Direito, especialmente no que se refere às funções afetas aos órgãos incumbidos da persecução penal e ao Poder Judiciário, que, em regra, não são desempenhadas por agentes escolhidos mediante intervenção popular. De outro lado, a publicidade também exerce o papel de garantia na persecução penal, viabilizando a atuação de outras garantias, por intermédio do acesso irrestrito às partes, procuradores e juiz a todas as informações constantes dos autos, assim propiciando sobretudo um contraditório pleno e o exercício da ampla defesa. É certo, outrossim, que o tema da publicidade na persecução vem, nos dias atuais, ganhando especial relevância. Com efeito, a evolução dos meios tecnológicos, propiciando a difusão quase imediata de informações, notadamente por intermédio de novos equipamentos - computadores, câmeras, telefones celulares de última geração etc. -, e a inserção social cada vez maior dos meios de comunicação constituem um sério risco aos direitos fundamentais, especialmente à intimidade e vida privada dos cidadãos. E o confronto entre a liberdade de expressão e a intimidade pode emergir no curso da persecução penal, relacionando-se ainda com a publicidade desta. . Como se vê, não bastasse a importância histórica, como conquista democrática do processo, do princípio da publicidade, faz-se atualmente necessária a sua releitura, à luz de 
uma nova realidade social, na qual os direitos fundamentais e o próprio Estado Democrático de Direito veem-se ameaçados pelo avanço indevido da coletividade na esfera do indivíduo. Avaliar se existe ou não a possibilidade de ser a publicidade processual restringida, e em que medida, para a preservação da intimidade e da vida privada, atualmente mais ameaçadas pelo avanço dos meios tecnológicos e da grande inserção social dos meios de comunicação, que por vezes fazem do processo um "espetáculo", é o objetivo deste estudo. 


\section{1 - RIASSUNTO:}

La garanzia di pubblicità nelle indagini penali e nel processo penale costituisce uno dei principi fondamentali del processo penale nello Stato Democratico di Diritto. Rappresenta da un lato garanzia politica che il potere giurisdizionale solo sarà esercitato attraverso una persecuzione penale trasparente, nella quale il controllo parte populis preserva l'individuo nei confronti dell'arbitrio Statale, permettendo inoltre la verifica sulla regolarità dei comportamenti adottati nel procedimento e il rispetto delle altre garanzie processuali: imparzialità dell'organo giudicante, contraddittorio, ampia difesa, legalità e motivazione delle decisioni.

La pubblicità, vista sotto quest'aspetto, conferisce legittimità alla decisone emessa nel processo, la qual cosa risulta imprescindibile all'esercizio del potere nello Stato Democratico di Diritto, specialmente per quel che riguarda le funzioni attribuite agli organi incaricati della persecuzione penale e al Potere Giudiziario, i quali, generalmente, non sono svolte da agenti scelti mediante suffragio popolare.

D'altro canto, la pubblicità pure esercita il ruolo di garanzia nella persecuzione penale, rendendo possibile l'applicazione di altre garanzie, attraverso l'accesso completo delle parti, pubblico ministero e giudici, a tutte le informazioni costanti dagli atti, in tal modo favorendo soprattutto il pieno contraddittorio e l'esercizio dell'ampia difesa.

È certo, inoltre, che il tema della pubblicità nella persecuzione, va acquistando, ai giorni nostri, rilievo speciale. Effettivamente, lo sviluppo dei mezzi tecnologici, permettendo la diffusione quasi immediata delle informazioni, specialmente per mezzo delle nuove attrezzature - 
computers, camere televisive, telefoni cellulari di ultima generazione, ecc. - e l'inserimento sociale sempre maggiore dei mezzi di comunicazione, costituiscono un serio rischio per $\mathrm{i}$ diritti fondamentali, specialmente all'intimità e alla vita privata dei cittadini.

E il contrasto tra la libertà di espressione e l'intimità può emergere nel corso della persecuzione penale, riguardando inoltre la pubblicità di essa. Come si vede, non bastasse l'importanza storica, come conquista democratica del processo, del principio della pubblicità, si rende oggi necessaria una sua rilettura, alla luce della nuova realtà sociale, nella quale i diritti fondamentali e lo stesso Stato Democratico di Diritto si vedono minacciati dall'indebita invasione della collettività nella sfera dell'individuo.

Valutare se esiste o no la possibilità che la pubblicità processuale venga ristretta, e in che misura, per la preservazione dell'intimità e della vita privata, attualmente maggiormente minacciate per il progresso dei mezzi tecnologici e del grande inserimento sociale dei mezzi di comunicazione, che alle volte fanno del processo uno "spettacolo", è lo scopo di questo studio. 